\title{
The Effect of Early Skin-to-Skin Contact on Breastfeeding Duration and Exclusivity: a Mixed Methods Study
}

\author{
Cristina Menking-Hoggatt
}

Follow this and additional works at: https://researchrepository.wvu.edu/etd

\section{Recommended Citation}

Menking-Hoggatt, Cristina, "The Effect of Early Skin-to-Skin Contact on Breastfeeding Duration and Exclusivity: a Mixed Methods Study" (2017). Graduate Theses, Dissertations, and Problem Reports. 6216. https://researchrepository.wvu.edu/etd/6216

This Dissertation is protected by copyright and/or related rights. It has been brought to you by the The Research Repository @ WVU with permission from the rights-holder(s). You are free to use this Dissertation in any way that is permitted by the copyright and related rights legislation that applies to your use. For other uses you must obtain permission from the rights-holder(s) directly, unless additional rights are indicated by a Creative Commons license in the record and/ or on the work itself. This Dissertation has been accepted for inclusion in WVU Graduate Theses, Dissertations, and Problem Reports collection by an authorized administrator of The Research Repository @ WVU.

For more information, please contact researchrepository@mail.wvu.edu. 
The Effect of Early Skin-to-Skin Contact on Breastfeeding

Duration and Exclusivity: a Mixed Methods Study

Cristina Menking-Hoggatt, MS, APRN-CNM

Doctoral Capstone Project submitted to the

School of Nursing at West Virginia University

In partial fulfillment of the requirements for the degree of

Doctor of Nursing Practice

\author{
Susan McCrone, PhD, RN, Chair \\ Martha Summers, DNP, APRN \\ Veneta Eggleton, DNP, PPCNP-BC \\ Charlita Atha, BSN, RN, IBCLC
}

Department of Nursing

Morgantown, West Virginia

2017

Keywords: exclusive breastfeeding, fulltime breastfeeding, skin-to-skin contact, kangaroo care.

Copyright 2017 Cristina Menking-Hoggatt 


\section{ABSTRACT \\ The Effect of Early Skin-to-Skin Contact on Breastfeeding \\ Cristina Menking-Hoggatt}

Background: Breastfeeding is beneficial to the health of both mother and infant and fosters optimal growth for the baby in the first two years of life. Evidence based guidelines followed by the Baby Friendly Hospital Initiative (BFHI) includes Ten Steps. Step Four recommends placing the newborn skin-to-skin on the mother's chest to foster the initiation of breastfeeding in the first hour after birth.

Objectives: The first and second objective determined if skin-to-skin contact (SSC) between mother and infant in the healthy postpartum breastfeeding mother affected duration and exclusivity rates at 6 weeks, 3 months and 6 months. The third objective described mothers' lived experience with breastfeeding and bonding following SSC per policy.

Design: A retrospective, cohort, mixed methods design was used in a small rural hospital in West Virginia (WV). The sample included 55 women who met the inclusion criteria of healthy mothers whose babies were vaginally delivered January 2012 - September 2016. The intervention cohort received SSC per the Baby Friendly Step 4 policy. The comparison group did not receive SSC.

Methods: Duration rates, exclusive breastfeeding (EBF) rates, and mothers' lived experience following SSC were collected via phone interview and transcription.

Results: Comparing the SSC to the comparison cohort, breastfeeding duration rates were: $82.4 \%$ vs. $61.6 \%$ at 6 weeks $($ p. $=0.170) ; 73.5 \%$ vs. $52.4 \%$ at 3 months $($ p. $=0.190) ; 44.1 \%$ versus $42.9 \%$ at 6 months $(\mathrm{p} .=0.170)$. EBF rates were: $73.5 \%$ vs. $51.7 \%$ at 6 weeks $(\mathrm{p}=$ $0.336) ; 64.7 \%$ vs. $52.4 \%$ at 3 months ( $=0.533) ; 20.6 \%$ vs. $23.8 \%$ at 6 months (p. $=1.00)$. In most time intervals the SSC cohort rates were higher than the comparative cohort rates, yet none of the rates reached significance. Mothers identified that SSC had a positive effect on their breastfeeding and bonding experience in the first months of their babies' lives. 
SKIN-TO-SKIN CONTACT: A MIXED METHODS STUDY

Acknowledgements

To my devoted and cherished husband, who shares a devotion to excellence in serving humanity, nursing and family health. He is a brilliant man of many talents who I will always admire.

To my Chairperson, Dr. Susan McCrone, and Capstone Committee Members: Dr. Martha Summers, Dr. Veneta Eggleton, and Charlita Atha, IBCLC who have shared their expertise, time and encouragement with me as needed. Their devotion to excellence in professional nursing is an inspiration.

To the Mother/Baby Unit Manager at the rural hospital, in Lewis county West Virginia, who is an exemplary nurse leader and truly cares about excellence in professional nursing.

Also, to our dear and precious children, who are now adults, to my parents, who have taught me so much about loving and understanding the journey of life and parenthood, and to the generous hearted mothers who shared their own parenting journey and breastfeeding experiences. I offer my deepest gratitude. 
Table of Contents iv

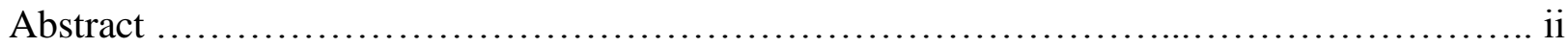

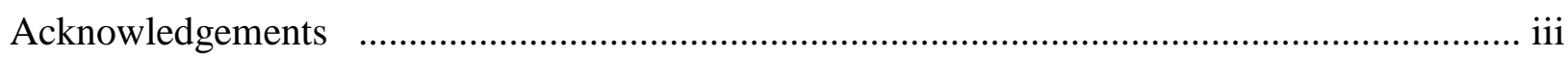

\section{Introduction}

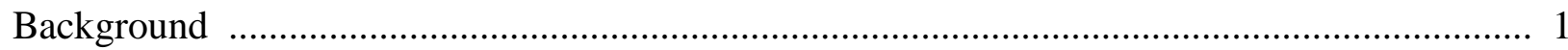

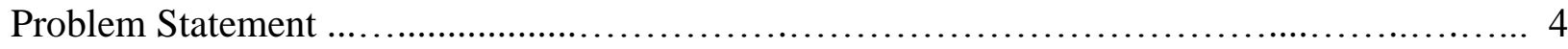

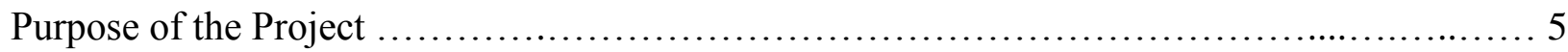

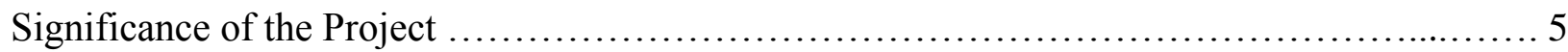

\section{Literature Review}

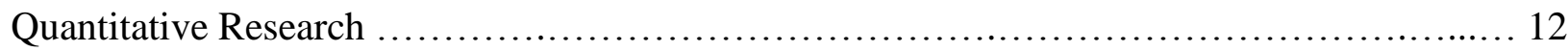

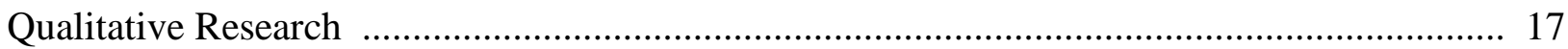

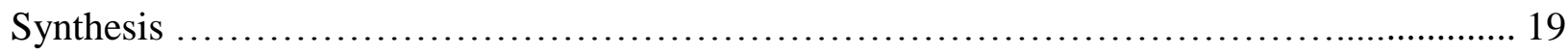

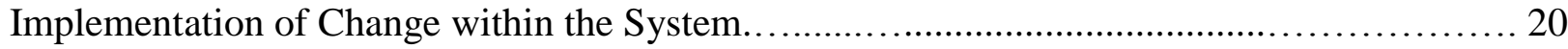

\section{Methodology}

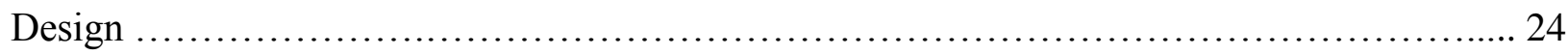

Needs Assessment and Feasibility Analysis ............................................... 25

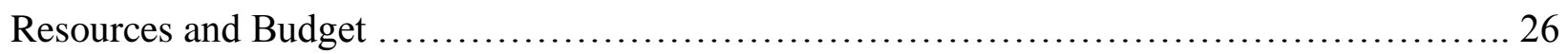

\section{Results}

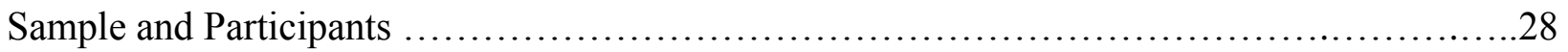

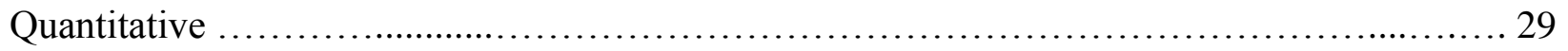

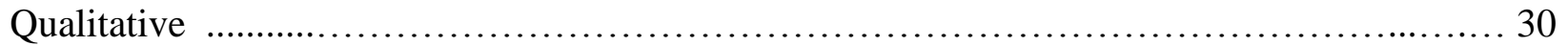

Key Facilitators and Barriers.............................................................

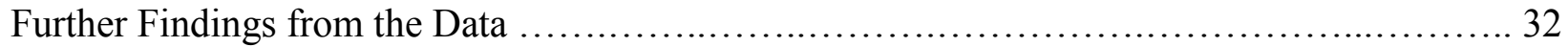




\section{Discussion and Recommendations}

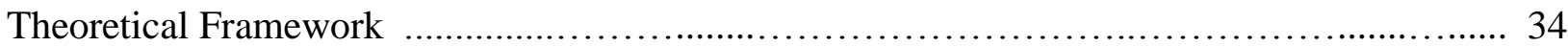

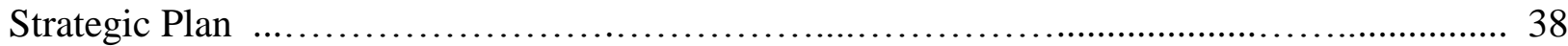

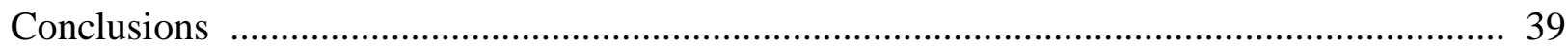

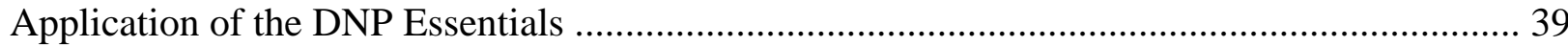

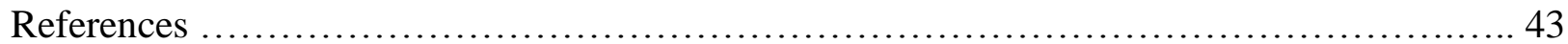

\section{Appendices}

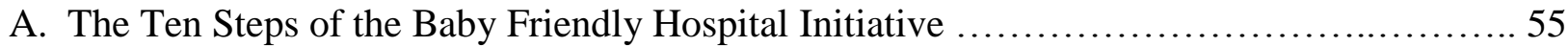

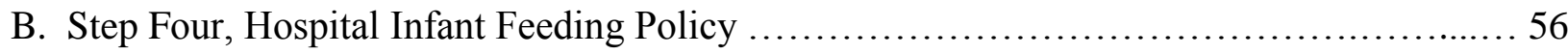

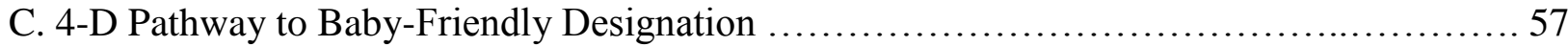

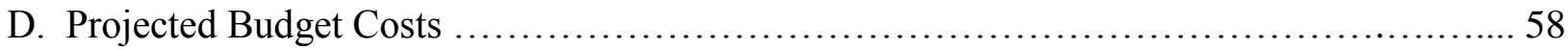

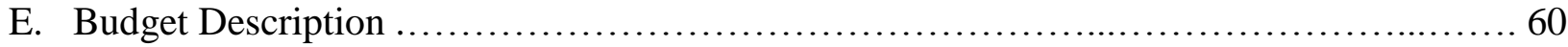

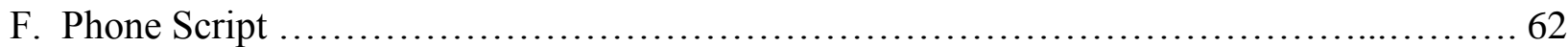

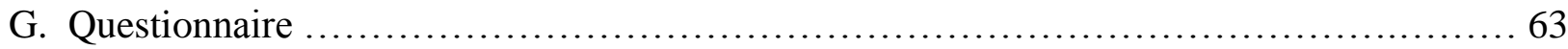

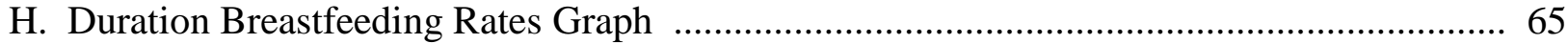

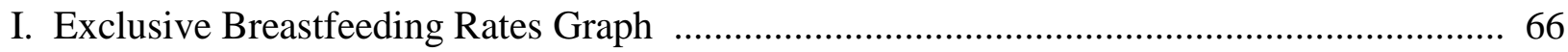

\section{List of Tables}

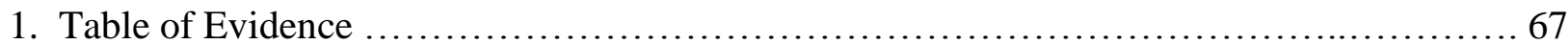

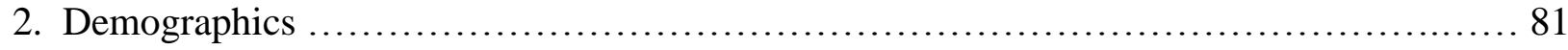

3-5. Breastfeeding Duration Rates and Chi-Square for 6 weeks, 3 and 6 months ............. 83

6-8. Exclusive Breastfeeding Rates and Chi-Square for 6 weeks, 3 and 6 months ............ 86

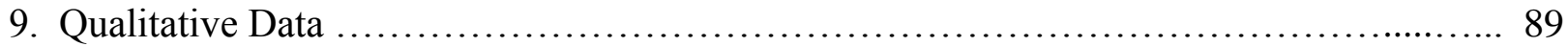




\section{Chapter I. Introduction}

Breastfeeding is beneficial to the health of both mother and infant and fosters optimal growth for the baby in the first two years of life. Evidence based guidelines followed by the Baby Friendly Hospital Initiative (BFHI) includes Ten Steps (Baby Friendly, USA, 2015). Step Four recommends placing the newborn skin-to-skin on the mother's chest to foster the initiation of breastfeeding within the first hour after birth. The question guiding this capstone project is: How does early skin-to-skin contact (SSC), in the low risk postpartum mother who plans to breastfeed, affect exclusive breastfeeding (EBF) and duration of breastfeeding rates at 6 weeks, 3 months and 6 months? The qualitative component asks: does SSC at birth affect mothers lived experience with breastfeeding? The method chosen for data collection is a retrospective cohort mixed methods design.

\section{Background}

A change currently happening in the health care system in the United States (US) is the interest in decreasing chronic illness through preventative health care. Breastfeeding lends a critical impetus to this change in society (Baby Friendly, USA, 2015). It is a free and natural process that is species specific and nourishes human infants with the ideal food for their growth and development. In the past, it was called "the white blood". In modern times, research has found that breastfeeding continually produces living cells that protect the baby immunologically; making it a medicine as well as a food (Riordan \& Auerback, 1993). Improving long term health and decreasing the rates of chronic illness is particularly important for a state such as West Virginia (WV), where obesity and chronic illness rates are among the highest in the nation (Witters, 2012).

The Agency for Healthcare Research and Quality (AHRQ) in 2007 published a summary of numerous meta-analyses and systematic reviews on breastfeeding and maternal and infant 
health outcomes in developed countries that conclusively establish the benefits of breastfeeding (Chung et al, 2007). The benefits of breastfeeding for the infant include protection against gastroenteritis, severe lower respiratory tract infections, otitis media, and necrotizing enterocolitis. The AHRQ report also found that breastfeeding is associated with decreased rates of childhood obesity, type 2 diabetes, sudden infant death syndrome, and leukemia. The benefits of breastfeeding to the mother include a reduced risk for breast and ovarian cancers and type 2 diabetes (Chung et al., 2007).

The early influences that most impact successful initiation of breastfeeding include: the birth setting, the personal health and wellbeing of the mother and infant, the mother's education and motivation level, her previous experience, SSC, and fulltime breastfeeding without supplementation (Porter, 2004). Currently the most common setting for giving birth in the US is in hospitals (Perry, Hockenberry, Lowdermilk, \& Wilson, 2010). In some facilities now and in the recent past for most of babies, it was and is acceptable for the nursing staff not to place the baby in SSC at the birth. Instead, right after the birth, the baby is dried and placed underneath a warmer, examined briefly for a physical assessment, wrapped in a small blanket, and then after completing routine procedures (such as a vitamin $\mathrm{K}$ injection and erythromycin ointment to the eyes) handed to the mother for first contact. In contrast, in 2009, BFHI global health standards were revised to include placing all newborns skin-to-skin on the mother within minutes after birth and allowing this to continue through the first hour of life, or until after the first bout of breastfeeding, barring medical complications (Crenshaw et al., 2012). Skin-to-skin contact is defined as occurring when the provider places the naked baby in a prone position against the mother's skin, on her upper torso or abdomen, immediately after birth (Appendix B). 
There are numerous benefits of SSC that the infant can experience: an analgesic effect during procedures (Okan, 2010), decreased hypothermia (Srivastava, 2014), and improved bonding and attachment behaviors (Moore, Anderson, Bergman \& Dowswell, 2012). LudingtonHoe (2015) reviewed the literature and summarized the physiologic effects of SSC as stability in: temperature, respiration, heart rate, and oxygen saturation. Term infants display a set of speciesspecific behaviors when placed SSC at birth. They find the mother's nipple through the sense of smell and have a heightened response to odors in the first few hours of life (Porter, 2004). If the baby has uninterrupted SSC immediately after birth he will self-attach to the mother's nipple which correlates with higher EBF rates (Moore, Anderson, Bergman \& Dowswell, 2012). In addition, the mother will experience less postpartum depression (Bigelow, 2012).

The population of the state of WV is 1.85 million people. Between 1999 and 2009, there was an average rate of 46.1 births per 1,000 Caucasian and 56.6 births per 1,000 African American female teens (WV Free Organization [WVFO], 2013). There are many factors that influence the breastfeeding rates of mothers in WV. Racial and economic disparities persist with breastfeeding rates lower among infants of color and among families of low socioeconomic status (Galson, 2009). Decreasing health care disparities is currently an important maternal child heath objective of Healthy People 2020 (Center for Disease Control and Prevention [CDC], 2013).

Poverty, poor housing, and low educational attainment is high in WV and research shows that women living with these demographics are less likely to breastfeed (Galson, 2009). WV has one of the highest poverty rates in the nation. The rate of children living in poverty is $25 \%$. The overall poverty rate for WV versus that of the U.S. is $18.6 \%$ versus $15.5 \%$ (County Health Rankings [CHR], 2014). If the parent is a teen (12\% of parents in WV) it is less likely that the 
mother will finish high school; which in turn effects lower employment opportunities and decreases household income in the future (CHR, 2014).

Another risk factor that negatively impacts breastfeeding rates in WV is the lack of health insurance. Women with low income have a tendency to delay care and receive inadequate prenatal care; the rate of uninsured in WV is $18 \%$ (CHR, 2014). Inadequate social support and encouragement from family and friends is also a risk factor that can undermines a mother's success in breastfeeding. The rate of mothers with inadequate social support in WV is $19 \%$ (CHR, 2014). Breastfeeding rates remain low in WV. The US Breastfeeding Report Card in 2016 reports the rate for mothers' who initiate breastfeeding in the US was $81.1 \%$, for WV it was 64.6\%; at six months the duration rate for the US was $51.8 \%$, for WV it was $35.8 \%$. The EBF rate for the US at three months was $44.4 \%$, for WV it was $32.6 \%$; at six months the EBF rate for the US was $22.3 \%$, for WV it was $14.1 \%$ (CDC, 2016).

\section{Problem Statements}

What are the effects of SSC on duration and exclusivity of breastfeeding at 6 weeks, 3 months and 6 months after the delivery of a full term healthy baby? What is the lived experience of lactating mothers who have had SSC? Increasing breastfeeding rates through the implementation of evidence based guidelines such as the Ten Steps is essential for developing a culture of breastfeeding and prevention. Little is known about the effects of early SSC (Step Four of the BFHI) on increasing breastfeeding duration and exclusivity rates at 6 weeks, 3 and 6 months of life. Little qualitative data is available related to the experience of SSC and the relationship between mother and baby. What is special and unique about the perceptions, attitudes and behavior among lactating mothers of healthy newborns who experienced SSC? 


\section{Purpose of the Project}

The purpose of the project is to examine the effects of early SSC (Step Four of the BFHI) on increasing breastfeeding duration and exclusivity rates at six weeks, three months and six months of life. A small 70 bed medical surgical hospital in rural WV consented to participate in this project. It is one of the first hospitals in WV to seek the Baby Friendly designation. The mother-baby unit at the hospital performs an average of 25 deliveries a month. In 2013 , the CDC strategies for preventing chronic diseases and obesity, and for supporting lactating mothers and babies, emphasized that health care facilities need to begin leading the society in implementing evidence based recommendations that support breastfeeding. It specifically recommends the use of the Ten Steps of the BFHI (Appendix A) to increase duration and exclusivity rates (CDC, 2013). The purpose of the qualitative component is to describe the mother's lived experiences and to explore the perceptions and attitudes among breastfeeding mothers of healthy newborns who experienced SSC. What does successful breastfeeding following SSC at birth do for the relationship of the baby and the mother? Knowing about mothers' lived experiences is essential for a provider who is concerned with designing programs that help a population focus on prevention and wellness.

\section{Significance of the Project}

In the 1980's and 90's rapidly decreasing breastfeeding rates internationally led to the creation of the Ten Steps to successful breastfeeding (WHO/UNICEF, 1998). Leaders in these organizations were concerned about the serious decline in breastfeeding rates worldwide as formula companies expanded into developing markets. Decreasing breastfeeding rates internationally resulted in the development of the Baby Friendly Hospital Initiative, BFHI (WHO, 1998). 
Baby Friendly, USA is a subsidiary of the United States Breastfeeding Committee (USBC). In the early 80's, the Innocenti Declaration was created by world leaders to protect and support breastfeeding worldwide. In 1997, the US was the last westernized nation to join the world breastfeeding community by creating the USBC. It now operates as an independent government agency. The USBC website keeps the public informed about major infant feeding issues that impact public policy. This is where the Ten Steps guidelines are available. The website includes, a weekly e-news publication, a list of the most current publications created at the national level, a tool kit created by the Joint Commission to implement the Perinatal Care Core Measures on EBF, a document covering the Core Competencies in breastfeeding for all health professionals, a list of national position statements related to the standards of breastfeeding, and a News Room (USBC, 2016). The Ten Steps, with the US Breastfeeding Committee Core Competencies, are used as a standard for initiating breastfeeding in the first six months of life for the healthy mother and infant dyad (CDC, 2016).

The Ten Steps are used to recognize and encourage birthing centers and hospitals to offer an optimal level of care for lactation. In 2013, $7.2 \%$ of the facilities in the US were designated Baby Friendly (CDC, 2013). The 2016 CDC report card indicates that the number of Baby Friendly designated hospitals have increased to $18.3 \%$ (CDC, 2016). Currently no facilities are yet designated as Baby Friendly in WV. The Core Competencies were developed to provide professionals in all disciplines, and educators, with a framework and guidelines that help to incorporate evidence-based breastfeeding knowledge into attitudes and skills for clinical practice. They recommend that all health care professionals involved with breastfeeding mothers use the competencies to integrate comprehensive and effective breastfeeding services for families (USBC, 2016). 
In recent years, a number of hospitals in WV have begun to implement Step Four, skinto-skin contact, into policy and practice (Appendix B) (WV Perinatal Partnership, 2015). The greater the number of the Ten Steps that a facility adopts the greater will be the improvement in breastfeeding outcomes (Cattaneo \& Buzzetti, 2001) (Ten Steps Appendix A). These steps for best practice include such policies as: not sending formula home with mothers at discharge, which can lead to early cessation of breastfeeding, not initially introducing babies to artificial teats or bottle nipples, which can result in nipple confusion early in breastfeeding, and twentyfour hours of rooming-in, which encourages sustained SSC (CDC, 2016). The steps recognize that the early postpartum period is an important time for establishing and supporting breastfeeding. These indicators have been added to the US Breastfeeding Report Card and are being measured nationally and state-to-state by the CDC (2016). In the fall of 2015 four hospitals in the state of WV made a commitment to work toward Baby Friendly designation (Baby Friendly, USA, 2015).

The health and economic benefits of breastfeeding are found in decreasing chronic illness rates and the impact on a wide variety of illnesses including: obesity, childhood asthma, leukemia, upper respiratory tract infections, diabetes type 1, otitis media, gastroenteritis and necrotizing enterocolitis (Weimer, 2001). In 2010, Bartick and Reinhold performed a systematic review that analyzed the evidence that examines decreasing chronic illness rates for infants who were breastfed within the American Association of Pediatrics (AAP) guidelines, and the cost benefits of following the guidelines. From the illnesses listed above, the authors found that following the EBF guidelines for three to six months lowered incidence rates significantly and brought a major benefit to cost savings. The study was also the first to analyze as many as 10 diseases (Bartick \& Reinhold, 2010). 
The economic impact of increasing exclusive and long-term breastfeeding rates is well documented and has been shown to be cost effective. Breastfed as compared to formula fed infants have fewer illnesses; as a result the total number of sick infants decline as the prevalence of breastfeeding increases (USBC, 2013). One classic study revealed that in the US $\$ 3.6$ billion could be saved if the goal for EBF for the first six months of the infant's life was achieved (Weimer, 2001). A follow up study found that 911 infant deaths per year and \$13 billion annually could be saved if $85 \%$ of US mother were to follow the recommendations for EBF (Bartick \& Reinhold, 2010). In WV, the estimated portion of savings for new mothers who follow EBF for the first six months is approximately $\$ 65$ million annually, and the mortality rate decreased by 4-5 babies in their first year of life (US Department of Agriculture [USDA], 2013).

It is economically compelling for WV to adopt the national breastfeeding goals. The estimated savings for the Women, Infants and Children (WIC) Program that provides low income families with nutrition, education, and a supplemental food packages is significant. In 2013, the U.S. spent $\$ 6.4$ billion on two million, a little over half, of the infants in the nation. WIC formula purchases accounted for about $60 \%$, of the formula sold in the US (Oliviera, Frazao \& Smallwood, 2015). In WV in 2012, of the 11,536 babies enrolled in WIC (slightly over $50 \%$ of the babies born in WV) 9,901 , or $85 \%$, were registered as formula fed fulltime. Based on a conservative estimate of $\$ 570$ average for six months of formula purchased per infant, this costs WV approximately $\$ 5,638,620$ by not meeting the EBF guideline for six months of breastfeeding (Breastfeeding Center of Ann Arbor, 2014). In the final analysis, if WV met the national breastfeeding goal of $25.5 \%$ EBF for six months it could save the WIC program approximately $\$ 1,437,848$ in formula costs. 
Breastfeeding rates in WV are currently at levels below the national recommendations and burden the state with excess spending of millions of dollars, which could be better spent on preventing chronic illness. A breastfeeding promotion culture is possible. It requires a change that is supported by facilities using evidence based guidelines, a community-wide network of support, a commitment to achieving the national breastfeeding goals and decreasing chronic illness. Nurses, nurse-practitioners, and midwifes have an ethical responsibility to support this in practice. It was the intent of this capstone to compare the duration and exclusive breastfeeding rates of mothers delivering full term, healthy babies in one West Virginia hospital before and after the implementation of SSC and describe the lived experience of mothers who had experienced SCC. 


\section{Chapter II. Literature Review}

The purpose of this review of the literature is to evaluate the research about how early SSC affects initiation, duration and exclusivity of breastfeeding; and the impact of SSC on the lived experience of the mother in the first months of the infant's life. The BFHI Ten Steps represent maternal-child health care best practices (Carfoot, Williamson, \& Dickson, 2005).

\section{Search Strategy}

The electronic databases searched included: Cochran Library for Systematic Reviews, National Guidelines Clearinghouse, West Virginia University full-text databases, PubMed and CINAHL. A hand search performed in two professional journals, the Journal of Midwifery and Woman's Health and Birth: Issues in Perinatal Care was conducted. The search terms included: exclusive breastfeeding, fulltime breastfeeding, skin-to-skin contact, and kangaroo mother care. These terms were paired together to narrow the results: early SSC and EBF, early SSC and breastfeeding duration, and early SSC and fulltime breastfeeding. Inclusion criteria for the studies were: clinical trials and full text, English language, human studies only, and healthy mothers and infants at term. Eventually clinical trials were included to yield more results.

The search used the keywords "exclusive breastfeeding" which yielded 1,147 hits. When early SSC was added it yielded 110 hits. Adding other key terms reduced the yield to 24 hits. Initial searching included the past 10 years; this was changed to the last five years to narrow the results. Systematically entering the terms within the other databases, eliminating duplicate articles, and hand searching, yielded nine relevant articles. Six additional articles were obtained when the search was broadened to include mothers lived experience and the Ten Steps and BFHI. Four of the articles added to the depth of understanding for the qualitative arm of the project. 
Broadening the search yielded a greater understanding of the Ten Step as a whole, in combination, and in relation to: the effects of SSC on premature infants, comparison of different country rates when using the Ten Steps, SSC and preventing infant hypothermia, and SSC and cesarean births. No research has been conducted in WV related to this topic. Much of the research came from the initial countries where BFHI began in the 1960's (Columbia, England, Sweden, Pakistan, India, and Poland). In the US, designation of Baby Friendly hospitals did not begin until the 1990's (Chung et al., 2007).

Overall the initial search yielded: one Cochrane Database of Systematic Reviews article (Moore, Anderson, Bergman \& Dowswell, 2012); five randomized control trials, RCTs (Charpak, Ruiz-Peláez, Figueroa de, \& Charpak, 2001; Carfoot, Williamson, \& Dickson, 2005; Mahmood, Jamal, \& Khan, 2011; Thukral et al., 2012; Moore \& Anderson, 2007), two analytic observation studies, both prospective cohort designs (Bramson et al., 2010; Mikiel-Kostyra, Mazur, \& Boltruszko, 2002), two descriptive observational studies (DiFrisco et al., 2011; Crenshaw et al., 2012); one correlational observation study (Linares et al., 2016); two qualitative systematic review studies (part 1 and 2) (Anderzén-Carlsson, Lamy, \& Eriksson, 2014; Anderzén-Carlsson, Lamy, Tingvall, \& Eriksson, 2014 ); and two descriptive qualitative studies (Palmér, Carlsson, Mollberg, \& Nyström, 2010; Finnigan, 2009). Additional research based articles include: one clinical practice guideline (NGC, 2008), a clinical protocol from the Association for Breastfeeding Medicine, Peripartum Breastfeeding Management for the Healthy Mother and Infant at Term (Holmes, Yerdon, \& Maya, 2013); and the CDC Guide to Strategies to Support Breastfeeding Mothers and Babies (CDC, 2013). 


\section{Quantitative Research}

A critical analysis of the studies was conducted by utilizing the new Scottish

Intercollegiate Guidelines Network (SIGN) forms for critical appraisal (SIGN, 2013). A second researcher corroborated in the systematic review of the literature (Table I.).

The review begins with the meta-analysis by Moore et al. (2012). This CDSR examined randomized control trials that compared SSC with usual hospital care. Thirty-four RCTs included involved 2,177 mother-infant dyads. The primary outcomes from 13 trials with 702 participants included a significantly positive effect of early SSC on breastfeeding at one to four months: $\mathrm{RR}=1.27,95 \% \mathrm{CI}-1.06$ to 1.53 . Seven trials with 324 participants indicated that SSC increased breastfeeding duration but without significance (mean difference of 42.55 days, $95 \%$ CI -1.69 to $86.79, \mathrm{P}=0.06)$. Strengths of the review included: RCT design, large sample numbers with combined statistics, and clear and specific recommendations. The limitations included: mixed methods with heterogeneity, and variations in implementation and outcomes related to the intervention. The authors concluded that SSC appears to benefit breastfeeding outcomes, and there are no short or long-term negative effects.

Five RCTs were examined (Charpak et al., 2001; Carfoot et al., 2005; Mahmood et al., 2011, Thukral et al., 2012; Moore et al., 2007); sample sizes ranged from 20 to 746 participants. Each was conducted in a different country. Measuring duration of breastfeeding varied among the studies. Two studies measured the effect of SSC on EBF at one month (Mahmood et al., 2011; Moore et al., 2007), one measured the effect at six weeks (Thukral et al., 2012), while one RCT measured the effect at four months (Carfoot et al., 2005). The remaining RCT examined the effect of SSC on EBF and partial breastfeeding at 1,3,6,9, and 12 months (Charpak et al., 2001). All but one of the studies (Charpak et al., 2001) used the Infant Breastfeeding 
Assessment Tool (IBFAT) or a related version of this valid and reliable tool. Charpak et al. (2001) utilized hospital and clinic records that contained the measurement data from the patient visits.

The results of four of the RCTs showed a significant difference in initiation of breastfeeding success between the mother-infant pairs who received SSC as an intervention and the control group who did not (Charpak et al., 2001; Mahmood et al., 2011; Thukral et al., 2012; Moore et al., 2007). Two RCTs showed a significant difference after SSC, in success at one month (Charpak et al., 2001; Mahmood, 2011) and one at six weeks (Thukral et al., 2012). One study demonstrated significant difference at 1 and 3 months but not at 6,9 , or 12 months (Charpak et al., 2001). One study demonstrated no significant difference in breastfeeding at initiation or at 4 months when the mother-infant pairs were exposed to early SSC (Carfoot et al., 2005).

A common strength found in the five RCTs was randomization of the participants, which demonstrated strength in internal validity. Charpak et al. (2001) utilized stratified block lists that were prepared from a list of random numbers, two of the studies used a computer generated randomization list (Carfoot et al., 2005; Mahmood et al., 2011), Thukral et al. (2012) utilized randomization with allocation concealment, and Moore et al. (2007) used randomization with minimization. The standard IBFAT (Infant Breastfeeding Assessment Tool) tool was used in four of the five studies and added to internal reliability and consistency. Two of the studies amended the tool (Carfoot et al., 2005; Thukral et al., 2012) but both reported face validity in the revision. Measurement was appropriate among all of the RCTs for analysis by odds ratio, relative risk or confidence intervals. 
Each observational study compared two groups: one received the intervention of SSC, and the other received conventional care after the birth. Five observational studies were included (Bramson et al., 2010; Mikiel-Kostyra et al., 2002; DiFrisco et al., 2011; Crenshaw et al., 2012; Linares et al., 2016). The studies evaluated the relationship of early SSC with success in suckling competency or EBF rates at initiation; and the range of duration in breastfeeding rates examined spanned from a few days to six months. Location of studies had a large international representation. Four were conducted in the USA and one each in Columbia, England, Pakistan, India and Poland.

Two of the observational studies used prospective cohort designs (Bramson et al., 2010; Mikiel-Kostyra et al., 2002). The largest sample sizes in this review were in these two studies: the study by Bramson et al. (2010) was conducted in the USA and included 21,842 participants; while the study by Mikiel-Kostyra et al. (2002) was conducted in Poland and included 11,973 participants. Both used questionnaires for the data collection. Results demonstrated a doseresponse relationship (Bramson et al., 2010) between early SSC and EBF increasing in significance each increment of time for SSC. Mikiel-Kostyra et al. (2002) demonstrated that the implementation of SSC significantly increased duration of breastfeeding over time and that the longer an infant experienced the SSC the longer the breastfeeding duration.

Two of the studies used descriptive observational designs (DiFrisco et al., 2011; Crenshaw et al., 2012). Sample size ranged from 113 to 300. In both studies, the researchers collecting the initial data had training. In Crenshaw et al. (2012), a monthly survey of rates was done as follow up. Results in one study demonstrated a significant difference in exclusive breastfeeding rates at discharge, two and four weeks among mother-infant pairs who received SSC (Defrisco et al., 2011). Crenshaw et al. (2012) demonstrated an overall increase in 
breastfeeding duration over five months among the SSC pairs, but failed to find a significant difference in the EBF rates across the six months of the study.

A correlational observational study (Linares et al., 2016) evaluated the influence of early SSC on initiation and sustained EBF at one month postpartum. The longitudinal study used a convenience sample of 100 breastfeeding Hispanic mothers. Through the use of differential statistics the study showed findings in the early SSC group associated with a sevenfold increase in the odds of EBF at discharge $(\mathrm{p}=.005)$. However, it was not predictive of EBF at 1 month post-discharge $(\mathrm{p}=.7)$. The results also indicated that the younger the maternal age, and the greater the prenatal infant feeding intention, the greater the association with an increased likelihood of EBF across both time points (Linares et al., 2016). The strengths of the study included: it was a well conducted study using bivariate analysis; and it was one of the first studies to examine the effect of SSC and EBF among Hispanics. Limitations included: a convenience sample, a small study, and reasons for not practicing SSC were not documented in some of the infant charts.

Strengths among the cohort studies were found in the large sample sizes (Bramson et al., 2010; Mikiel-Kostyra et al., 2002). Bramson et al. (2010) performed a unique study demonstrating a dose-response relationship between SSC and EBF and strength in its sensitivity by isolating variables that could become confounders (the mother's intention to breastfeed, medication received during labor and delivery, and cesarean delivery). The design of the study by Mikiel-Kostyra et al. (2002) showed strength in examining EBF over an extended period of time (three years).

The two descriptive studies both demonstrated findings consistent with previous research (Defrisco et al., 2011; Crenshaw et al., 2012). The sample sizes ranged from 113 to 300 
participants. Crenshaw et al. (2012) performed a unique study in that it demonstrated the importance of the nurses' role in affecting change in a hospital maternity unit, with a key role in implementing the pilot project and staff training. Although this study did not show a significant difference in EBF across the six months it did demonstrate an increase in SSC above baseline by $25 \%$ over the five months after the staff training in SSC techniques.

Limitations among the studies included: mixed designs, variation in sample size, inconsistency in controlling for confounders, and potential for cultural bias limiting extended breastfeeding rates. Controlling for potential confounders in baseline characteristics varied across all the studies. Three studies controlled for pain medicines used in labor (Bramson et al., 2010; Carfoot et al., 2005; Crenshaw et al., 2012), five for mode of delivery (Bramson et al., 2010; Carfoot et al., 2005; Crenshaw et al., 2012; Defrisco et al., 2011; Moore et al., 2007), six for previous experience with breastfeeding (Carfoot et al., 2005; Crenshaw et al., 2012; Defrisco et al., 2011; Mahmood et al., 2011; Moore et al., 2007; Thukral et al., 2012), four for maternal education (Bramson et al., 2010; Mahmood et al., 2011; Mikiel-Kostyra et al., 2002; Thukral et al., 2012), and one for maternal employment (Moore et al., 2007). One study did not separate the characteristics of exclusive and partial breastfeeding (Charpak et al., 2001).

A clinical guideline located in the National Guideline Clearinghouse (2008) entitled Peripartum Breastfeeding Management for the Healthy Mother and Infant at Term was analyzed. The Appraisal of Guidelines for Research and Evaluation (Agree II) Instrument was used for the critical analysis of this guideline in this systematic review (Canadian Institute of Health Research, CIHR, 2009). Recommendations and major outcomes relevant to early SSC and peripartum breastfeeding include: successful initiation of breastfeeding in the birth setting; delaying weights, measurements, and medications before the first feeding in the delivery or 
recovery room; and ensuring that women are able to position and attach their babies to the breast by the time of discharge (NGC, 2008; The Academy of Breastfeeding Medicine Protocol Committee, 2008). Strengths of the guideline include: clear description of the objectives and the health question, systematic methods utilized in the search of the evidence, well documented references, and the body of evidence was clearly discussed with external and internal peer review performed. Limitations related to this guideline included: a description of methods used to formulate the recommendations was not stated, and no procedure for updating the guideline was reported.

The Academy of Breastfeeding Medicine in Clinical Protocol \#5: the Peripartum Breastfeeding Management for the Healthy Mother and Infant at Term, revision, recommends as best guidelines for initiation of breastfeeding at the birth, that a healthy and term newborn be handed to the mother for direct SSC (Holmes, Yerdon, \& Maya, 2013). The Apgar scores can be assigned as the baby is dried and placed upon the mother's skin, where the first physical assessment is performed, allowing for optimal warmth and physiologic stability and providing an opportunity to breastfeed. The likelihood of EBF increases as extensive SSC is followed.

Delaying procedures up to six hours increases early mother-child interaction. Placing the infant close to the breast allows for latching in the first hour after birth. The protocol recommends this practice be initiated in the birthing, recovery or operating rooms. Mothers are best served when offered instructions about techniques for breastfeeding.

\section{Qualitative Research}

Anderzén-Carlsson, Lamy and Eriksson (2014) performed the first qualitative systematic review investigating parental experiences and SSC. Part I of the study contained systematic and manual searches that led to the inclusion of 29 original qualitative papers, from 9 countries, with 
a sample of 401 mothers and 94 fathers. Part II synthesized and interpreted qualitative research findings from the same studies (Anderzén-Carlsson, Lamy, Tingvall \& Eriksson, 2014). In Part I, two themes emerged which described SSC as a restoring experience and an energy-draining experience. In Part II, a theoretical model of becoming a parent under unfamiliar circumstances emerged. The lived experiences viewed SSC as a positive experience which facilitates the growth of self-esteem and assists in readiness for assuming full responsibility for the child, and as a family enriching experience. The strengths of this review include: it is the first qualitative meta-synthesis on the subject, it has added to systematic knowledge about parental experiences following SSC, and it is well conducted qualitative research drawn from four databases with 29 original qualitative papers.

Two studies that use a qualitative design to explore the mothers lived experience with SSC were analyzed. Palmer et al. (2010) examined the lived experiences of eight women within the context of early home discharge, who were interviewed at two months postpartum. The authors used a reflective lifeworld research design based on phenomenological philosophy. Essential meaning for the parents was organized in light of five concepts: fascination in the first encounter with the baby, balancing the unknown, enduring and devoting oneself to the situation, seeking and discovering the unique, and having the entire responsibility. The authors concluded that: breastfeeding is intertwined with biological and existential issues that cannot be separated into different parts, and must be viewed as a whole and living experience (Palmer et al., 2010). The strengths of the study included: it is well conducted qualitative research, the birth stories contribute rich knowledge that balance the rigors of statistical research, and it adds depth and breadth to the perspective of breastfeeding by seeing the relationship of the mother and infant in its wholeness as a lived experience. The limitations include: it is descriptive research, and the 
midwife researcher expressed that it was difficult to separate her own lived experiences from that of the mothers in the study.

Finigan et al. (2009) examined six mothers lived experiences of SSC with their baby immediately after birth, focusing on the women's personal perspectives for understanding whether or not SSC is a 'mother-friendly' approach. The mothers kept an audiotaped diary for 28 days postpartum. This was followed by an in-depth interview on day 28. All interviews were audiotaped and the diaries transcribed verbatim. The women verbalized emotive and visceral language to describe their experiences with SSC and their newborns after birth. Five themes were discovered as mothers described their babies and the SSC experience: immediate feelings of bonding, stroking and touching, gazing and coming to know the baby, viewing it as a natural and instinctive process, and not wanting to let go of the infant (Finigan et al., 2009). The strengths of the research include the mothers' descriptions of SSC as instinctive and emotional: increasing their desire for a longer period of uninterrupted SSC, helping them feel that the baby was a reward for the stress of labor, and expressing that it was a pleasurable and important birth memory. The limitations include: the small numbers and the feelings of the mothers that their partners were more like spectators. Fathers were not included in the study and the author encourages the involvement of fathers in future studies.

\section{Synthesis}

Three RCTs (Charpak et al., 2001; Mahmood et al., 2011; Thukral et al., 2012), two cohort studies (Bramson et al., 2010; Mikiel-Kostyra et al., 2002) and one descriptive study (Defrisco et al., 2011) demonstrated that SSC significantly enhances the success of breastfeeding initiation and the continuation of breastfeeding (combined and exclusive) within the first three months. One meta-analysis (Moore et al., 2012), two RCTs (Carfoot et al., 2005; Moore et al., 
2007) and one descriptive study (Crenshaw et al., 2012) do not show SSC as a significant influence on extended breastfeeding in the first four months. The studies were of mixed design and heterogeneity existed with diversity among sample populations due to differences in inclusion criteria.

Variation in intervention, implementation, design methods and outcomes are limitations that could diminish the statistical significance of the studies. The evidence regarding the benefit of SSC is inconsistent and needs additional studies that control for: pain medicine, mode of delivery, previous experience with breastfeeding, maternal education and mothers returning to work. Future research requires repeated randomized controlled trials with homogenous populations to expand the knowledge base about SSC and confidence in its relationship to breastfeeding duration and exclusivity.

The trials in this review show that early SSC appears to benefit breastfeeding outcomes. Increasing the length of exposure to early SSC shows a dose related response between the early SSC and EBF (Bramson et al., 2010). One implication for practice suggests that routine early medical assessments of the mother-infant dyad should not interfere with the initial SSC, following both vaginal and cesarean births. Promoting SSC at birth is a simple and inexpensive measure the nurse can perform to support breastfeeding success in the early period and it appears to have no negative effects (Moore et al., 2012).

\section{Implementation of Change within the System}

In selecting a theoretical framework for this proposal it was important to find one that supported the implementation of change within the health care system in WV through the creation of a breastfeeding culture, and one that complemented the independent and selfsufficiency characteristics of the Appalachian people. 
Factors that contribute to the complexities of supporting a culture of breastfeeding in WV are interwoven into the Appalachian culture and the women's ability for self-care in pregnancy and lactation. West Virginia is a rural and relatively new state, founded in 1863 . The rural nature of the state with numerous geographically isolated counties, combined with the shortage of health care providers, can make it difficult for mothers to get breastfeeding support when needed. The way of life in WV reflects a rich mixture of Native American and European ancestry and culture. Both of these cultures have a clan orientation with closely knit families and a distrust of outsiders, until trust is earned (Behringer \& Friedell, 2006). The rural mountainous terrain reinforces the natural independence within the Appalachian people who value hard work and problem solving for themselves. This quality of self-sufficiency influences their reluctance to seek care from the greater health care system (Behringer \& Friedell, 2006). The birth experience is an opportunity for the nursing and midwifery community to help the mother and family learn about and experience successful breastfeeding.

Bandura's Self-Efficacy Theory is a theoretical framework that integrates cognitive, motivational and affective perceptual processes into a unified concept of behavior. Self-efficacy is an important psychological mechanism that links psychosocial influences to physiological processes and health functioning (Bandura, 1992). A central concept of the theory is that each person's unique perceptions and judgements about his or her own capabilities largely influence what he or she is able to learn about in each life situation. People with self-efficacy have a framework which organizes their perceptions psycho-bio-socially into confidence in their own capabilities. The theory understands that the stronger the self-efficacy beliefs of a person the greater the possibility that a behavior will be initiated and sustained, and the greater the perseverance in challenging times (Schwarzer, 1992). This project is concerned with supporting 
a new mother's confidence and breastfeeding initiation through the physiologic and psychological changes of birth.

Bandura organizes learning into four principles which influence perceived self-efficacy: mastery of learning as manifested in the practice of a new role or skill; vicarious learning as manifested in role modeling; symbolic learning as manifested in support and encouragement from others; and physiologic processes that have a direct influence on behavior (Bandura,1992).

The physiologic principle is involved with the implementations of SSC at delivery and the direct physiologic effect of lactation initiation. After the separation of the placenta, if the healthy term newborn is placed into SSC, he or she will initiate self- exploration, find the breast and begin suckling. The suckling process stimulates the pituitary axis. Prolactin rises in the blood and human milk is produced, a species-specific lifesaving fluid. As newborn suckling increases the quantity of milk rises in the alveolar sacs, and the second maternal hormone oxytocin is released into the blood to stimulate the letdown effect. Oxytocin also has a powerful effect on the mother keeping her riveted on protecting her newborn infant. As lactation increases so does the level of the two maternal hormones in the blood; this leads to further maternalnewborn bonding and self-efficacy behaviors.

The symbolic learning principle is utilized through the support and promotion of Step Four by the nursing staff. When the procedures are delayed until after the newborn has had its special time with the mother, the nursing staff is offering encouragement toward establishing an important and essential relationship in society, the bond of a new mother and baby. The staff will help both the mother and newborn transition and develop the self-efficacy needed for a new role. 
The vicarious learning principle applies as the nurse educates the mother and models the skills needed for her and the infant to sustain breastfeeding. This learning principle can be applied to include both mother and father. As the mother keeps the baby near the breast and includes the father in the feeling of closeness in this relationship, he too is experiencing vicarious learning and is gaining confidence in self-efficacy behaviors.

The final learning principle of Bandura's self-efficacy theory is the learning that comes with practice and mastery (Bandura, 1992). Through it the lactating mother experiences repeated success in the psychologic and physiologic processes of breastfeeding. The framework can also be applied to help the family support each member in the self-efficacy behaviors needed for the goal of EBF during the first six months of life. It also applies to empowering mothers (through the symbolic learning principle) to share their personal stories and experiences with SSC and breastfeeding. The framework can also be a guide to the nurse midwife who helps the new mother gain mastery in breastfeeding, so that the nurse can support the self-efficacy needs of the mother as she arises to meet the physiological challenges of supply and demand. 


\section{Chapter III. Methodology \\ Project}

\section{Description and Design}

The capstone project was conducted using a retrospective cohort, mixed methods design to evaluate the effect of SSC on duration and exclusivity of breastfeeding in healthy postpartum mothers. It focused on the effect of the application of SSC, using Step Four of the Ten Steps of the Baby Friendly guidelines (Appendix A). After implementing SSC into policy, April 2014, the mother/baby nurses and stakeholders learned about the process of initiating SSC in the first 90 minutes of life (Appendix B). The inclusion criteria for the intervention cohort included mothers who were English speaking, over 18 years old, and chose to breastfeed for the first time. Mothers were included who had experienced uncomplicated vaginal deliveries with healthy term infants who had an eight or higher Apgar score by five minutes, and received SSC following the birth of their baby. The comparison cohort included mothers meeting the same criteria who received the traditional non-SSC method of care.

The participants who delivered between April 1, 2014-September 30, 2016 were included in the intervention cohort. The participants who delivered between January 1, 2012-March 31, 2014 were included in the comparison cohort, before SSC was implemented into policy. The names and phone numbers were provided to the investigator through the delivery logs on the mother-baby unit and the computerized medical records. The list of patient names and numbers were kept separate from the questionnaire, with an identifier on each, to ensure confidentiality and anonymity. Data for breastfeeding rates was obtained through a survey questionnaire completed in a phone interview. The data was analyzed for rates at 6 weeks, 3 months and 6 months. The instruments, the script and questionnaire, were approved by the WVU Institutional 
Review Board (Appendices F \& G). The project leader followed the script exactly as approved. Each woman was offered disclosure and an invitation to participate. The questionnaire (Appendix G) included an introduction, disclosure, and questions addressing the quantitative leg that were asked of the comparison group, and the quantitative and qualitative leg of the cohort group. All consenting participants chose to answer the entire questionnaire during the phone call. An unanswered first phone call was followed-up with several more phone calls, at different hours of the day, before dropping the potential subject from the project.

This researcher is an instrument of the qualitative leg. She personally has experience with exclusive and long-term breastfeeding of three children. The researcher was careful to focus on the fact that each of the participants had their own unique experience which was faithfully recorded in their own words.

\section{Needs Assessment and Feasibility Analysis}

On a national level Healthy People 2020 and Baby Friendly, USA made goals to increase breastfeeding rates for the nation at initiation, three months, six months and one year. At present the $\mathrm{CDC}$ is collecting data on initiation rates state by state

The project is the first community attempt to collect data on this topic beyond hospital discharge for a population in WV. In the fall 2016, the hospital made an application to the CDC Empower Initiative, was awarded a small grant and signed a contract with the intent to work through the Ten Steps. The new policies were written and a hospital wide breastfeeding committee began to meet regularly. The present researcher served as a team member, helping with updating policies and quarterly quality reviews. When the hospital made the commitment to carry out the designation goals of BFHI, the key stakeholders agreed to implement all Ten Steps within a two year period. The process has a 4-D pathway to Baby-Friendly designation: 
D1-discovery, D2- development, D-3 dissemination, and D-4 designation (Appendix C). The hospital is currently in D-3, and it is focused on implementing the policies related to implementing all of the Ten Steps. The effect of Step Four has not been evaluated, beyond hospital discharge, making the value of this project apparent. The project was clearly feasible as the hospital was committed to attaining a Baby-Friendly designation.

\section{Resources and Budget}

The researcher of the project recognized that implementation of SSC does not add an additional financial burden on the hospital. In examining the resources, it is apparent that the hospital had already budgeted to manage the mother-baby unit (MBU). Nurses are salaried, patients are admitted and discharged, and the rooms are used for the same amount of time. No additional expense or investment was incurred through the collection of the retrospective data. The primary resource was the mother who desired to breastfeed and the newborn baby. SSC aims to foster the natural production of breast milk, which is free and readily available. Other resources included the staff nurses, and the prenatal care given by the hospital prior to the birth. A detailed budget description (Appendices D and E) identified that small grant funds were used to cover the costs of this project and the man-hours were donated by the investigator. No financial plan beyond the commitment and the nominal initial fee to Baby Friendly, USA has been incurred by the hospital. This Capstone Project goes beyond the programmed data collected for BFHI D2 to collect outcomes for breastfeeding duration and exclusivity at 6 weeks, 3 months and 6 month rates. It also has a qualitative leg exploring mother's lived experience with breastfeeding following SSC. 


\section{Project Objectives}

1. To compare the breastfeeding duration rates at 6 weeks, 3 months and 6 months for the mother-infant dyads who received SSC at birth (4/1/2014 to 9/30/2016) to the mother-infant dyads who did not receive SSC at birth (1/1/2012 -3/31/2014).

2. To compare the EBF rates at 6 weeks, 3 months and 6 months for the mother-infant dyads who received SSC at birth (4/1/2014 to 9/30/2016) to the mother-infant dyads who did not receive SSC at birth (1/1/2012 -3/31/2014).

3. To explore the lived experience of mothers who received SSC and breastfed their infants; and record the responses in their own words, as they describe their early breastfeeding and bonding experience after receiving SSC. 


\section{Chapter IV. Results}

The project explored the impact of SSC, Step Four of the Ten Steps, when implemented into hospital policy and how it affected breastfeeding rates and mothers' lived experiences with breastfeeding in the early months of an infant's life. Designation of Baby Friendly status is now included in the national report card from the CDC. This is the first project, from a facility seeking Baby Friendly status in WV, to examine breastfeeding rates beyond discharge.

\section{Sample and participants}

One hundred and fifty mothers initially were included in each cohort for a total of 300 possible participants. A total of one hundred fifteen (115) questionnaires were completed. A total of one hundred eighty-five (185) questionnaires were not completed due to: wrong numbers, current phone number unknown, unanswered phone calls after multiple attempts, mothers declining to participate, or reporting the decision to formula feed the first day home.

Within the intervention cohort, 34 participants completed questionnaires and met the inclusion criteria for the quantitative and qualitative legs of the project. Only participants who had experienced SSC and met the inclusion criteria were included in the qualitative leg of the project. Within the comparison cohort, 21 met the inclusion criteria for the quantitative leg of the project.

\section{Demographics}

There were no significant differences in the means of the variables between the cohorts (Table 2). All participants were inexperienced, healthy, breastfeeding mothers. They successfully delivered a healthy term infant vaginally, the infant had an Apgar score $>8$ at 5 minutes, the mother was in her mid-twenties at the time of the delivery and continued breastfeeding after returning home. The majority of the participants were: Caucasian, 
breastfeeding their first child, supported by family or friends during the breastfeeding experience, and were healthy prior to the pregnancy. Close to half of the participants in each group took a maternity leave. Those in the non-SSC cohort had a mean length of maternityleave of 3 weeks, and those in the SSC had a mean length of maternity leave of five weeks. Close to half of the participants in each group (44\% vs. $48 \%$ ) reported problems with the breastfeeding experience. The non-SSC cohort had a higher rate of health problems with the pregnancy than the SSC (33\% vs. 18\%). The SSC cohort had a lower rate of desiring that their breastfeeding experience had been longer, than the non-SSC (30\% vs. 33\%). The SSC cohort lower rate of $30 \%$ is only accurate to an " $n$ " of 23 because eleven mothers in the SSC were still breastfeeding at the time of the interview.

\section{Quantitative}

The first objective of the project compared the duration of breastfeeding rates at 6 weeks, 3 months and 6 months. This was evaluated by using the Chi square for independence statistic (Tables 3-5). In the cohorts, $82.4 \%$ (SSC) vs. $61.9 \%$ (non-SSC) were breastfeeding at 6 weeks (p. $=0.170)$. At 3 months, $73.5 \%($ SSC) vs. 52.4\% (non-SCC) were breastfeeding $($ p. $=0.190)$. In the cohorts, $44.1 \%$ (SSC) vs. $42.9 \%$ (non SSC) were still breastfeeding at 6 months (p. = 0.170). Phi coefficient for effect was $0.228,0.216$, and 0.012 at 6 weeks, 3 months, and 6 months indicating that SSC demonstrated a small effect on the breastfeeding rates. Although the breastfeeding rates for the intervention cohort at all time periods were higher, there were no significant differences between the groups.

The second objective of the project compared exclusive breastfeeding rates at 6 weeks, 3 months and 6 months. This was evaluated by using the Chi square for independence statistic (Tables 6-8). In the cohorts, the exclusive breastfeeding rates for the intervention cohort at 
6 weeks were $73.5 \%(\mathrm{SSC})$ vs. $57.1 \%($ non-SSC) $(\mathrm{p} .=0.336)$. At 3 months, $64.7 \%(\mathrm{SCC})$

vs. $33.3 \%$ (non-SCC) were breastfeeding $(\mathrm{p}=0.533)$. In the cohorts, $20.6 \%$ (SSC) vs. $23.8 \%$ (non-SCC) were still exclusively breastfeeding at 6 months $(\mathrm{p} .=1.00)$. Phi for effect demonstrated 0.170, 0.122, and 0.038 at 6 weeks, 3 months, and 6 months indicating that the SSC demonstrated a small effect. The exclusive breastfeeding rates for the intervention cohort at 6 weeks and 3 month time periods were higher, and at 6 months were slightly lower; there were no significant differences between any of the groups.

\section{Qualitative}

The third objective described the lived experience of those mothers who had been involved with SSC. Questionnaires were analyzed for themes by two independent reviewers. The qualitative data (Table 9) about the effects of SSC came from the survey question; do you have anything you would like to share about your birth, the skin-to-skin experience, and the first memories of seeing and touching your child? Exploration of the responses includes a description of how SSC affected the mother, and how SSC affected her breastfeeding experience. The word bonding came up spontaneously so frequently that it was added as an independent descriptor.

The themes that emerged were: it helped with bonding to the baby, it helped with breastfeeding the baby, and SSC had an ongoing effect once we were home. One participant reported, SSC absolutely helped to breastfeed longer and be successful. Both my husband and I participated. It was indescribable. Another theme was the mothers' disappointment at not being able to breastfeed longer. Such responses included: I did not feel there was enough breastfeeding support at the hospital; and I couldn't work and pump enough so I had to stop breastfeeding. Reasons included mastitis, pain, the milk drying up, and returning to school or work. The descriptor with the highest frequency related to how the SSC experience affected 
only breastfeeding was, it helped me get breastfeeding started. The descriptor with the highest frequency related how the SSC experience affected bonding and breastfeeding; it helped me to bond to the baby, and breastfeed the baby (Table 9). Some participants shared more in-depth explanations:

I had skin-to-skin with the second baby. It was a different experience. I felt that something was missing with the first that I could not explain. With my son, the second one, I thought it was a dream come true. I am so grateful.

I wouldn't have missed out on it and would do it all over again. It immediately helped me to breastfeed and I didn't have any complications like my friend did.

The SSC gives you more of a bond and I continued with skin-to-skin at home to calm her down. My baby loved to go to sleep on my chest. At times, it was the only way that I could get her to sleep.

\section{Key Facilitators and Barriers}

There were a number of facilitators for the project. The hospital leaders were aware that the literature clearly supported the benefits of breastfeeding and they were committed to the evidence based guidelines needed to achieve Baby Friendly designation. The interest in preventative healthcare and decreasing health care costs nationwide is renewing an interest in creating a breastfeeding culture at the state and local level. The BFHI has been well established worldwide since the 1980 's. The US now has a national breastfeeding committee that promotes setting breastfeeding goals at the state and local level. Breastfeeding became legalized in WV in April 2014 (National Conference of State Legislatures, 2016).

There were also some impediments to the successful implementation of the project. When SSC is implemented it affects an increase in early breastfeeding rates and creates an unmet 
need for breastfeeding support beyond discharge. Several women identified that had they had support after discharge, they might have been able to continue breastfeeding longer. Currently the health care system, as a whole, is not set-up to support breastfeeding outside of the hospital. Women need a plan for follow-up after discharge; two thirds of the women in this project were unreachable by phone, making them invisible to the project. WIC contains the main reservoir of IBCLC breastfeeding certified experts available to women in the community. Fifty percent of the population does not receive WIC and does not have access to these experts. Initial support, at the hospital, is all that half the mothers are offered. Currently there are no statewide breastfeeding goals in WV.

\section{Further Findings from the Data}

The qualitative leg includes the unintended consequence of: one, creating an unmet need for more breastfeeding support in the community as the breastfeeding rates grow; two, the data shows that $50 \%$ of the women in the SSC cohort, and $30 \%$ in the baseline group, expressed a desired to be able to breastfeed longer; three, in the data there is little difference between duration and exclusive breast-feeding rates between the intervention and comparison group; four, half of the women didn't take maternity leave and those who took it returned to work at around six weeks.

The qualitative leg also identified some interesting findings. Participants spontaneously expressed gratitude about how much they appreciated the investigator caring and listening to their birth and breastfeeding experiences. One mother reported that her initial SSC experience helped her to bond later when her baby had to go into the neonatal intensive care nursery for an unexpected problem. Another mother reported that she felt the SSC experience at birth prevented her from having postpartum depression with her second baby. Another mother 
reported the need to work through feelings of guilt because she felt closer to her second baby, who had received the SSC at the birth. Three participants believed that they could not provide enough milk for their babies. This concern was shared with a Pediatrician, or a nurse, and the belief was reinforced. Two participants reported that their partners felt cheated out of the feeding experience; they felt that when their partners participated in SSC with the baby, this made them feel that they also had a special bond with the baby. 


\section{Chapter V. Discussion and Recommendations}

Bandura's theory of Self-efficacy organizes learning into four principles which influence perceived self-efficacy by the mother- infant dyad. First, the physiologic principle of learning had a direct effect on the process of breastfeeding and bonding when SSC was implemented in the first moments of life. It was seen that the intervention positively supported the new skills needed for breastfeeding. As a unit, the mother and infant learned through SSC how to breastfeed for the first time. The project also found that EBF rates of breastfeeding were higher at 6 weeks and 3 months, and duration rates were higher when breastfeeding skills are initiated after SSC.

Vicarious learning manifested in the role modeling seen as the nurses applied the new SSC policy of placing the newborn upon the healthy mother's abdomen within moments after birth. This learning principle was also observed as the mother kept the baby near her breast and included the father in the feeling of closeness in the relationship. In the qualitative component some mothers reported that some of the fathers reported feeling involved in, and not left out of, the special feeding and bonding experience the mothers experienced with their newborns.

Symbolic learning was manifested in support and encouragement from others that aided the project through the promotion of Step Four. This was achieved when the nursing staff: delayed procedures until after the newborn had its special time with the mother, offered encouragement for establishing breastfeeding, and promoted the new bond of the mother and baby that was beginning to form. This process helped the staff to strengthen the self-efficacy needs of the new mothers as they transitioned into their new roles.

Another learning principle of Bandura's self-efficacy theory is that learning increases with practice and mastery. Lactating mothers reported that increased experience with the 
process, and repeated SSC helped them feel more comfortable with breastfeeding. Listening to the experiences of the women also helped the researcher gain a greater respect for the unique needs of women in the Appalachian culture

At most time intervals, the SSC cohort rates were higher than the comparative cohort rates, yet none of the rates demonstrated significance. This could be influenced by several possible factors. One, the sample and the effect size were small. Sample bias may have resulted from the many mothers who were unable to be reached. A second factor is that certain individual nurses gradually began to introduce some SSC before the policy was formally adopted in April 2014. This project uses a convenience retrospective cohort sample without randomization. If the researcher had selected the comparison cohort a year prior to policy implementation, perhaps a significant difference between the two cohort groups could have been demonstrated, without contamination bias. During the qualitative section, a few mothers in the comparison cohort commented that they had received a "few minutes" of SSC after their infants had been taken to the warmer. This may demonstrate that any SSC may improve breastfeeding outcomes. Bramson et al., 2010 demonstrated a dose dependent relationship between SSC and EBF. EBF rates were proportionally higher for mothers who experienced increased SSC as measured incrementally every 15 minutes through the first hour.

Breastfeeding rates remain low in WV (CDC, 2016). This project demonstrated higher breastfeeding rates as compared to both the nation and the state level for several of the time intervals (see Appendices $\mathrm{H}$ and I). The project breastfeeding duration rates at 3 months and 6 months exceeded the state breastfeeding rates but not the national rates. The project EBF rates at 3 months exceeded both the state and national rates; at 6 months the project rates exceeded the WV rates and almost equaled the national rates around $20 \%$. 
Social support for breastfeeding in West Virginia is needed (CHR, 2014). The qualitative leg of the project indicated that there is strong support for breastfeeding within families. The mothers were asked if they felt supported in the breastfeeding process, $98.5 \%$ of them said that they felt supported in breastfeeding and that most of the support was from their families. Professional support and education from the community are addressed by Steps 2 and 10 of the Ten Steps. This project examined the positive effects of SSC, only one of the Ten Steps, on the population rates.

The findings of the qualitative component agree with Anderzén-Carlsson et al., 2014 in Part II who found that mothers experienced positive and immediate feelings of joy and ecstasy. They also found that these experiences facilitated the growth of self-esteem, assisted the mothers in assuming full responsibility for the child, and enriched the family experience. One mother in the qualitative leg of the project reported, I don't think that I would have bonded with him or breastfed as well without it; another said, it made me feel relaxed and calmer to breastfeed and my husband also did better. These findings also agree with Finigan et al., 2009 who discovered that immediate feelings of bonding, touching, stroking, gazing and coming to know the baby, was viewed as a natural and enriching process, and that mothers wanted it to continue. One mother reported that a bond started right away and it helped us form a greater dependency together; another reported, the more contact you have with your child the more the bond grows. Limitations in the data include: one, the small sample size, perhaps with a larger sample size the breastfeeding rates would have demonstrated significance. Two, a sample bias, the last average grade completed in school was two years beyond high school which is consistent with higher breastfeeding rates, also for two-thirds of the cohort the data is unknown: Three, half of the women didn't take maternity leave and those who took it returned to work around one month. 
Returning to work early has an effect on decreasing breastfeeding duration; with a larger population this could be accounted for in the analysis. Four, at the time of the phone interview, eleven participants in the SSC cohort had not discontinued breastfeeding. If the project had looked beyond 6 months, it would have changed the design and statistical analysis. Suggested areas for further research include: looking at the mother's education level, the length of maternity leave, and fathers' influence on breastfeeding duration and exclusivity.

A hospital can benefit by implementing SSC into policy. Hospital compliance with the Ten Steps of the BFHI in the US remains a challenge, but is increasing (Defrisco et al., 2011). In 2010, fewer than 100 hospitals in the US had received "Baby Friendly" designation, as compared to 19,000 internationally. By 2016, 369 hospitals in the US earned the designation (Baby Friendly, USA, 2016). More research is needed to identify the benefits of all Ten Steps for hospital care in the US. Accomplishing SSC helps move facilities one step closer to achieving this designation and toward achieving the Healthy People 2020 goals of increasing breastfeeding initiation rates, longer exclusivity and duration rates, and improved infant health related outcomes (Defrisco et al., 2011).

Future research can also focus on the effect of SSC on breastfeeding success among mothers with different needs and with women of color. One area needing further research is concerning women who return to work. In two of the studies the authors discussed that mothers returning to work was an influencing factor in the low rate of extended and exclusive breastfeeding before the infant reaches three months (Charpak et al., 2001; Carfoot et al., 2005). Carfoot et al. (2005) mentioned multiple reasons exist for the lack of breastfeeding at 4 months: returning to work, nipple or breast pain, or breastfeeding is "too tiring". In this project between the two groups: $46.5 \%$ of the mothers returned to work, $46 \%$ reported health problems with 
breastfeeding, and $31.5 \%$ reported achieving their desired length of breastfeeding. Lack of evidence exists regarding the diverse factors that affect breastfeeding outcomes when women return to work and the effect on exclusive breastfeeding.

Research also needs to be completed for mothers who are inexperienced in breastfeeding and who undergo a cesarean delivery (Crenshaw et al., 2012). Also more studies are needed that increase the understanding of SSC and duration of breastfeeding. Most of the studies in the literature review were not conducted for greater than one month. More qualitative research is needed to learn about the effects of SSC on mother's lived experiences.

\section{Strategic Plan}

The results of the project suggest that if the hospital continues with the BFHI designation then breastfeeding rates in the community will improve. If implementation of Step Four strengthens breastfeeding rates, then implementing of all Ten Steps may yield greater results, as the literature suggests (Anderzen-Carlsson et al., 2014). Offering continuity of care through BFHI guidelines, and a follow-up plan with the women once they leave the hospital, will help mothers deal with breastfeeding problems once they return home and know what to do allowing them to breastfeed as long as desired. BFHI has incorporated developing community support into the designation process; this helps the facility develop a plan. It is important that the hospital stay involved with the Baby Friendly designation process and see it to completion. This has been done in facilities nationwide and continues to be effective in getting breastfeeding rates to rise and meet national goals and standards. Implementing the Ten Steps into practice continues to occur in settings around the world, and the documentation is increasing showing a rise in breastfeeding rates and a decrease in early childhood illness. Each health care facility has a role to play as a breastfeeding culture emerges. 


\section{Conclusion}

Skin-to-skin contact is an evidence-based guideline and Step Four of the Baby Friendly Ten Steps. This project of retrospective mixed design, in rural Appalachia, has shown that implementing SSC into hospital policy is beneficial to increase breastfeeding rates for low risk healthy mothers who breastfeed their babies to 6 weeks, 3 months, and 6 months. It also has demonstrated that SSC is beneficial to increase EBF breastfeeding rates at 6 weeks and 3 months. Mothers interviewed in the qualitative leg reported that SSC had a positive effect on their breastfeeding and bonding experience in the first months of their babies' life.

This is the first data from WV demonstrating the benefits of one of the Ten Steps and womens lived experiences. Nurses responsible for implementing policy can be encouraged by understanding that evidence based care is needed for follow-up to help women who breastfeed their babies after discharge.

\section{Application of the DNP Essentials}

The DNP Essentials give structure, coherence and purpose to the project. First, the Ten Steps are well grounded in research. A literature search emphasized the importance of the DNP Essential, the Scientific Underpinnings for Practice. This DNP Essential empowered the project leader to see the vision and purpose in the project, collaborate with the leaders and staff of the hospital, and overcome obstacles along the way.

Second, the DNP Essential, Organizational and Systems Leadership for Quality, was a valuable part of the project. The hospital leaders had a growing interest in supporting and promoting breastfeeding within the facility as evidenced by the history of implementing Step Four into policy and applying for Baby Friendly designation. One day the mother-baby unit manager shared a story about how the CEO of the hospital had read about the BFHI in a 
management journal and it helped her later to understand and support the Ten Steps of Baby Friendly.

Third, the DNP Essential the Clinical Scholarship and Analytical Methods for EvidenceBased Practice, is the heart of the project. Applying the evidence based Ten Steps to improve practice is now part of the long-term goals of the facility. The project utilized good clinical scholarship and use of evidence based practice, to promote and support breastfeeding within the patient population served by the hospital. This allows the goals that supported breastfeeding within the facility to be part of a firm foundation and encouraged sustainability in the future. The data and knowledge gained is valuable to the hospital as it continues to serve the breastfeeding needs of this population and maintain Baby Friendly designation.

Fourth, the DNP Essential Information Systems/Technology and Patient Care Technology for the Improvement and Transformation of Health Care was a critical element of this project. Searching for information on 300 patient charts was made easier and manageable by the electronic medical records (EMR) in the hospital. Without the advantage of the EMR, what actually took one month would have taken months in the past. Several times the project leader had to reenter the patient charts for more accurate patient data. The hospital staff was supportive and offered help in the data collection process.

Fifth, the DNP Essential, Health Care Policy for Advocacy in Health Care, was highly important to the implementation of the project. First, in April 2014, the hospital implemented Step 4 SSC into policy. During the fall of 2016, it became committed to a larger policy change and applied for the Baby Friendly designation. Even greater, this small hospital in WV applied for and, upon acceptance of their application for designation, received a scholarship from the CDC Initiative, The unit manager expressed joy upon receipt of the scholarship. The project 
leader remembers this well because it happened at the same time that the relationship with the breastfeeding team began.

Sixth, the project depended upon the DNP Essential, Inter-professional Collaboration for Improving Patient and Population Health Outcomes, at four levels: national, state, local and individual. The national initiative is within the CDC, Empower and Baby Friendly initiative; the state contribution is made through the excellence offered by the WVU professors and professional staff; the local contribution is made by the hospital that is committed to improving maternity care practice; and the individual initiative is offered by the project leader, an advanced nurse-practitioner, midwife, and DNP student, living in WV, pursuing excellence in midwifery and nursing practice.

Seventh, the desire within the team members to improve health care within WV is the driving force for the DNP Essential, Clinical Prevention and Population Health for Improving the Nation's Health. Dedication to offering preventative care through supporting and promoting breastfeeding is a responsibility of professionals in health care working at the systems level. This project leader feels honored to be part of furthering knowledge that promotes breastfeeding success in a breastfeeding population in WV, and where women's voices need to be heard.

Eight, the DNP Essential, Advanced Nursing Practice, is the soul of the project. Midwifery is committed to offering high quality nursing care to women across a life span. Offering quality care is a growth process for both the provider and the health care system. Individual nurse practitioners have a unique opportunity to lead the way and make it happen, especially when they develop their capacity to apply research to practice through a DNP Program. It is rewarding to know that this data can be part of a process that furthers advanced nursing knowledge, applies scientific principles to practice, and improves health care in WV. 
Creativity and ingenuity are needed in managing available resources as the nurse midwife designs a supportive and encouraging environment for the pregnant woman who decides to breastfeed. Trust is needed and promoted by offering the new mother a woman centered philosophy of care, which integrates a belief in self-efficacy and implements the Ten Steps of BFHI into the intrapartum experience. Creating policies in the hospital that support the BFHI guidelines will help Appalachian families participate in a culture of breastfeeding. 


\section{References}

Academy of Breastfeeding Medicine Protocol Committee (2008). ABM clinical protocol \#5: peripartum breastfeeding management for the healthy mother and infant at term revision. Breastfeeding Medicine, 3(2), 129-32

American Academy of Pediatrics (2009). Letter endorsing WHO/UNICEF Ten Steps to successful breastfeeding. Retrieved from www2.aap.org/breastfeeding/ files/pdf/Ten Stepswosig.pdf

American Association of Colleges of Nursing, AACN (2006). The Essentials of Doctoral Education for Advanced Nursing Practice. Advanced Higher Education in Nursing, Washington, DC: Author, 1-28. Website: www.aacn.nche.edu

American Psychological Association (2010). Publication manual of the American Psychological Association (6th edition). Washington, DC: Author

Anderson, G.C., Moore, E., Hepworth, J. \& Bergman, N. (2003). Early skin-to-skin contact for mothers and their healthy newborn infants. Birth, 30(3), 206-207

Anderzén-Carlsson, A., Lamy, Z.C. \& Eriksson, M. (2014). Parental experiences of providing skin-to-skin care to their newborn infant: part 1- a qualitative systematic review. International Journal of Qualitative Studies of Health and Well-being. 13(9), doi:10.3402/qhw.v9.24906

Anderzén-Carlsson, A., Lamy, Z. C., Tingvall, M. \& Eriksson, M. (2014). Parental experiences of providing skin-to-skin care to their newborn infant: part 2- A qualitative metasynthesis. International Journal of Qualitative Studies on Health and Well-Being, 13(9), doi: 10.3402/qhw.v9.24907 
Baby Friendly, USA (2015). The guidelines and evaluation criteria. Retrieved from https://www.babyfriendlyusa.org/get-started/the-guidelines-evaluation-criteria

Bandura, A. (1986). Scope of self-efficacy theory. Journal of Social and Clinical Psychology, $4,359-373$

Bandura, A. (1982). Self-efficacy mechanism in human agency. American Psychologist, 37, $122-147$

Bandura, A. (1992). Self -efficacy mechanism in psychobiologic functioning. Self-efficacy: Thought Control of Action. Retrieved from https://books.google.com/books?hl=en\&lr= $\& \mathrm{id}=\mathrm{DjLJAwAAQBAJ} \& o \mathrm{i}=$ fnd\&pg=PA355\&dq=4+principles+of + bandura + self + efficacy\&ots=nSXmQh-4V0\&sig=HMBadvNKy7G1GIJf6-j_P15jSKA\#v=onepage\&q= 4\%20principles $\% 20$ of $\% 20$ bandura $\% 20$ self $\% 20$ efficacy $\& \mathrm{f}=$ true

Bartick, M. \& Reinhold, A. (2010). The burden of suboptimal breastfeeding in the United States: a pediatric cost analysis. Pediatrics, 125(5), e1048-1056. doi:10.1542/peds.2009-1616

Baumgarder, D.J., Muehl, P., Fischer, M. \& Pribbenow, B. (2003). Effect of labor epidural anesthesia on breast-feeding of healthy full term newborns delivered vaginally. Journal of the American Board of Family Practice, 16(1), 7-13

Behringer, B \& Fridell, G.H. (2006). Appalachia: where place matters in health. Centers for Disease Control and Prevention. Retrieved from www.cdc.gov/pcd/issues/2006/oct / 060067.htm

Bigelow, A. (2012). Effect of mother/infant skin-to-skin contact on postpartum depressive symptoms and maternal physiological stress. Journal of Obstetrics, Gynecology and Neonatal Nursing, 41(3), 369-382 
Blomquist, H.K., Jonsbo, F., Serenius, F., \& Persson, L.A. (1994). Supplementary feeding in the maternity ward shortens the duration of breast feeding. Acta Paediatrics, 83(11), $1122-1126$

Bramson, L., Lee, J.W., Moore, E., Montgomery, S., Neish, C., Bahjri, K., \& Melcher, C.L (2010). Effect of early skin-to-skin mother--infant contact during the first 3 hours following birth on exclusive breastfeeding during the maternity hospital stay. Journal of Human Lactation, 26(2), 130-7. doi: 10. 0890334409355779

Breastfeeding Center of Ann Arbor (2014). Cost of formula feeding. Retrieved from http://bfcaa.com/cost-of-formula-feeding

Canadian Institute of Health Research (2009). Appraisal of guideline for research and evaluation: Agree II Instrument. Retrieved from http://www.agreetrust.org

Carfoot, S., Williamson, P., \& Dickson, R. (2005). A randomized controlled trial in the north of England examining the effects of skin-to-skin care on breast feeding. Midwifery, 2l(1), $71-79$

Cattaneo, A., Buzzetti, R. (2001). Effect on rates of breast feeding of training for the Baby Friendly Hospital Initiative. British Medical Journal, 323(7325), 1358-1362

Centers for Disease Control and Prevention (2013). Strategies to Prevent Obesity and Other Chronic Diseases: The CDC Guide to Strategies to Support Breastfeeding Mothers and Babies. Atlanta: U.S. Department of Health and Human Services, 3-10

Center for Disease Control (2014). Breastfeeding Report Card for 2014. Retrieved from http://www.cdc.gov/breastfeeding/data/reportcard

Center for Disease Control (2016). Breastfeeding report card for 2016. Retrieved from https://www.cdc.gov/breastfeeding/pdf/2016breastfeedingreportcard.pdf 
Charpak, N., Ruiz-Peláez, J.G., Figueroa de, C.Z. \& Charpak, Y. (2001). A randomized, controlled trial of kangaroo mother care: results of follow-up at 1 year of corrected age. Pediatrics, 108 (5), 1072-9

Chien, L.Y. \& Tai, C.J. (2007). Effect of delivery method and timing of breastfeeding initiation on breastfeeding outcomes in Taiwan. Birth, 34(2), 123-130.

Chung, M., Raman, G., Chew, P., Magula, N., DeVine, D., Trikalinos. T. \& Lau J. (2007). Breastfeeding and maternal and infant health outcomes in developed countries. Evidence Report/Technology Assessment. Retrieved from http://www.ahrq.gov/downloads/pub /evidence/ pdf /brfout/brfout.pdf

Cleveland, A.P. \& McCrone, S. (2005). Development of the breastfeeding Personal Efficacy Beliefs Inventory: A Measure of Women's Confidence about Breastfeeding. Journal of Nursing Management, 13(2), 115-127.

County Health Rankings (2014). Robert Woods Johnson foundation. Retrieved from http://www.countyhealth rankings.org/app/west-virginia/2014/measure/outcomes/1/map

Coyne, C.A., Demian-Popescu, C. \& Friend, D. (2006). Social and cultural factors influencing health in southern West Virginia: a qualitative study. Preventing Chronic Disease. Retrieved from http://www.cdc.gov/pcd/issues/2006/oct/06_0030.htm

Crenshaw, J.T., Cadwel, 1. K., Brimdyr, K., Widström, A.M., Svensson, K., Champion, J.D,... Winslow, E. H. (2012). Use of a video-ethnographic intervention (PRECESS Immersion Method) to improve skin-to-skin care and breastfeeding rates. Breastfeeding Medicine, 7(2), 69-78. doi: 10.1089/bfm.2011.0040 
Dewey, K.G., Nommsen-Rivers, L.A., Heinig, M.J. \& Cohen, R.J. (2003). Risk factors for suboptimal infant breastfeeding behavior, delayed onset of lactation, and excess neonatal weight loss. Pediatrics, 112(1), 607-619

DiFrisco, E., Goodman, K.E., Budin, W.C., Llilienthal, M.W., Kleinman, A. \& Holmes, B. (2011). Factors associated with exclusive breastfeeding 2 to 4 weeks following discharge from a large, urban, academic medical center striving for Baby-Friendly designation. Journal of Perinatal Education, 20(1), 28-35

DiGirolamo, A., Grummer Strawn L. \& Fein, S. (2008). Effect of maternity-care practices on breastfeeding. Pediatrics, 122(2), S43-S49

Donnelly, A., Snowden, H.M., Renfrew, M.J. \& Woolridge, M.W. (2000). Commercial hospital discharge packs for breastfeeding women. Cochrane Database of Systematic Reviews, (2), CD002075

Dumas, L., Lepage, M., Bystrova, K., Matthiesen, A., Welles-Nystrom, B. \& Widstrom, A. (2013). Influence of skin-to-skin contact and rooming-in on early mother-infant interaction: a randomized controlled trial. Clinical Nursing Research, 22(3), 310-336

Excamilla, R. P., Martinez, J.L. \& Segura-Pérez, S. (2016). Impact of the Baby-Friendly Hospital Initiative on breastfeeding and child health outcomes: a systematic review. Maternal \& Child Nutrition, 12, 402-417

Fairbank, L., O'Meara, S., Renfrew, M.J., Woolridge, M., Sowden, A.J. \& Lister-Sharp, D. (2000). A systematic review to evaluate the effectiveness of interventions to promote the initiation of breastfeeding. Health Technology Assessment, 4(25), 1-171 
Finnigan, V. (2009). 'I just wanted to love, hold him forever': women's lived experience of skin-to-skin contact with their baby immediately after birth. Royal College of Midwives, $1,1-20$

Galson, S. (2009). Surgeon General's Perspectives: The 25th anniversary of the Surgeon General's workshop on breastfeeding and human lactation. Public Health Reports, 124, $356-358$

Holmes, A.V., Yerdon, A.M. \& Maya, B. (2013). Association for Breastfeeding Medicine clinical protocol \#5: peripartum breastfeeding management for the healthy mother and infant at term, revision 2013. Breastfeeding Medicine, 8(6), 469-473. doi:10.1089/ bfm.2013.9979

International Lactation Consultant Association (2014). Clinical guidelines for the establishment of exclusive breastfeeding. US: ILCA

Ip, S., Chung M. \& Raman, G. (2007). Breastfeeding and maternal and infant health outcomes in developed countries. Evidence Report for Technological Assessment, (153), 1-186

Kramer, M.S., Chalmers, B. \& Hodnett, E.D. (2001). Promotion of breastfeeding intervention trial (PROBIT): a randomized trial in the republic of Belarus. Journal of the American Medical Association, 285(4), 413-420

Larrabee, J.H. (2009). Nurse to Nurse: Evidence-Based Practice. New York: McGraw-Hill Linares, A.M., Wambach, K., Rayens, M.K., Wiggins, A., Coleman, E. \& Dignan, M.B.J. (2016). Modeling the influence of early skin-to-skin contact on exclusive breastfeeding in a sample of Hispanic immigrant women. Minor Health, March11, [Epub ahead of print), PMID: 2696961 
Ludington-Hoe, S. (2015). Skin-to-skin contact: a comforting place with comfort food. American Journal of Maternal Child Nursing, 40(6), 359-366

Mahmood, I., Jamal, M., \& Khan, N. (2011). Effect of mother-infant early skin-to-skin contact on breastfeeding status: a randomized controlled trial. Journal of College Physicians Surgeons \& Pak, 21(10), 601-605. doi:10.2011/JCPSP.601605

Merewood, A., Patel, B., Newton, K.N., MacAuley, L.P., Chamberlain, L.B., Francisco, P. \& Mehta, S.D. (2007). Breastfeeding duration rates and factors affecting continued breastfeeding among infants born at an inner-city US Baby-Friendly hospital. Journal of Human Lactation, 23(2), 157-64

Merten, S., Dratva, J. \& Ackermann-Liebrich, U. (2005). Do baby-friendly hospitals influence breastfeeding duration on a national level? Pediatrics, 116(5), e702-8

Mikiel-Kostyra, K., Mazur, J., \& Boltruszko, I. (2002). Effect of early skin-to-skin contact after delivery on duration of breastfeeding: a prospective cohort study. Acta Paediatrica, 91(12), 1301-1306. doi: 10.1111/j.1651-2227.2002.tb02824.x

Moore, E.R. \& Anderson, G.C. (2007). Randomized controlled trial of very early mother-infant skin-to-skin contact and breastfeeding status. Journal of Midwifery \& Women's Health, $52(2), 116-25$

Moore, E.R., Anderson, G.C. \& Bergman, N. (2007). Early skin-to-skin contact for mothers and their healthy newborn infants. Cochrane Database of Systematic Reviews, (3), CD003519

Moore, E. R., Anderson, G. C., Bergman, N. \& Dowswell, T. (2012). Early skin-to-skin contact for mothers and their healthy newborn infants. Cochrane Database of Systematic Reviews. doi:10.1002/14651858.CD003519.pub3 
National Guideline Clearinghouse (2008). Peripartum breastfeeding management for the healthy mother and infant at term (NGC Publication No.13406). Retrieved from http:// www,guideline.gov/popups/printView.asp

National Conference of State Legislatures (2016). Breastfeeding state laws, WV HB4335. Retrieved from http://ncsl.org

Nyqvist, K.H., Anderson, G.C., Bergman, N., Cattaneo, A., Charpak, N., Davanzo, Widström, A.M. (2010). Towards universal kangaroo mother care: recommendations and report from the first European conference and seventh international workshop on kangaroo mother care. Acta Paediatrics, 99(6), 820-6. doi: 10.1111/j.1651-2227.2010.01787

Okan, F. (2010). Analgesic effects of skin-to-skin contact and breastfeeding in procedural pain in healthy term neonates. Paediatrics, 30(2), 119-128

Oliviera, V., Frazao, E. \& Smallwood, A. (2015). The WIC program: background, trends, and economic issues. Economic Information Bulletin, 134, 1-81.

Palmér, L., Carlsson, G., Mollberg, M. \& Nyström, M. (2010). Breastfeeding: An existential challenge-women's lived experiences of initiating breastfeeding within the context of early home discharge in Sweden. International Journal of Qualitative Studies on Health and Well-Being, 5(3). doi: 10.3402/qhw.v5i3.5397

Perez-Rios, N., Ramos-Valencia, G. \& Ortiz, A.P. (2008). Cesarean delivery as a barrier for breastfeeding initiation: the Puerto Rican experience. Journal of Human Lactation, 24(3), 293-302

Perry, S.E., Hockenberry, M.J., Lowdermilk, D.L., Wilson, D. (2010). Newborn nutrition and feeding. In Barrera, P.F., Editor (4th Ed.). Maternal child nursing care. Maryland Heights, Missouri: Mosby/Elsevier 
Petrova, A., Hegyi, T. \& Mehta, R. (2007). Maternal race/ethnicity and one-month exclusive breastfeeding in association with the in-hospital feeding modality. Breastfeeding Medicine, 2(2), 92-98

Philipp, B.L., Merewood, A. \& Miller, L.W. (2001). Baby-friendly hospital initiative improves breastfeeding initiation rates in a US hospital setting. Pediatrics, 108(3), 677-681

Polit, D.F. \& Beck, C.T. (2012). Nursing research: Generating and assessing evidence for nursing practice (8th edition). Philadelphia: Lippincott Williams \& Wilkins.

Porter, R.H. (2004). The biological significance of skin-to-skin contact and maternal odors. Acta Paediatrics, 93(12), 1560-1562

Procianoy, R.S., Fernandes-Filho, P.H, Lazaro, L. \& Sartori, N.C. (1984). Factors affecting breastfeeding: the influence of caesarean section. Journal of Tropical Pediatrics, 30(1), $39-42$

Redshaw, M., Hennegan, J. \& Kruske, S. (2014). Holding the baby: early mother-infant contact after childbirth and outcomes. Midwifery, 30(5), e177-187

Reynolds F. (2010). The effects of maternal labor analgesia on the fetus. Baillière's Best Practices in Research in Clinical Obstetrics \& Gynecology, 24(3), 289-302

Righard, L., Alade, M.O. (1990). Effect of delivery room routines on success of the first breastfeed. Lancet, 336(8723), 1105-1107

Riordan, J. \& Auerback, K.G. (1993). Tides in breastfeeding practice, breastfeeding and human lactation. Boston and London: Jones and Bartlett.

Rosenberg, K.D., Eastham, C.A., Kasehagen, L.J. \& Sandoval, A.P. (2008). Marketing infant formula through hospitals: the impact of commercial hospital discharge packs on breastfeeding. American Journal of Public Health, 98(2), 290-295 
Rosenberg, K.D., Stull, J.D., Adler, M.R., Kasehagen, L.J. \& Crivelli-Kovach A. (2008). Impact of hospital policies on breastfeeding outcomes. Breastfeeding Medicine, 3(2), $110-116$

Schwarzer, R. (1992). Self-efficacy in the adoption and maintenance of health behaviors: theoretical approaches and a new model. Retrieved from https://books.google.com /books?hl =en\&lr=\&id=DjLJAwAAQBAJ\&oi=fnd\&pg=PA355\&dq=4+principles+of +bandura+self+efficacy\&ots=nSXmQh-4V0\&sig= HMBadvNKy7G1GIJf6-j_Pl5Jska $\# \mathrm{v}=$ onepage $\& \mathrm{q}=4 \% 20$ principles $\% 20 \mathrm{of} \% 20 \mathrm{bandura} \% 20$ self $\% 20$ efficacy $\& \mathrm{f}=$ true

Scottish Intercollegiate Guidelines Network. (2013). Critical appraisal: notes and checklists. Retrieved from http://www.sign.ac.uk/methodology/checklists.html

Srivastava, S. (2014). Effect of very early skin to skin contact on success at breastfeeding and preventing early hypothermia in neonates. Indian Journal of Public Health, 58(1), $22-26$

St. Fleur, R. \& Long (2016). Breastfeeding and culture: perceptions, attitudes, \& approaches for effective care, Empower Breastfeeding Initiative. Retrieved from http://empowerbreastfeeding.org

Stuebe, A. (2009). The risks of not breastfeeding for mothers and infants. Reviews in Obstetrics \& Gynecology, 2(4), 222-231

Thukral, A., Sankar, M.J., Agarwal, R., Gupta, N., Deorari, A.K., Paul, V.K. (2012). Early skinto-skin contact and breast-feeding behavior in term neonates: a randomized controlled trial. Neonatology, 102(2), 114-9. doi: 10.1159/000337839

United States Breastfeeding Committee (2016). Implementing the Joint Commission perinatal care core measure on exclusive breast milk feeding, 3rd edition. Retrieved from 
http://www.usbreast feeding.org.pdf

United States Institute for Kangaroo Care \& Ludington-Hoe (2011). Kangaroo Care bibliography. Retrieved from www.kangaroocareusa.org

United States Department of Agriculture (2013). Trends in infant formula rebate contracts: implications for the WIC Program. Retrieved from http://www.ers.usda.gov/publications /eib-economic- information-bulletin/eib119.aspx\#VC2_qmddV8E

Varendi, H. \& Porter, R.H. (2001). Breast odor as the only maternal stimulus elicits crawling towards the odor source. Acta Paediatrics, 90(4), 372-375

Weimer, J. (2001). The economic benefits of breastfeeding: a review and analysis. Food Assistance and Nutrition Research Report No. 13, 1-20. Retrieved from http://www.ers.usda.gov/publications/fanrr-food-assistance-nutrition-researchprogram/fanrr13.aspx\#.VBtcesVdXXs

WHO/UNICEF (1990). Protecting, promoting and supporting breastfeeding: the special role of maternity services. A joint WHO/UNICEF Statement (1990). International Journal of Gynecology \& Obstetrics, 31(1), 171-183

WHO/UNICEF (1998). Implementing the Ten Steps to successful breastfeeding. London, England: UNICEF

Wiklund, I., Norman, M., Uvnas-Moberg, K., Ransjo-Arvidson, A.B. \& Andolf, E. (2009). Epidural analgesia: breast-feeding success and related factors. Midwifery, 25(2), e31-38

Witters, D. (2012). Utah poised to be the best U.S. state to live In: West Virginia, Mississippi, and Kentucky in the bottom three. Gallup, Wellbeing. Retrieved from http:// www.gallup.com/poll/ 156449/Utah-Poised-Best-State-Live.aspx WV Free Organization (2013). Teen pregnancy and childbearing in West Virginia. 
Retrieved from http://www.wvfree.org/wp-content/uploads/2013/07

WV Perinatal Partnership (2015). WV hospitals supporting skin-to-skin contact. Retrieved from http://www.wv.perinatal partnership 


\section{Appendix A}

The Ten Steps of the Baby Friendly Hospital Initiative

Baby-Friendly hospitals and birthing facilities must adhere to the Ten Steps to receive, and retain, a Baby-Friendly USA designation.

1. Have a written breastfeeding policy that is routinely communicated to all health care staff.

2. Train all health care staff in the skills necessary to implement this policy

3. Inform all pregnant women about the benefits and management of breastfeeding.

4. Help mothers initiate breastfeeding within one hour of birth.

5. Show mothers how to breastfeed and how to maintain lactation, even if they are separated from their infants.

6. Give infants no food or drink other than breast-milk, unless medically indicated.

7. Practice rooming in - allow mothers and infants to remain together 24 hours a day.

8. Encourage breastfeeding on demand.

9. Give no pacifiers or artificial nipples to breastfeeding infants.

10. Foster the establishment of breastfeeding support groups and refer mothers to them on discharge from the hospital or birth center.

Ref: Baby Friendly, USA (2015) 


\section{Appendix $B$}

Step Four, Hospital Infant Feeding Policy

STEP 4: HELP MOTHERS initiate breastfeeding within one hour of birth.

DEFINITION of skin-to-skin contact (SSC): SSC is defined as occurring when the provider places the naked baby in a prone position against the mother's skin, on her upper torso or abdomen, immediately after birth; allowing for continuous and uninterrupted SSC as a part of routine care. The infant will be dressed in no more than a diaper and hat.

TIMEFRAME of mothers planning, versus not planning, to breastfeed: All mothers will experience skin-to-skin care within 5 minutes after birth regardless of feeding choice.

MOTHERS WITH VAGINAL DELIVERIES: Will experience continuous uninterrupted SSC after birth and until completion of the first feeding. If not breastfeeding, the infant will experience SSC at least one hour unless there is a medically justifiable reason for delayed contact.

STAFF RESPONSIBILITY during SSC: mother-baby nursing staff will encourage new mothers, of both vaginal and cesarean deliveries, to look for signs and cues of feeding readiness during this first period of contact. The staff nurse will offer help as needed.

IMPLEMENTATION of routine SSC related to newborn procedures: delaying and implementing initial procedures while mother and infant are in the initial SSC will occur until the end of the above designated timeframes. Initial procedures will routinely be performed at bedside of the mother.

DOCUMENTATION: The time when SSC begins and ends will be documented in the infant's chart. If the mother refuses, or if a medical contraindication to SSC exists, this too will be documented in the chart. If an infant is separated for a medical reason, or must be transferred immediately to the special care nursery, then the nursing staff will insure that SSC begin as soon as the mother and infant are medically stable.

SPECIAL CARE NURSERY: provisions for SSC for mothers and babies who are separated after birth due to medical necessity: Mothers will report that they had the opportunity to practices SSC as soon as the infant is medically considered ready for such contact, unless there are justifiable medical reasons why they should not.

DOCUMENTATION: include medical reason and evidence based reasons for separation and/or residence in the special care nursery. 
Appendix $C$

4-D Pathway to Baby-Friendly Designation

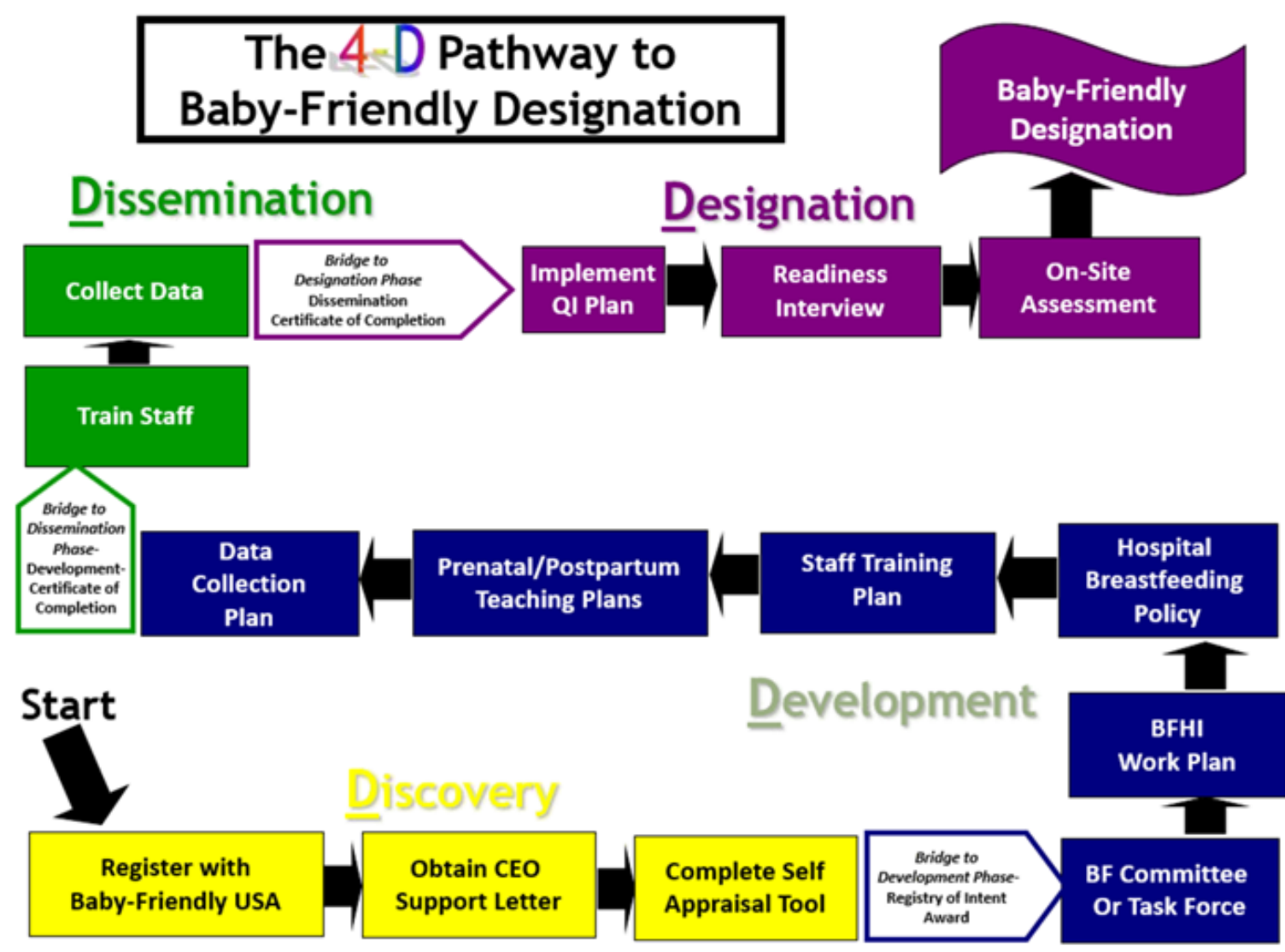

For guidance on how Baby-Friendly USA evaluates these steps, please refer to the BabyFriendly Hospital Initiative Guidelines and Evaluation Criteria, available at babyfriendlyusa.org. The EMPower initiative helps hospitals improve infant feeding policies, training and practices along Baby-Friendly USA's 4-D Pathway. Attainment of Baby-Friendly USA designation requires that your hospital or birthing center meets specific benchmarks for all of the Ten Steps throughout the 4-D Pathway. The 4 "D"s are: D1 Discovery, D2 Development, D3 Dissemination, and D4 Designation.

The 4-D Pathway guides hospitals through verification of policies, curriculum, action plans, quality improvement projects, staff training, and competency verification, as well as a readiness interview and an on-site survey. Upon successful completion of this process, as determined by the onsite assessment and a review of the assessment findings by an External Review Board (ERB), the facility will be granted a license to use the Baby-Friendly certification mark. Ref:

Baby Friendly, USA, (2105) 


\section{Appendix D}

Projected Budget Costs

Time

6 man-hours

Research Preparation

IRB Presentation

10 handouts
Supplies

Costs

$\$ 240$

$\$ 10.00$

Anticipate 5 hours to prepare and 1 hour to present.

15 Electronic \& 5 printed surveys

9 man-hours

$\$ 5.00$

$\$ 360$

Anticipate 5 hours to prepare survey questions, 2 hours to have it reviewed and 2 hours to format it electronically and in print.

\section{Data Collection}

Chart Reviews (150)

33 man-hours

$\$ 1,320$

In a 15 min. chart review with 75 charts in each group is because we hope to find 15 continuing to breastfeed at 3 months. We figure we have to call $50 \mathrm{moms}$ to find at least 15 continuing to breastfeeding at 3 months. Total moms $=150$.

Phonecalls

33 man-hours

$\$ 1,320$

In a 20 minute pc, inviting moms to participate in the survey, duration and exclusivity rates will be tabulated, and IRB disclosure conveyed. Total moms $=100$.

Mailing surveys

2.5 man-hours

$\$ 100$

Anticipate $25 \%$ or the surveys will be sent by postal mail; and $90 \%$ survey emailed. Calculating 3 mins to mail and prepare 25 surveys and one minute per email survey.

Returned surveys, tabulations

9 man-hours

$\$ 360$ 
We anticipate a return of $20 \%$ of the surveys, with 5 surveys returned by postal mail and 15 by email. The 5 postal surveys will take one hour to enter each electronically, and the 15 electronic surveys will take 15 mins to enter each of these electronically.

\section{Data Analysis}

Run SPSS

2 man-hours

Free

Statistical package for social sciences from WVU.

Run QDA Miner Light or CATMA

2 man-hours

Free

$\$ 80$

Computer assisted qualitative data analysis software available online.

Outcomes Reporting

Report writing

Results shared with 5 managers

24 hours

$\$ 960$

Refreshments

2 hours

$\$ 160$

Poster \& Handouts

$\$ 45$

$\$ 55$

Miscellaneous Supplies (paper, pens, etc.)

$\$ 25$

Phone \& Office - contributed expense

$\$ 0$

TOTALS

122.5 man-hours

$\$ 140$

$\$ 4,910$

*Project Coordinator calculated at $\$ 40.00 / \mathrm{hr}$. 


\section{Appendix E}

\section{Budget Description}

Capstone Budget Plan Form and Justification: SSC \& breastfeeding outcomes

\begin{tabular}{|l|l|l|}
\hline \multicolumn{1}{|c|}{ Budget Categories } & \multicolumn{1}{|c|}{ Personal Funds } & Organizational Contributions \\
\hline ADMINISTRATIVE COSTS & $\$ 4910$ & $\$ 0$ \\
\hline Adminte & & \\
\hline
\end{tabular}

Administrative Justification: This is a retrospective study of Step 4 of the implementation of the Ten Steps at Hospital and the initiation of the Baby Friendly Hospital Initiative. See attached form for breakdown and line items related to administrative costs and time in man-hours.

An average Nurse practitioner/midwife salary $\$ 40 / \mathrm{hr}$. is used for calculations.

\begin{tabular}{l|l|l} 
MARKETING & $\$ 0$ & $\$ 0$
\end{tabular}

Marketing Justification: This is a "sunk" cost and part of the ongoing implementation of Step 4 and Baby Friendly.

EDUCATIONAL MATERIALS/ INCENTIVES

Educational Materials/Incentives Justification: This is a "sunk" cost and part of the ongoing implementation of Step 4 and Baby Friendly.

HOSPITALITY (food, room rentals, etc.)

\section{$\$ 45$}

$\$ 0$

$\$ 0$

Hospitality Justification: Refreshments served when sharing the report and outcomes with the managers.

\begin{tabular}{|c|c|c|}
\hline $\begin{array}{l}\text { PROJECT SUPPLIES (office supplies, } \\
\text { postage, printing, etc.) }\end{array}$ & $\$ 140$ & $\$ 100$ \\
\hline
\end{tabular}

Project Supplies Justification: See itemization and line items on attached form. In kind contributions for phone $\&$ office are included under organizational costs.

\begin{tabular}{|l|l|l|}
\hline TRAVEL EXPENSES & $\$ 0$ & $\$ 0$ \\
\hline \multicolumn{2}{|l|}{ Travel Expenses Justification: nothing incurred } \\
\hline OTHER & $\$ 0$ & $\$ 0$ \\
\hline
\end{tabular}

Other Justification: 


\section{TOTALS}

\section{Financial Plan}

\section{Detailed Budget Description:}

Small grant funds will be used to cover the costs of this project and the man-hours donated by the investigator. This Capstone focusses on Step 4 of the Ten Steps being implemented by SJMH for designation into the Baby Friendly Hospital Initiative. No financial plan beyond the commitment and initial fee to Baby Friendly, USA is incurred by the hospital. This Capstone Project goes beyond the programmed data collected for Baby Friendly to collect outcomes for duration and exclusivity at 6 weeks and 3 months. It also has a qualitative component exploring mother's lived experience with breastfeeding following skin-to-skin contact. 


\section{Appendix $F$}

Phone Interview Script*

My name is Cristina Menking. I am a nurse midwife and doctoral student at WVU. I was given your name and number by ___ Hospital as someone who delivered a healthy baby there within the past couple of years - 2012-2016. The purpose of the project is to evaluate the effect of skin-to-skin contact, at the time of delivery, on infant feeding. I am conducting this project with WVU under the supervision of Dr. Susan McCrone, a professor for a doctoral degree in nursing. Your participation is greatly appreciated and will take about 10 minutes. The interview will ask some questions about you, your baby and your experience with infant feeding or breastfeeding. Would you be willing to participate?

If they say yes? Is this a good time for you to speak? Proceed with the IRB disclosure then the questionnaire.... Or ....If this is not a good time to speak, could we set up a time that I could call you back?

If they say no? Thank you for your time. Would you like a way to contact me for more information?

Your involvement is completely voluntary and will be kept as confidential as possible. All data will be reported as a group. The questions include only numbers, not your name. I will not ask any information that leads back to your identity as a participant. You may skip any question that you do not wish to answer, and you may discontinue at any time.

If you feel that you would like to have more time to answer the questions I can send you a letter through the mail, with return postage paid via an envelope.

Your answers are very important to me as a nurse-midwife and student. If you have any questions, please do not hesitate to contact me at _ phone \#. If you miss me please leave a voice message with the date of your baby's birth and I will call you back.

Thank you for caring to share your time and help with this project.

\footnotetext{
* Approved by WVU IRB
} 


\section{Appendix $G$}

Questionnaire*

\section{Mother's Demographic Questions}

1) What is your baby's birthday?

.... What was your due date?

- Term? Yes No

2) Are you breastfeeding now? Yes No

- Exclusive time breastfed?

○ Total time breastfed?

3) What is your age?

4) What is your race/ ethnicity?

5) What is the last grade that you completed in school?

6) How many children do you have and what are their ages?

Number of children breastfed? For how long?

$\circ \mathrm{G}_{-} \mathrm{P}$

7) Did you attend breastfeeding classes before your baby was born?

$\circ$ Breastfeeding class Yes__ No

8) Did you work after the birth of your baby? Yes No

○ If yes, did you take maternity leave after you delivered?

For how long?

9) Did you have any health problems with this pregnancy? Yes No

- Did they exist before? 


\section{Mother's Qualitative Questions}

10) If you have stopped breastfeeding .... Describe the experience?

11) Did you feel supported by anyone in your breastfeeding experience? Yes No If yes, by whom?

12) Do you have anything you would like to say about your birth, the skin-to-skin experience, and the first memories of seeing and touching your child?

* Approved by WVU IRB 


\section{Appendix $H$}

Duration Breastfeeding Rates Graph

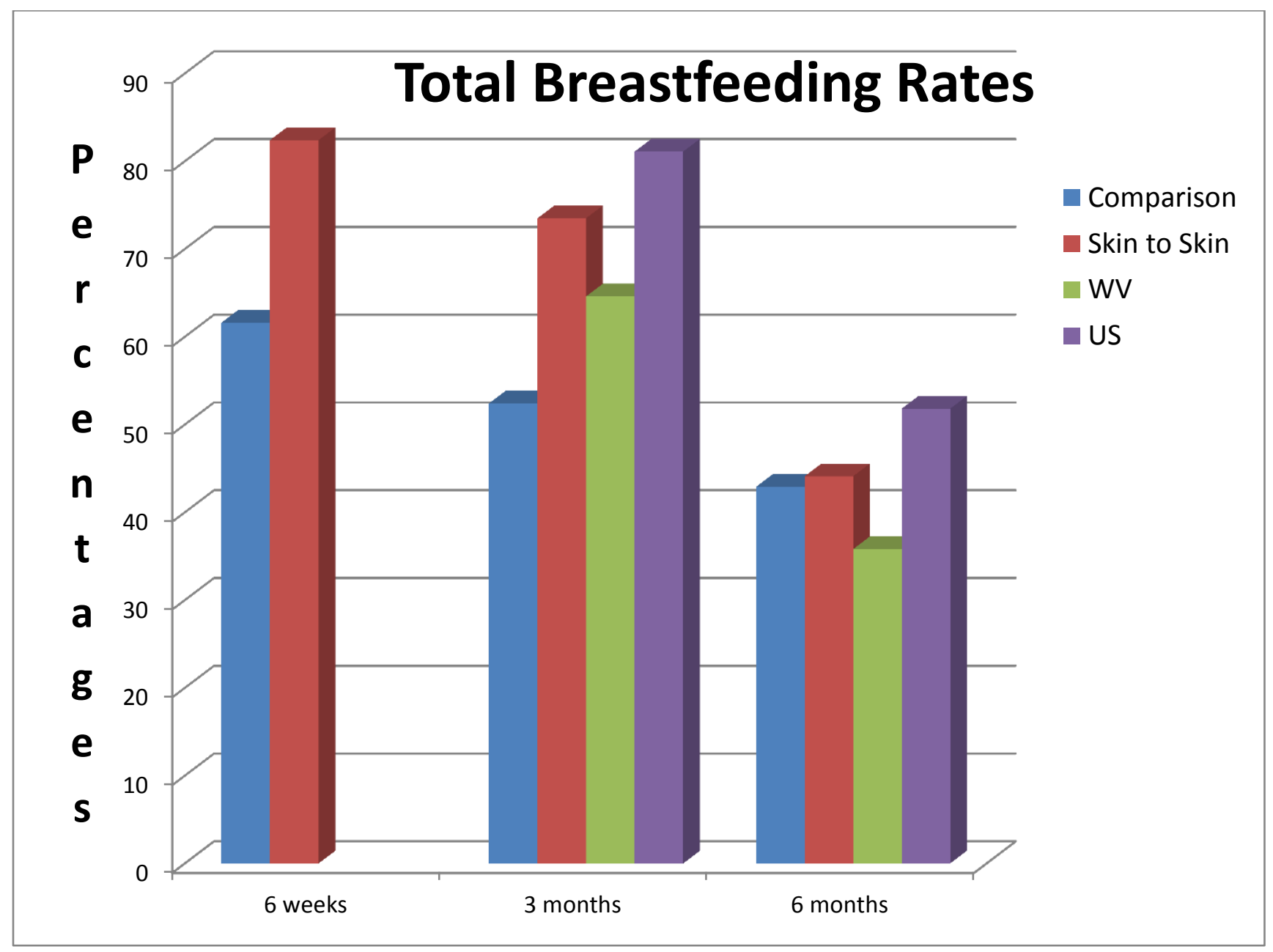




\section{Appendix I}

Exclusive Breastfeeding Rates

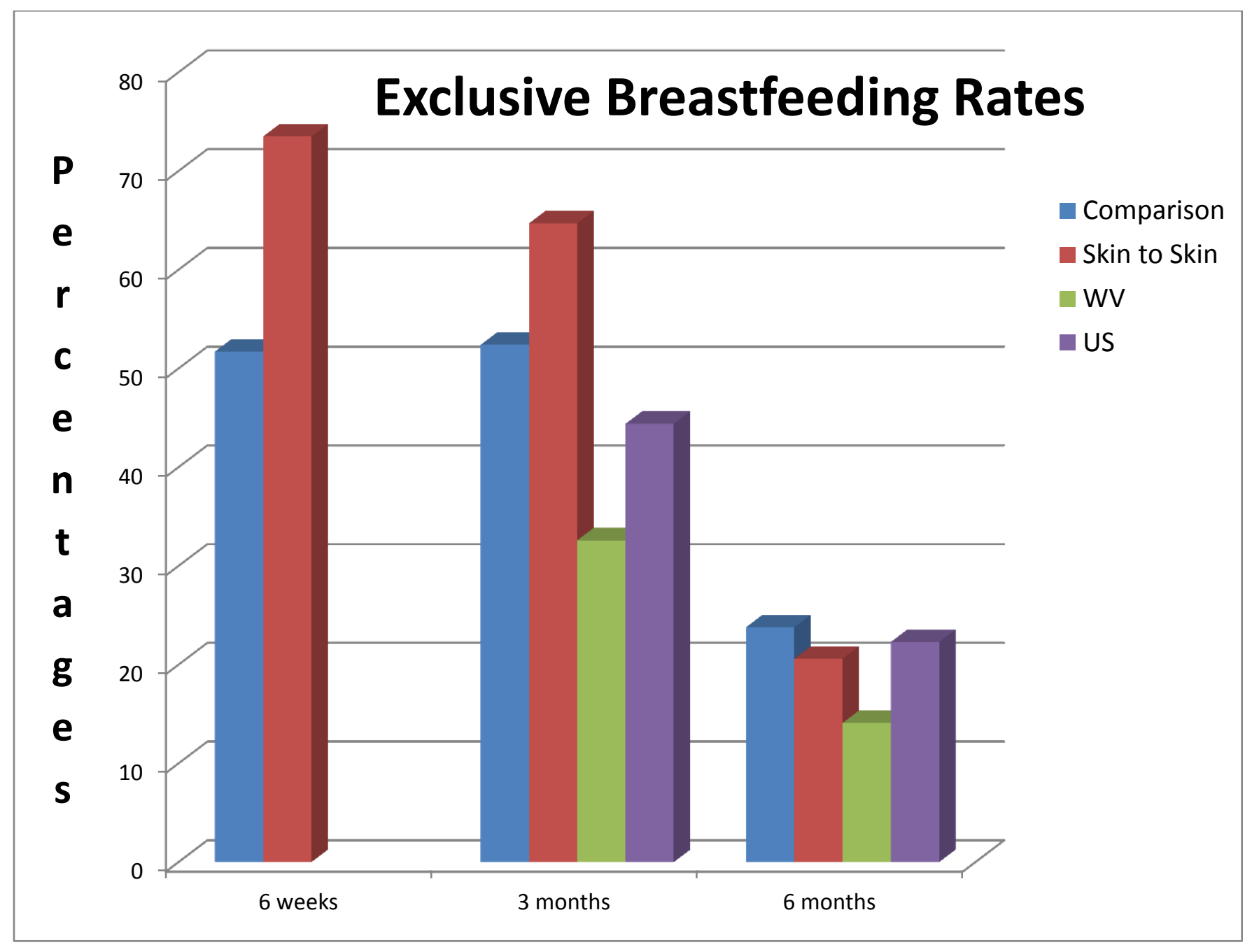


Table 1

Table of Evidence

\begin{tabular}{|c|c|c|c|c|c|}
\hline Citation & Research Aim(s) & Methodology & Design & Results & $\begin{array}{l}\text { Strengths and } \\
\text { Limitations }\end{array}$ \\
\hline $\begin{array}{l}\text { Charpak et al, } \\
2001\end{array}$ & $\begin{array}{l}\text { AIM: } \\
* \text { To assess skin- } \\
\text { to-skin contact } \\
\text { (SSC), } \\
\text { addressed in this } \\
\text { study as } \\
\text { Kangaroo } \\
\text { Mother Care } \\
\text { (KMC), \& the } \\
\text { effect it has on } \\
\text { breastfeeding } \\
\text { (BF) duration \& } \\
\text { pattern. }\end{array}$ & $\begin{array}{l}\text { RCT } \\
\text { N=746 mother- } \\
\text { baby dyads } \\
\text { n= } 382 \text { KMC } \\
\text { group n=364 } \\
\text { TCG (traditional } \\
\text { care group) } \\
\text { Data: } \\
\text { Where? Clinica } \\
\text { San Pedro } \\
\text { Claver hospital } \\
\text { in Bogota, } \\
\text { Colombia } \\
\text { Intervention } \\
\text { group: } * \text { Infants } \\
\text { positioned on } \\
\text { mother's chest } \\
\text { as much as } \\
\text { desired \& kept } \\
\text { SSC for } \\
\text { temperature } \\
\text { stabilization \& } \\
\text { breastfeeding } \\
\text { (BF). *Formula } \\
\text { supplements, } \\
\text { given as needed, } \\
\text { occurred when a } \\
\text { desired weight } \\
\text { was achieved. } \\
\text { Control group: } \\
\text { *Infants kept in } \\
\text { incubators until } \\
\text { they could } \\
\text { regulate their } \\
\text { own temperature } \\
\text { \& met the } \\
\text { desired weight } \\
\text { gain. } \\
* \text { Access }\end{array}$ & $\begin{array}{l}\text { Independent } \\
\text { Variable: } \\
\text { * Early KMC \& } \\
\text { SSC group } \\
\text { Dependent } \\
\text { Variables: } \\
\text { * BF patterns } \\
\text { during follow up } \\
\text { visits at } 1,3,6,9 \\
\& 12 \text { months. } \\
\text { Instruments: } \\
* \text { Hospital \& } \\
\text { clinic records } \\
\text { that contained } \\
\text { the measurement } \\
\text { data from patient } \\
\text { visits. }\end{array}$ & 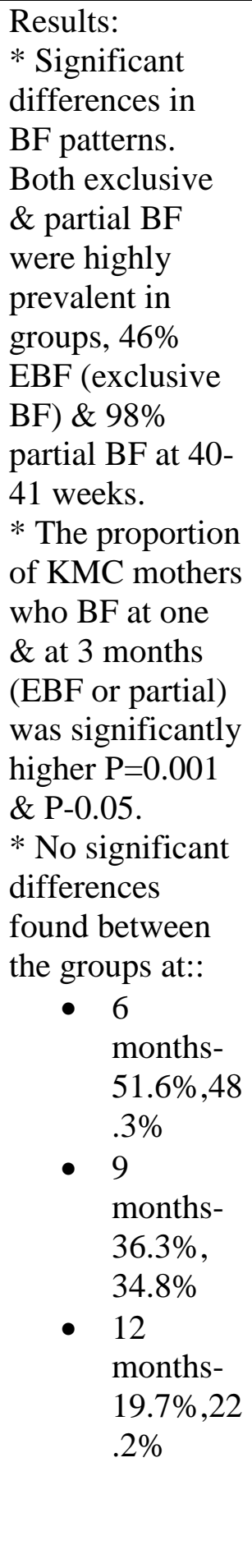 & $\begin{array}{l}\text { Strengths: } \\
* \text { Large sample } \\
\text { size } \\
* \text { Randomization } \\
\text { by four stratified } \\
\text { block lists that } \\
\text { were prepared } \\
\text { from a list of } \\
\text { random numbers } \\
* \text { Power analysis } \\
\text { based on sample } \\
\text { size } \\
* \text { Contamination } \\
\text { bias was } \\
\text { minimized } \\
\text { through follow } \\
\text { up \& scheduling } \\
\text { the two groups } \\
\text { at different times } \\
\text { Limitations: } \\
* \text { Multisite study } \\
* \text { Researchers } \\
\text { tried to control } \\
\text { for this by } \\
\text { insuring there } \\
\text { was not more } \\
\text { than one site per } \\
\text { group. } \\
* \text { Supplementing } \\
\text { the SSC with } \\
\text { formula as } \\
\text { needed is } \\
\text { potentially a } \\
\text { confounder that } \\
\text { could diminish } \\
\text { BF success \& } \\
\text { duration. } \\
* \text { Data obtained } \\
\text { from partial \& }\end{array}$ \\
\hline
\end{tabular}




\begin{tabular}{|c|c|c|c|c|c|}
\hline & & $\begin{array}{l}\text { restricted to } \\
\text { newborns per } \\
\text { hospital routine. }\end{array}$ & & & $\begin{array}{l}\text { EBF rates } \\
\text { combined. }\end{array}$ \\
\hline $\begin{array}{l}\text { Carfoot et al, } \\
2005\end{array}$ & $\begin{array}{l}\text { AIM: } \\
* \text { To examine } \\
\text { the effect of } \\
\text { early skin-to- } \\
\text { skin care (SSC) } \\
\text { between mother } \\
\& \text { infant pair on } \\
\text { the initiation and } \\
\text { duration of } \\
\text { breastfeeding } \\
\text { (BF). }\end{array}$ & $\begin{array}{l}\text { RCT } \\
\text { N=204 mother } \\
\text { \& baby pairs } \\
\mathrm{n}=102 \text { to each } \\
\text { SSC \& CC } \\
\text { (conventional } \\
\text { care) group } \\
\text { Data: } \\
\text { Where? } \\
\text { Warrington } \\
\text { Hospital in } \\
\text { North England } \\
\text { Intervention } \\
\text { group: SSC } \\
\text { began when the } \\
\text { nurse-midwife } \\
\text { placed the baby } \\
\text { between the } \\
\text { mother's breasts } \\
\text { for uninterrupted } \\
\text { contact, a } \\
\text { minimum of } 45 \\
\text { minutes. } \\
\text { Control group: } \\
\text { Babies were } \\
\text { dried \& wrapped } \\
\text { in a towel before } \\
\text { being handed to } \\
\text { the mother or } \\
\text { family member. } \\
\text { Interruption of } \\
\text { contact occurred } \\
\text { for early hospital } \\
\text { procedures. } \\
\text { Participants: } \\
\text { Healthy, } \\
\text { pregnant women } \\
\text { intending to BF, } \\
\text { who planned to } \\
\text { birth at the } \\
\text { hospital, \& had a }\end{array}$ & $\begin{array}{l}\text { Independent } \\
\text { Variable: } \\
\text {-Early SSC after } \\
\text { birth } \\
\text { Dependent } \\
\text { Variables: } \\
\text { Successful BF: } \\
\text {-At initial } \\
\text { contact } \\
\text {-Prior to } \\
\text { discharge -At } 4 \\
\text { months } \\
\text { Instrument: } \\
\text {-IBFAT - Infant } \\
\text { Breastfeeding } \\
\text { Assessment tool, } \\
\text { an assessment of } \\
\text { baby BF } \\
\text { competence } \\
\text { measuring } \\
\text { readiness to } \\
\text { breastfeed, } \\
\text { rooting and hand } \\
\text { movements, and } \\
\text { suckling. } \\
\text { It was amended } \\
\text { to include a } \\
\text { "latching-on" } \\
\text { component }\end{array}$ & 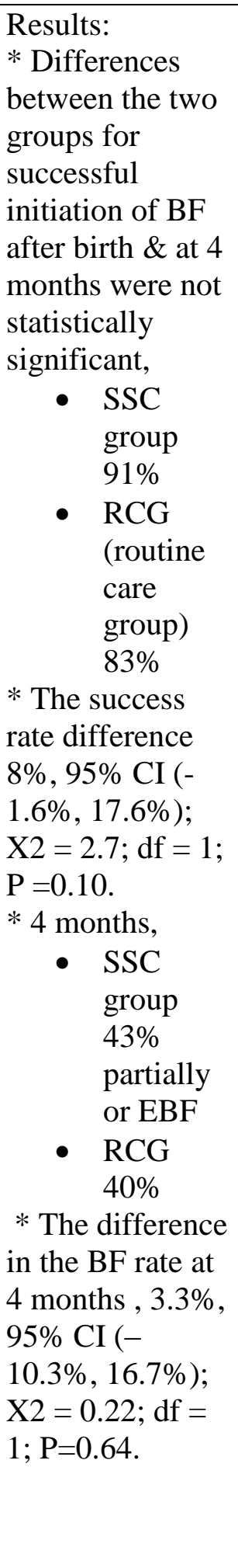 & $\begin{array}{l}\text { Strengths: } \\
\text { * Computer } \\
\text { generated } \\
\text { randomization } \\
\text { list } \\
\text { * Intention to } \\
\text { treat principle } \\
\text { observed } \\
\text { * An additional } \\
\text { measure on } \\
\text { maternal } \\
\text { satisfaction } \\
\text { between the } 2 \\
\text { group was } \\
\text { significant for } \\
\text { maternal } \\
\text { satisfaction \& } \\
\text { preference for } \\
\text { SSC in the } \\
\text { future (P<0.001) } \\
\text { can be valuable } \\
\text { for future } \\
\text { research. } \\
\text { Limitations: } \\
* \text { Interference } \\
\text { from the } \\
\text { researchers in } \\
\text { the intervention } \\
\text { group. } \\
\text { * Participant } \\
\text { bias could have } \\
\text { caused the } \\
\text { overall rates of } \\
\text { successful BF to } \\
\text { be higher than } \\
\text { expected. }\end{array}$ \\
\hline
\end{tabular}




\begin{tabular}{|c|c|c|c|c|c|}
\hline & & $\begin{array}{l}\text { fetus greater } \\
\text { than } 36 \text { weeks' } \\
\text { gestation. }\end{array}$ & & & \\
\hline $\begin{array}{l}\text { Mahmood et al, } \\
2011\end{array}$ & $\begin{array}{l}\text { AIM: } \\
* \text { To assess the } \\
\text { effect of early } \\
\text { skin-to-skin care } \\
\text { (SSC) between } \\
\text { the mother- } \\
\text { infant pair on the } \\
\text { time to initiate } \\
\text { the first } \\
\text { breastfeed (BF), } \\
\text { the time to } \\
\text { effectively BF \& } \\
\text { the amount of } \\
\text { exclusive BF } \\
\text { (EBF) at one } \\
\text { month of age. }\end{array}$ & $\begin{array}{l}\text { RCT } \\
\text { N=183 mother- } \\
\text { baby pairs } \\
\text { n=92 SSC group } \\
\text { n=91 CC group } \\
\text { Data: } \\
\text { Where? } \\
\text { Pakistan } \\
\text { Institute of } \\
\text { Medical } \\
\text { Sciences, } \\
\text { Islamabad } \\
\text { Intervention } \\
\text { group: SSC } \\
\text { group, infants } \\
\text { were dried \& } \\
\text { placed on } \\
\text { mother's } \\
\text { abdomen after } \\
\text { birth; in prone } \\
\text { position between } \\
\text { their breasts. } \\
\text { Uninterrupted } \\
\text { contact \& BF } \\
\text { was allowed for } \\
\text { 45-120 minutes. } \\
\text {-Control group } \\
\text { (CC): Infants } \\
\text { shifted to the } \\
\text { radiant warmer } \\
\text { immediately } \\
\text { after cutting the } \\
\text { cords. They } \\
\text { were cleaned \& } \\
\text { wrapped with } \\
\text { pre-warmed } \\
\text { sheets First feed } \\
\text { was started } \\
\text { when mothers } \\
\text { were ready. }\end{array}$ & $\begin{array}{l}\text { Independent } \\
\text { Variable: } \\
\text { * Early SSC } \\
\text { after birth } \\
\text { Dependent } \\
\text { Variables: } \\
\text { * Time to } \\
\text { initiate first BF } \\
\text { (minutes) } \\
\text { * Time to } \\
\text { effective BF } \\
\text { (minutes) } \\
\text { * Time to } \\
\text { effectively BF } \\
\text { * Exclusive \& } \\
\text { partial BF @ } \\
\text { one month } \\
\text { Instrument: } \\
\text { * IBFAT tool- } 3 \\
\text { research } \\
\text { assistants \& } \\
\text { physicians were } \\
\text { trained in its } \\
\text { use' } \\
* \text { Time to } \\
\text { initiate first BF } \\
\text { was measured } \\
\text { minutes } \\
* \text { Time to } \\
\text { effectively BF } \\
\text { was measured } \\
\text { in minutes from } \\
\text { birth until start } \\
\text { of } 3 \text { consecutive } \\
\text { BF } \\
\text { * Exclusivity at } \\
\text { one month } \\
\text { postpartum was } \\
\text { measured by the }\end{array}$ & $\begin{array}{l}\text { Results: } \\
\text { * Early SSC } \\
\text { significantly } \\
\text { enhanced the } \\
\text { success of BF } \\
\text { initiation \& } \\
\text { continuation of } \\
\text { EBF until one } \\
\text { month of age. } \\
* \text { Time to } \\
\text { initiate the first } \\
\text { feed \& the time } \\
\text { to effective BF. } \\
* \text { The first BF } \\
\text { was } 26.25 \% \\
\text { more successful } \\
\text { in the SSC group } \\
\text { (58.8\% as } \\
\text { compared to } \\
32.5 \% \text { in CC } \\
\text { group with a p- } \\
\text { value of } 0.001 \text { ). } \\
* \text { In the SSC } \\
\text { group, the mean } \\
\text { time to initiate } \\
\text { the } \\
\text { first BF was } \\
61.6 \text { minutes } \\
\text { shorter than in } \\
\text { the CC group } \\
\text { (40.62 vs. } \\
101.88 ; \text { p < } \\
0.001 \text { ). } \\
* \text { The mean time } \\
\text { to achieve } \\
\text { effective BF was } \\
207 \text { minutes } \\
\text { earlier in the } \\
\text { SSC group } \\
\text { (149.69 vs. } \\
357.50 ; \text { p } \\
\text { a }\end{array}$ & $\begin{array}{l}\text { Strengths: } \\
\text { * Study was } \\
\text { randomized with } \\
\text { premixed sealed } \\
\text { envelopes } \\
\text { * Pilot study was } \\
\text { conducted to } \\
\text { calculate the } \\
\text { sample size \& } \\
\text { power of } 90 \% \text {. } \\
\text { * Outcomes } \\
\text { measured in a } \\
\text { standard, valid } \\
\& \text { reliable way. } \\
\text { * High quality } \\
\text { instruments were } \\
\text { used in the } \\
\text { study. } \\
* \text { Researchers \& } \\
\text { physicians were } \\
\text { trained in the use } \\
\text { of the tool. } \\
\text { Limitations: } \\
* \text { Follow-up at } \\
\text { one month is a } \\
\text { small time } \\
\text { interval \& not in } \\
\text { accordance with } \\
\text { national \& } \\
\text { international } \\
\text { guidelines that } \\
\text { recommend } 6 \\
\text { months of } \\
\text { fulltime BF. } \\
\text { Assessing long- } \\
\text { term exclusive } \\
\text { BF needs further } \\
\text { research. } \\
* \text { Risk for } \\
\text { cultural bias }\end{array}$ \\
\hline
\end{tabular}




\begin{tabular}{|c|c|c|c|c|c|}
\hline & & $\begin{array}{l}\text { Participants: } \\
\text { Healthy full } \\
\text { term mothers } \\
\text { anticipating a } \\
\text { normal vaginal } \\
\text { delivery with the } \\
\text { intention of } \\
\text { exclusive BF for } \\
\text { at least one } \\
\text { month. }\end{array}$ & $\begin{array}{l}\text { index of BF } \\
\text { status (IBS) as } \\
\text { full, partial or } \\
\text { token. }\end{array}$ & $\begin{array}{l}0.001) . \\
* \text { In the SSC } \\
\text { group } 85.3 \% \\
\text { infants were } \\
\text { exclusively } \\
\text { BF at one month } \\
\text { as compared to } \\
65.7 \% \text { in the CC } \\
\text { group }(\mathrm{p}=0.025 .\end{array}$ & $\begin{array}{l}\text { may be a } \\
\text { confounder due } \\
\text { to diverse } \\
\text { customs related } \\
\text { to unique health } \\
\text { care practices in } \\
\text { different } \\
\text { countries. } \\
* \text { Potential } \\
\text { confounders } \\
\text { could be found } \\
\text { in that mode of } \\
\text { birth or } \\
\text { medications } \\
\text { given during } \\
\text { birth were not } \\
\text { accounted in the } \\
\text { baseline } \\
\text { characteristics. }\end{array}$ \\
\hline $\begin{array}{l}\text { Thukral et al, } \\
2012\end{array}$ & $\begin{array}{l}\text { AIM: } \\
* \text { To evaluate if } \\
\text { skin-to-skin care } \\
\text { (SSC) improves } \\
\text { breastfeeding } \\
\text { (BF) behavior \& } \\
\text { exclusive BF } \\
\text { (EBF) rates in } \\
\text { term infants at } \\
48 \text { hours \& } 6 \\
\text { weeks of age. }\end{array}$ & $\begin{array}{l}\text { RCT } \\
\text { N=41 mother- } \\
\text { baby pairs } \\
\mathrm{n}=20 \text { SSC group } \\
\mathrm{n}=21 \text { CC group } \\
\text { Data: } \\
\text { Where? All } \\
\text { India Institute of } \\
\text { Medical } \\
\text { Sciences, New } \\
\text { Delhi, India } \\
\text { Intervention } \\
\text { group: Infants in } \\
\text { the SSC group } \\
\text { were placed } \\
\text { prone over the } \\
\text { mother's chest } \\
\text { immediately } \\
\text { after birth; it was } \\
\text { uninterrupted for } \\
2 \text { hours. } \\
\text { Control group: } \\
\text { Conventional } \\
\text { care group, no } \\
\text { other description } \\
\text { offered. }\end{array}$ & $\begin{array}{l}\text { Independent } \\
\text { Variable: } \\
* \text { Early SSC after } \\
\text { birth } \\
\text { Dependent } \\
\text { Variables: } \\
* \text { BF behaviors in } \\
\text { the infant at } 36-48 \\
\text { hours of age. } \\
* \text { EBF rates at } 48 \\
\text { hours \& } 6 \text { weeks } \\
\text { Instruments: } \\
* \text { The Modified } \\
\text { Infant BF (BAT) } \\
\text { tool, successful } \\
\text { BF was defined as } \\
\text { as readiness to BF } \\
\text { with a score of } \geq \\
8 . \\
* \text { Video } \\
\text { recordings \& } \\
\text { analysis of one BF } \\
\text { session at } 36-48 \\
\text { hours. } \\
* \text { Record of } \\
\text { discharge time. }\end{array}$ & $\begin{array}{l}\text { Results: } \\
\text { * Early SSC } \\
\text { significantly } \\
\text { improved } \\
\text { exclusive BF } \\
\text { rate at discharge } \\
\& \text { at } 6 \text { weeks. } \\
\text { * Early SSC } \\
\text { group was more } \\
\text { likely to be EBF } \\
\text { than those in the } \\
\text { control group at } \\
\text { both } 48 \text { hours \& } \\
6 \text { weeks (RR: } \\
2.5,95 \% \text { CI-1.4 } \\
\& 3.2, \& 95 \% \\
\text { CI 1.6-6.3, } \\
\text { respectively, } \\
\text { p=0.001 at both } \\
\text { times). }\end{array}$ & $\begin{array}{l}\text { Strengths: } \\
* \text { Randomization } \\
\text { with allocation } \\
\text { concealment, the } \\
\text { outcome } \\
\text { assessment team } \\
\text { blinded \& } \\
\text { consisted of a } \\
\text { group of } 3 \\
\text { independent } \\
\text { masked } \\
\text { observers. } \\
\text { * Measurement } \\
\text { tool is respected } \\
\text { in other SSC } \\
\text { literature. } \\
\text { * Outcomes } \\
\text { measured in a } \\
\text { standard, valid } \\
\& \text { reliable way. } \\
\text { Limitations: } \\
* \text { A one-time } \\
\text { assessment of a } \\
\text { BF session. } \\
* \text { The absence of }\end{array}$ \\
\hline
\end{tabular}




\begin{tabular}{|c|c|c|c|c|c|}
\hline & & $\begin{array}{l}\text { Participants: } \\
\text { Term infants } \\
\text { delivered by } \\
\text { normal vaginal } \\
\text { delivery during } \\
\text { day shift all days } \\
\text { of the week. } \\
\text { Mothers in both } \\
\text { groups received: } \\
\text { support for BF } \\
\text { initiation, } \\
\text { advised to EBF } \\
\text { until } 6 \text { months of } \\
\text { age, discouraged } \\
\text { from giving } \\
\text { supplements }\end{array}$ & & & $\begin{array}{l}\text { data, a } \\
\text { description of } \\
\text { the CC group \& } \\
\text { how the } \\
\text { measurement } \\
\text { data was } \\
\text { obtained at } 6 \\
\text { weeks. } \\
* \text { The power of } \\
\text { the study could } \\
\text { be limited due to } \\
\text { small sample } \\
\text { size. }\end{array}$ \\
\hline $\begin{array}{l}\text { Moore et al, } \\
2007\end{array}$ & $\begin{array}{l}\text { AIM: } \\
* \text { To evaluate } \\
\text { the effect of } \\
\text { early skin-to- } \\
\text { skin care (SSC) } \\
\text { on initial } \\
\text { breastfeeding } \\
\text { (BF) success \& } \\
\text { on exclusive BF } \\
\text { (EBF) in the first } \\
\text { month of life. }\end{array}$ & $\begin{array}{l}\text { RCT } \\
\text { N= } 20 \text { maternal- } \\
\text { infant pairs } \\
\text { N=10 SSC } \\
\text { group } \\
\text { N=10 CC group } \\
\text { Data: } \\
\text { Where? } \\
\text { Vanderbilt } \\
\text { Univ., Nashville } \\
\text { Tenn. } \\
\text { Intervention } \\
\text { group: Infant } \\
\text { was given SSC } \\
\text { on the mother's } \\
\text { abdomen or } \\
\text { chest during the } \\
\text { first minute post } \\
\text { birth, after } \\
\text { drying it is } \\
\text { covered with a } \\
\text { pre-warmed } \\
\text { blanket, for } 2 \\
\text { hours. } \\
\text { Control group: } \\
\text { Infant was } \\
\text { shown briefly to } \\
\text { its mother }\end{array}$ & $\begin{array}{l}\text { Independent } \\
\text { Variable: } \\
\text { Early SSC after } \\
\text { birth } \\
\text { Dependent } \\
\text { Variables: } \\
\text { * Time to BF } \\
\text { effectively } \\
\text { * EBF } \\
\text { Instrument: } \\
\text { * The IBFAT, } \\
\text { Infant BF, } \\
\text { Assessment tool } \\
\text { * The infant BF } \\
\text { log that records } \\
\text { the IBFAT } \\
\text { scores over time, } \\
\text { * The IBS, } \\
\text { which assesses } \\
\text { the degree of BF } \\
\text { exclusivity. }\end{array}$ & $\begin{array}{l}\text { Results: } \\
* \text { Early SSC } \\
\text { enhances BF } \\
\text { success during } \\
\text { the early } \\
\text { postpartum } \\
\text { period. } \\
* \text { SSC group } \\
\text { achieved } \\
\text { effective } \\
\text { BF sooner } \\
(935 \pm 721 \\
\text { minutes vs } 1737 \\
\pm 1001 ; \mathrm{P}<.04) \text {. } \\
* \text { No significant } \\
\text { differences in } \\
\text { EBF }(1.50 \pm 1.1 \\
\text { vs } 2.10 \pm 2.2 ; \\
\text { P<0.45) or } \\
\text { problems with } \\
\text { BF were found } \\
\text { at one month. }\end{array}$ & $\begin{array}{l}\text { Strengths: } \\
\text { * Randomization } \\
\text { * Power analysis } \\
\text { based on sample } \\
\text { size. } \\
\text { * Measurement } \\
\text { tool is respected } \\
\text { in other SSC } \\
\text { literature. } \\
\text { Limitations: } \\
\text { * Potential } \\
\text { confounders } \\
\text { include no } \\
\text { mention of: } \\
\text { medication taken } \\
\text { in delivery \& its } \\
\text { effect on the } \\
\text { baby, no nurse } \\
\text { offered training } \\
\text { in SSC, or } \\
\text { rooming-in. } \\
* \text { Small sample } \\
\text { size } \\
* \text { Risk for } \\
\text { cultural bias } \\
* \text { Potential for } \\
\text { hawthorne } \\
\text { effect- the }\end{array}$ \\
\hline
\end{tabular}




\begin{tabular}{|c|c|c|c|c|c|}
\hline & & $\begin{array}{l}\text { immediately } \\
\text { after delivery } \\
\text { and then placed } \\
\text { under a radiant } \\
\text { warmer for a } \\
\text { brief physical } \\
\text { examination \& } \\
\text { routine early } \\
\text { medical } \\
\text { procedures were } \\
\text { performed. } \\
\text { Participants: } \\
\text { Pregnant women } \\
\text { without medical } \\
\text { complications, } \\
18 \text { years or } \\
\text { older, plan-ing } \\
\text { to BF for at least } \\
1 \text { month, } \\
\text { anticipating a } \\
\text { normal vaginal } \\
\text { delivery. }\end{array}$ & & & $\begin{array}{l}\text { authors felt that } \\
\text { the mothers in } \\
\text { this study were } \\
\text { highly motivated } \\
\text { to BF \& would } \\
\text { likely continue } \\
\text { to BF at least } \\
\text { one month } \\
\text { regardless of } \\
\text { problems faced, } \\
\text { knowing a } \\
\text { research } \\
\text { assistant would } \\
\text { be calling at one } \\
\text { month to assess } \\
\text { BF status. }\end{array}$ \\
\hline $\begin{array}{l}\text { Bramson et al. } \\
(2010)\end{array}$ & $\begin{array}{l}\text { AIM: } \\
* \text { To measure } \\
\text { the effect of } \\
\text { early SSC in the } \\
\text { first } 3 \text { hours of } \\
\text { life on exclusive } \\
\text { breastfeeding } \\
\text { during the } \\
\text { maternity stay. } \\
* \text { To examine a } \\
\text { possible dose- } \\
\text { response } \\
\text { relationship } \\
\text { between early } \\
\text { SSC \& EBF. }\end{array}$ & $\begin{array}{l}\text { Prospective } \\
\text { cohort study } \\
\mathrm{N}=21,842 \\
\text { mother-infant } \\
\text { pairs } \\
\mathrm{n}=16,970 \text { SSC } \\
\mathrm{n}=4,872 \text { no } \\
\text { SSC } \\
\text { Data: } \\
\text { *Where? San } \\
\text { Bernadino \& } \\
\text { Riverside } \\
\text { counties, 19 } \\
\text { Calif. Perinatal } \\
\text { Service (PSN) } \\
\text { Hospitals } \\
\text { Intervention } \\
\text { group: Mother \& } \\
\text { infant (M-I) } \\
\text { pairs who } \\
\text { experienced SSC } \\
\text { Control group: }\end{array}$ & $\begin{array}{l}\text { Independent } \\
\text { Variables: } \\
\text { * The duration } \\
\text { of early SSC } \\
\text { *The planned } \\
\text { amount \& } \\
\text { intention to BF. } \\
\text { Dependent } \\
\text { Variables: } \\
\text { * exclusive BF } \\
\text { Instrument: } \\
\text { * PSN data } \\
\text { collection } \\
\text { measurement } \\
\text { tool developed } \\
\text { in-house. Same } \\
\text { instrument used } \\
\text { in each of the } 19 \\
\text { hospitals, } \\
\text { applied mother's } \\
\text { medical record. }\end{array}$ & $\begin{array}{l}\text { Results: } \\
* \text { A dose- } \\
\text { response } \\
\text { relationship } \\
\text { between SSC \& } \\
\text { EBF was } \\
\text { demon-strated. } \\
\text { EBF was higher } \\
\text { in mothers who } \\
\text { experienced SSC } \\
\text { for } 1 \text { to } 15 \\
\text { minutes odds } \\
\text { ratio [OR] } \\
1.376 ; 95 \% \\
\text { confidence } \\
\text { interval [CI], } \\
1.189-1.593), 16 \\
\text { to } 30 \text { minutes } \\
\text { (OR } 1.665 ; 95 \% \\
\text { CI, 1.468- } \\
1.888), 31 \text { to } 59 \\
\text { minutes (OR } \\
2.357 ; 95 \% \text { CI, }\end{array}$ & $\begin{array}{l}\text { Strengths: } \\
\text { * Diverse } \\
\text { population } \\
\text { * } 198 \text { sites } \\
\text { * Large sample } \\
\text { size, \& a well- } \\
\text { designed } \\
\text { prospective } \\
\text { cohort study } \\
\text { * Sensitivity to } \\
\text { measure } \\
\text { variables that } \\
\text { could be } \\
\text { confounders that } \\
\text { interfere with } \\
\text { BF success (ex: } \\
\text { the mother's } \\
\text { intention to } \\
\text { breastfeed, } \\
\text { medication } \\
\text { received during } \\
\text { labor \& delivery, } \\
\text { \& cesarean }\end{array}$ \\
\hline
\end{tabular}




\begin{tabular}{|c|c|c|c|c|c|}
\hline & & $\begin{array}{l}\text { Reference group } \\
\text { was the M-I } \\
\text { pairs who did } \\
\text { not experience } \\
\text { SSC } \\
\text { Participants: } \\
\text { Mothers who } \\
\text { delivered a } \\
\text { healthy singleton } \\
\text { infant } \\
\text { (gestational age } \\
37-40 \text { weeks) } \\
\text { and were not } \\
\text { separated from } \\
\text { their infant for } \\
\text { more than } 1 \text { hour } \\
\text { during the } \\
\text { mother's } \\
\text { maternity } \\
\text { hospital stay. }\end{array}$ & & $\begin{array}{l}2.061-2.695) \text {, } \\
\text { and more than } 1 \\
\text { hour (OR 3.145; } \\
95 \% \text { CI, 2.905- } \\
3.405) \text {. }\end{array}$ & $\begin{array}{l}\text { delivery). } \\
\text { * Evidence from } \\
\text { other sources is } \\
\text { used to } \\
\text { demonstrate that } \\
\text { the method of } \\
\text { outcome } \\
\text { assessment is } \\
\text { valid and } \\
\text { reliable. There } \\
\text { was an attempt } \\
\text { to validate infant } \\
\text { feeding method } \\
\text { by comparing it } \\
\text { with the data } \\
\text { collected in the } \\
\text { 2006 CA NB } \\
\text { Screening } \\
\text { Program. } \\
\text { Limitations: } \\
* \text { No blinding, } \\
\text { no } \\
\text { randomization } \\
* \text { Measurement } \\
\text { of short } \\
\text { duration. }\end{array}$ \\
\hline $\begin{array}{l}\text { Mikiel-Kostyra } \\
\text { et al, } 2002\end{array}$ & $\begin{array}{l}\text { AIMS: } \\
\text {-To evaluate the } \\
\text { influence of } \\
\text { early skin-to- } \\
\text { skin care (SSC) } \\
\text { at birth on } \\
\text { exclusive breast- } \\
\text { feeding (EBF) } \\
\text { duration. }\end{array}$ & $\begin{array}{l}\text { Prospective } \\
\text { Cohort Design } \\
\mathrm{N}=11,973 \\
\mathrm{n}=1,020 \text { SSC } \\
\mathrm{n}=230 \text { no SSC } \\
\text { Data: } \\
\text { Where? Poland, } \\
\text { National Survey } \\
\text { of Maternity } \\
\text { Hospital } \\
\text { Practices } \\
\text { Intervention } \\
\text { group: } \\
\text { SSC a procedure } \\
\text { after delivery, } \\
\text { the infant is } \\
\text { placed on the }\end{array}$ & $\begin{array}{l}\text { Independent } \\
\text { Variable } \\
* \text { SSC lasting } \\
\text { greater than } 20 \\
\text { minutes } \\
\text { *SSC lasting } \\
\text { less than } 20 \\
\text { minutes } \\
\text { *No SSC after } \\
\text { birth } \\
\text { Dependent } \\
\text { Variables: } \\
\text { * EBF duration } \\
\text { * Overall BF } \\
\text { duration } \\
\text { Instrument: } \\
* \text { Standardized }\end{array}$ & $\begin{array}{l}\text { Results; } \\
* \text { SSC } \\
\text { significantly } \\
\text { increased mean } \\
\text { duration of EBF } \\
\text { by } 0.39 \text { months } \\
\text { and overall BF } \\
\text { duration by } 1.43 \\
\text { months. } \\
* \text { Infants kept } \\
\text { with their } \\
\text { mothers for at } \\
\text { least } 20 \text { minutes } \\
\text { were EBF for } \\
1.35 \text { months } \\
\text { longer and } \\
\text { weaned } 2.10 \\
\text { months later }\end{array}$ & $\begin{array}{l}\text { Strengths: } \\
* \text { Large sample } \\
\text { size, a well- } \\
\text { designed } \\
\text { prospective } \\
\text { cohort study. } \\
\text { * Randomization } \\
\text { of the initial } \\
\text { subset of healthy } \\
\text { newborns by } \\
\text { systematic } \\
\text { sampling of } \\
\text { every fifth case. } \\
* \text { Power analysis } \\
\text { based on sample } \\
\text { size } \\
\text { Limitations: }\end{array}$ \\
\hline
\end{tabular}




\begin{tabular}{|c|c|c|c|c|c|}
\hline & & $\begin{array}{l}\text { mother in direct } \\
\text { body contact. } \\
\text { Control group: } \\
* \text { Infants } \\
\text { received no SSC } \\
\text { care after birth } \\
* \text { Newborns, } \\
\text { gestational age } \\
\geq 37 \text { weeks, a } \\
\text { birth weight } \\
\geq 2500 \text { grams, } \\
\text { free of major } \\
\text { neonatal health } \\
\text { problems and } \\
\text { discharged at } 2- \\
15 \text { d after birth. }\end{array}$ & $\begin{array}{l}\text { questionnaire } \\
\text { measuring the } \\
\text { occurrence of } \\
\text { SSC, time of } \\
\text { initiation \& } \\
\text { duration of BF } \\
\text { over } 36 \text { months. }\end{array}$ & $\begin{array}{l}\text { than those who } \\
\text { had no SSC after } \\
\text { birth. } \\
\text { * SSC after birth } \\
\text { significantly } \\
\text { coexisted with } \\
\text { other hospital } \\
\text { practices } \\
\text { supportive to } \\
\text { BF: rooming-in } \\
\text { without } \\
\text { separation } \\
\text { longer than } 1 \text { in } \\
24 \text { hours } \\
\text { [relative risk } \\
\text { (RR) = 3.18, } \\
95 \% \text { confidence } \\
\text { interval (95\% } \\
\text { CI): } 2.34-4.31] \\
\text { and first BF } \\
\text { within } 2 \text { hours } \\
\text { after birth (RR = } \\
2.94,95 \% \text { CI: } \\
2.36-3.67) \text {. }\end{array}$ & $\begin{array}{l}\text { * Convenience } \\
\text { sample } \\
* \text { Cultural bias } \\
\text { Polish maternity } \\
\text { wards. } \\
\text { * No available } \\
\text { information } \\
\text { regarding } \\
\text { validity and } \\
\text { reliability of the } \\
\text { "standardized } \\
\text { questionnaire" }\end{array}$ \\
\hline $\begin{array}{l}\text { Defrisco et al, } \\
2011\end{array}$ & $\begin{array}{l}\text { AIMS: } \\
* \text { To determine } \\
\text { factors } \\
\text { associated with } \\
\text { exclusive } \\
\text { breastfeeding } \\
\text { (EBF) following } \\
\text { hospital } \\
\text { discharge at } 2 \\
\text { and } 4 \text { weeks. }\end{array}$ & $\begin{array}{l}\text { Descriptive } \\
\text { Survey Design } \\
\text { N=113, mothers } \\
\text { who experienced } \\
\text { SSC \& BF at } \\
\text { discharge } \\
\text { Data: } \\
\text { Where? A large } \\
\text { urban academic } \\
\text { medical center } \\
\text { with } 4.600 \text { births } \\
\text { annually } \\
\text { Data collection: } \\
\text { Convenience } \\
\text { sample of } \\
\text { mothers who BF } \\
\text { in the first hour } \\
\text { after birth (with } \\
\text { SSC) and who } \\
\text { continued to BF }\end{array}$ & $\begin{array}{l}\text { Independent } \\
\text { Variable: } \\
\text { * Initiation of } \\
\text { BF \& SSC after } \\
\text { delivery, in the } \\
\text { first hour \& BF } \\
\text { at discharge } \\
\text { Dependent } \\
\text { Variables: } \\
\text { * EBF \& amount } \\
\text { of BF at } 2 \text { \& } 4 \\
\text { weeks } \\
\text { Instrument: } \\
\text { * Survey } \\
\text { questionnaire } \\
\text { tool with } 28 \\
\text { items } \\
* \text { Two methods } \\
\text { of data }\end{array}$ & $\begin{array}{l}\text { Results: } \\
* \text { Mothers who } \\
\text { reported BF in } \\
\text { the first hour of } \\
\text { birth }(61.5 \%) \\
\text { were } \\
\text { significantly } \\
\text { more likely to be } \\
\text { EBF at } 2 \text { to } 4 \\
\text { weeks after } \\
\text { discharge } \\
\text { (x2=8.046 }\{1, \\
\text { n=96\}, } \\
\text { p=.005).This } \\
\text { was true for all } \\
\text { mothers, } \\
\text { whether the } \\
\text { mode of delivery } \\
\text { was vaginally or } \\
\text { by cesarean. No } \\
\text { other }\end{array}$ & $\begin{array}{l}\text { Strengths: } \\
\text { * Controlled for } \\
\text { confounders. } \\
\text { * Power analysis } \\
\text { based on sample } \\
\text { size } \\
\text { Limitations: } \\
\text { * Convenience } \\
\text { sample non- } \\
\text { experimental } \\
\text { design } \\
\text { * Selection bias, } \\
86 \% \text { were } \\
\text { experienced } \\
\text { breast feeders. } \\
* \text { Population } \\
\text { was } \\
\text { predominantly } \\
\text { middle class, } \\
\text { the sample was }\end{array}$ \\
\hline
\end{tabular}




\begin{tabular}{|c|c|c|c|c|c|}
\hline & & $\begin{array}{l}\text { at discharge } \\
\text { were contacted } \\
\text { by telephone at } 2 \\
\& 4 \text { weeks to } \\
\text { complete the } \\
\text { survey. }\end{array}$ & $\begin{array}{l}\text { collection } \\
\text { telephone } \\
\text { interview \& self- } \\
\text { directed online. }\end{array}$ & $\begin{array}{l}\text { variables were } \\
\text { signifi-cantly } \\
\text { associated with } \\
\text { EBF at } 2 \text { to } 4 \\
\text { weeks after } \\
\text { discharge. } \\
* 86 \% \text { of all } \\
\text { study } \\
\text { participants were } \\
\text { experienced } \\
\text { breast feeders. }\end{array}$ & self-selected. \\
\hline $\begin{array}{l}\text { Crenshaw et al, } \\
2012\end{array}$ & $\begin{array}{l}\text { AIMS: } \\
\text { * Aim 1: (Part } \\
\text { 1) describe the } \\
\text { rate of EBF with } \\
\text { early SSC after a } \\
\text { vaginal or } \\
\text { cesarean birth by } \\
\text { staff trained in } \\
\text { the SSC } \\
\text { PRECESS } \\
\text { Model. } \\
\text { * Aim 2: (Part } \\
\text { 2) sustainability } \\
\text { in monthly rates } \\
\text { of SSC EBF. }\end{array}$ & $\begin{array}{l}\text { Descriptive } \\
\text { Observational } \\
\text { Design (mixed } \\
\text { methods study } \\
\text { of an } \\
\text { intervention) } \\
\text { Part I- N=11 } \\
\text { Part II- N=300 } \\
\text { (over } 5 \text { months) } \\
\text {-n= 30 vaginal } \\
\text { monthly } \\
\text {-n= 30 } \\
\text { cesarean } \\
\text { monthly } \\
\text { (Total n = 60 per } \\
\text { month) } \\
\text { Data: } \\
\text { Where? } \\
\text { Nonprofit } \\
\text { private medical } \\
\text { center in } \\
\text { Southwest USA } \\
\text { Intervention } \\
* \text { Collection of } \\
\text { monthly data } \\
\text { rates to assess } \\
\text { EBF after } \\
\text { hospital } \\
\text { discharge } \\
\text { Participants: } 18 \\
\text { y/o and older, } \\
\text { pregnant women }\end{array}$ & $\begin{array}{l}\text { Independent } \\
\text { Variable: } \\
\text { * SSC within } \\
\text { one hour after } \\
\text { birth } \\
\text { * Vaginal birth } \\
\text { vs. cesarean } \\
\text { birth rates. } \\
\text { Dependent } \\
\text { Variables: } \\
\text {-* EBF, } \\
\text { exclusive } \\
\text { breastfeeding } \\
\text { rates at } \\
\text { discharge \& } \\
\text { monthly for } 5 \\
\text { months. } \\
\text { Instrument: } \\
* \text { Hospital } \\
\text { records } \\
\text { examining BF } \\
\text { patterns after } \\
\text { birth \& at } \\
\text { discharge }\end{array}$ & $\begin{array}{l}\text { Results: } \\
\text { Part I } \\
* \text { SSC increased } \\
\text { above baseline } \\
\text { by } 25 \% \\
\text { Part II- } \\
* \text { No significant } \\
\text { difference } \\
\text { (Pearson v2 = } \\
2.690, \text { df }=5, \mathrm{p} \\
=0.748 \text { ) in the } \\
\text { rate of EBF } \\
\text { across the } 6 \\
\text { study months. } \\
* \text { Overall rate of } \\
\text { SSC grew } \\
\text { monthly, the } \\
\text { baseline in July } \\
\text { was } 58 \% \text { \& by } \\
\text { Dec. was } 88 \% \text {. } \\
* \text { EBF monthly } \\
\text { rate ranged from } \\
49 \% \text { to } 54 \% \text {. }\end{array}$ & $\begin{array}{l}\text { Strengths: } \\
\text { * Large sample } \\
\text { *5 months } \\
\text { follow-up } \\
\text { * Internal } \\
\text { validity: an } \\
\text { effective model } \\
\text { for measuring } \\
\text { success with } \\
\text { SSC; the details } \\
\text { provided in the } 9 \\
\text { steps appear } \\
\text { more précised \& } \\
\text { accurate than } \\
\text { any measure } \\
\text { seen in the } \\
\text { evidence. } \\
\text { * Pilot program } \\
\text { in staff training: } \\
\text { SSC PRECESS } \\
\text { Model } \\
\text { Limitations: } \\
\text { * Convenience } \\
\text { sample non- } \\
\text { experimental } \\
\text { design } \\
\text { * Selection bias } \\
\text { * Cultural bias- } \\
\text { none of the } \\
\text { physicians or } \\
\text { nurse } \\
\text { anesthetists } \\
\text { participated. --- }\end{array}$ \\
\hline
\end{tabular}




\begin{tabular}{|c|c|c|c|c|c|}
\hline & & $\begin{array}{l}\text { admitted to the } \\
\text { labor and } \\
\text { delivery unit for } \\
\text { a vaginal birth or } \\
\text { scheduled } \\
\text { cesarean } \\
\text { surgery, who } \\
\text { agreed to } \\
\text { SSC after birth. } \\
\text { Healthy mothers } \\
\text { included. }\end{array}$ & & & $\begin{array}{l}* \text { Hawthorne } \\
\text { effect-the } \\
\text { experts present } \\
\text { at each birth } \\
\text { may have } \\
\text { affected the } \\
\text { results. }\end{array}$ \\
\hline $\begin{array}{l}\text { Moore et al, } \\
2012\end{array}$ & $\begin{array}{l}\text { AIM: } \\
\text { *to assess the } \\
\text { effects of early } \\
\text { SSC on } \\
\text { breastfeeding, } \\
\text { physiological } \\
\text { adaptation, and } \\
\text { behavior in } \\
\text { healthy mother- } \\
\text { newborn dyads. }\end{array}$ & $\begin{array}{l}\text { Design: } \\
\text { *randomized } \\
\text { controlled trials } \\
\text { comparing early } \\
\text { SSC with usual } \\
\text { hospital care } \\
\text { *18 countries: } \\
\text { non \& } \\
\text { westernized } \\
\text { nations, incldng } \\
\text { US \& UK } \\
\text { *November } \\
2011 \\
\text { *34 RCTs } \\
* 2177 \text { mother- } \\
\text { infant dyads }\end{array}$ & $\begin{array}{l}\text { Method: } \\
\text { *quality of the } \\
\text { included studies } \\
\text { was mixed- } \\
\text { *many studies } \\
\text { did not provide } \\
\text { clear } \\
\text { information on } \\
\text { the way the that } \\
\text { the } \\
\text { randomization } \\
\text { sequence was } \\
\text { generated } \\
* \text { or on the } \\
\text { methods used to } \\
\text { conceal group } \\
\text { allocation when } \\
\text { randomized }\end{array}$ & $\begin{array}{l}\text { Results: } \\
* 13 \text { trials with } \\
702 \text { participants } \\
\text { included a } \\
\text { significantly } \\
\text { positive effect of } \\
\text { early SSC on } \\
\text { breastfeeding at } \\
\text { one to four } \\
\text { months: RR= } \\
1.27,95 \% \mathrm{CI} \\
1.06 \text { to } 1.53 \text {. } \\
* 7 \text { trials with } \\
324 \text { participants- } \\
\text { SSC increased } \\
\text { breastfeeding } \\
\text { duration - } \\
\text { without } \\
\text { significance } \\
\text { (mean difference } \\
\text { of } 42.55 \text { days, } \\
95 \% \mathrm{CI}-1.69 \text { to } \\
86.79, \mathrm{P}=0.06 \text { ). }\end{array}$ & $\begin{array}{l}\text { Strengths: level I } \\
\text { research, large } \\
\text { sample numbers } \\
\text { with combined } \\
\text { statistics, and } \\
\text { clear and } \\
\text { specific } \\
\text { recommendation } \\
\text { s. } \\
\text { Limitations: } \\
\text { mixed methods } \\
\text { with } \\
\text { heterogeneity, } \\
\text { and variations in } \\
\text { implementation } \\
\text { and outcomes } \\
\text { related to the } \\
\text { intervention } \\
\text { Direction is } \\
\text { positive- authors } \\
\text { concluded that } \\
\text { SSC appears to } \\
\text { benefit } \\
\text { breastfeeding } \\
\text { outcomes and } \\
\text { there are no } \\
\text { short or long- } \\
\text { term negative } \\
\text { effects. }\end{array}$ \\
\hline $\begin{array}{l}\text { Linares et al, } \\
2016\end{array}$ & $\begin{array}{l}\text { AIMS: } \\
* \text { to evaluate the }\end{array}$ & $\begin{array}{l}\text { Design: } \\
\text { *longitudinal }\end{array}$ & $\begin{array}{l}\text { Data Analysis: } \\
\text { *to assess the }\end{array}$ & $\begin{array}{l}\text { Results: } \\
* \text { participation in }\end{array}$ & $\begin{array}{l}\text { Strengths: } \\
\text { bivariate }\end{array}$ \\
\hline
\end{tabular}




\begin{tabular}{|c|c|c|c|c|c|}
\hline & $\begin{array}{l}\text { influence } \\
\text { of early SSC on } \\
\text { initiation \& } \\
\text { sustained EBF at } \\
1 \text { month } \\
\text { postpartum } \\
\text { * to understand } \\
\text { underlying } \\
\text { healthcare } \\
\text { disparities of a } \\
\text { vulnerable } \\
\text { population group }\end{array}$ & 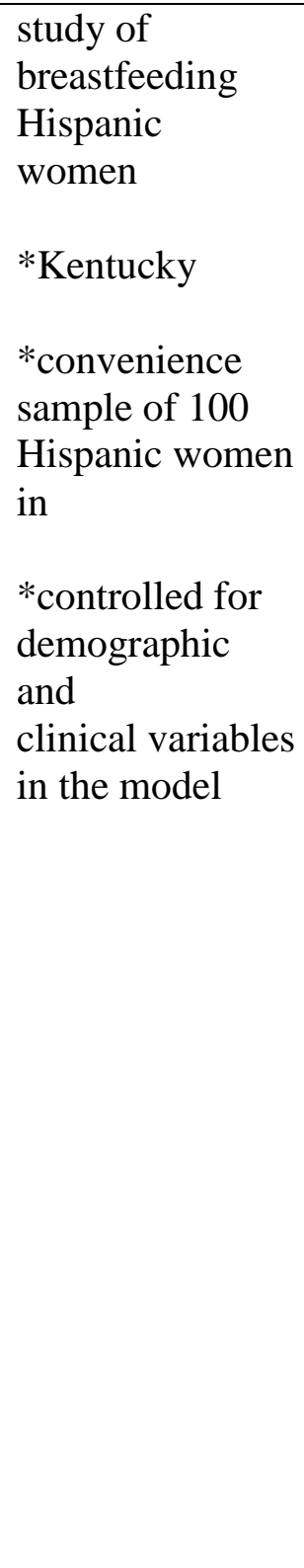 & $\begin{array}{l}\text { relationship } \\
\text { between SSC } \\
\text { and EBF over } \\
\text { time } \\
\text { *used the } \\
\text { generalized } \\
\text { estimating } \\
\text { equations (GEE) } \\
\text { model for binary } \\
\text { outcomes } \\
\text { *a repeated } \\
\text { measures model } \\
\text { analyzed EBF } \\
\text { status at } \\
\text { discharge and } 1 \\
\text { month } \\
\text { post-discharge }\end{array}$ & $\begin{array}{l}\text { early SSC- } \\
\text { associated with a } \\
\text { greater than } \\
\text { sevenfold } \\
\text { increase in the } \\
\text { odds of EBF at } \\
\text { discharge (p = } \\
.005) \\
\text { *not predictive } \\
\text { of EBF at } 1 \\
\text { month post- } \\
\text { discharge (p = } \\
.7 \text { ) } \\
\text { *descriptive } \\
\text { statistics chi } \\
\text { square, } \\
\text { independent t- } \\
\text { tests } \\
\text { *early SSC } \\
\text { group-more } \\
\text { likely to be EBF } \\
\text { at discharge } \\
\text { from maternity } \\
\text { stay versus } \\
\text { dyads not } \\
\text { experiencing } \\
\text { early SSC. }\end{array}$ & $\begin{array}{l}\text { analyses } \\
\text { examining the } \\
\text { association, well } \\
\text { conducted } \\
\text { research, two- } \\
\text { third of the } \\
\text { group women } \\
\text { practiced early } \\
\text { SSC } \\
\text { Limitations: } \\
\text { convenience } \\
\text { sample, small } \\
\text { study, reasons } \\
\text { for not } \\
\text { practicing SSC } \\
\text { were not } \\
\text { documented in } \\
\text { some of the } \\
\text { infant charts } \\
\text { Direction: } \\
\text { younger } \\
\text { maternal age and } \\
\text { increased } \\
\text { prenatal infant } \\
\text { feeding intention } \\
\text { may be } \\
\text { associated with } \\
\text { increased } \\
\text { likelihood of } \\
\text { EBF across both } \\
\text { time points }\end{array}$ \\
\hline $\begin{array}{l}\text { Anderzen- } \\
\text { Carlsson et al, } \\
2014 \quad \text { Part } 1\end{array}$ & $\begin{array}{l}\text { AIM: } \\
\text { To describe } \\
\text { parental } \\
\text { experiences of } \\
\text { providing skin- } \\
\text { to-skin care } \\
\text { (SSC) to their } \\
\text { newborn infants. }\end{array}$ & $\begin{array}{l}\text { Design: } \\
* \text { part I of a } \\
\text { meta-study } \\
\text { exploring } \\
\text { parental } \\
\text { experiences \& } \\
\text { SSC } \\
\text { *first qualitative } \\
\text { systematic } \\
\text { review regarding } \\
\text { parental }\end{array}$ & $\begin{array}{l}\text { Data Collection: } \\
\text { *four databases } \\
\text { were searched, } \\
\text { without year or } \\
\text { language } \\
\text { limitations, up } \\
\text { until December } \\
2013 \\
\text { *manual } \\
\text { searches per- } \\
\text { formed in } \\
\text { reference lists \& }\end{array}$ & $\begin{array}{l}\text { Results: } \\
\text { Two themes } \\
\text { emerged: } \\
\text { *a restoring } \\
\text { experience *an } \\
\text { energy-draining } \\
\text { experience. }\end{array}$ & $\begin{array}{l}\text { Strengths: } \\
* \text { well conducted } \\
\text { qualitative } \\
\text { research } \\
\text { * birth stories are } \\
\text { valuable to } \\
\text { balance the } \\
\text { rigors of } \\
\text { statistical } \\
\text { research } \\
\text { Limitations: }\end{array}$ \\
\hline
\end{tabular}




\begin{tabular}{|c|c|c|c|c|c|}
\hline & & $\begin{array}{l}\text { experiences \& } \\
\text { SSC } \\
* \text { systematic and } \\
\text { manual searches } \\
\text { led to the } \\
\text { inclusion of } 29 \\
\text { original } \\
\text { qualitative } \\
\text { papers from } 9 \\
\text { countries } \\
\text { *401 mothers } \\
\text { and } 94 \text { fathers. } \\
\text { *Sweden } \\
\text { Level 5: } \\
\text { systematic } \\
\text { review of } \\
\text { descriptive } \\
\text { qualitative } \\
\text { studies }\end{array}$ & $\begin{array}{l}\text { in a bibliography } \\
\text { of the topic. } \\
\text { *after a quality- } \\
\text { appraisal } \\
\text { process, data } \\
\text { from the original } \\
\text { articles were } \\
\text { extracted \& } \\
\text { analyzed using } \\
\text { qualitative } \\
\text { content analysis }\end{array}$ & & $\begin{array}{l}\text { Level } 5 \text { research } \\
\text { Direction: } \\
\text { *review has } \\
\text { added scientific } \\
\text { and systematic } \\
\text { knowledge about } \\
\text { parental } \\
\text { experiences of } \\
\text { providing SSC. } \\
\text { *further research } \\
\text { about fathers' } \\
\text { experiences is } \\
\text { recommended. }\end{array}$ \\
\hline $\begin{array}{l}\text { Anderzen- } \\
\text { Carlsson et al, } \\
2014 \quad \text { Part } 2\end{array}$ & $\begin{array}{l}\text { AIM: } \\
\text { To synthesize } \\
\text { and interpret } \\
\text { qualitative } \\
\text { research findings } \\
\text { focusing on } \\
\text { parental } \\
\text { experiences of } \\
\text { skin-to-skin care } \\
\text { (SSC) } \\
\text { for newborn } \\
\text { infants. }\end{array}$ & $\begin{array}{l}\text { Design: } \\
\text { *meta-synthesis } \\
\text { was guided by } \\
\text { the methodology } \\
\text { described by } \\
\text { Paterson and co- } \\
\text { workers. } \\
\text { *four databases } \\
\text { were searched, } \\
\text { without year or } \\
\text { language } \\
\text { limitations, up } \\
\text { until December } \\
2013 \\
\text { *manual } \\
\text { searches also } \\
\text { performed } \\
\text { *Sweden } \\
\text { Level 5: } \\
\text { systematic } \\
\text { review of } \\
\text { descriptive }\end{array}$ & $\begin{array}{l}\text { Data Collection: } \\
* \text { meta-synthesis } \\
\text { entails a meta- } \\
\text { data analysis, } \\
\text { analysis of meta- } \\
\text { method } \\
* \text { searches and } \\
\text { subsequent } \\
\text { quality appraisal } \\
\text { resulted in the } \\
\text { inclusion of } 29 \\
\text { original } \\
\text { qualitative } \\
\text { papers *9 } \\
\text { countries } \\
* 401 \text { mothers } \\
\text { and } 94 \text { fathers. }\end{array}$ & $\begin{array}{l}\text { Results: } \\
\text { *a theoretical } \\
\text { model of } \\
\text { becoming a } \\
\text { parent under } \\
\text { unfamiliar } \\
\text { circumstances } \\
\text { emerged. } \\
\text { *providing SSC } \\
\text { seems to be a } \\
\text { restorative as } \\
\text { well as an } \\
\text { energy-draining } \\
\text { experience } \\
\text { *supportive } \\
\text { environment has } \\
\text { been described } \\
\text { as facilitating } \\
\text { the restorative } \\
\text { experience } \\
\text { *challenges in } \\
\text { the environment } \\
\text { seem to make } \\
\text { the provision of }\end{array}$ & $\begin{array}{l}\text { Strengths: well } \\
\text { conducted } \\
\text { qualitative } \\
\text { research, birth } \\
\text { stories are } \\
\text { valuable to } \\
\text { balance the } \\
\text { rigors of } \\
\text { statistical } \\
\text { research } \\
\text { Limitations: } \\
\text { Level } 5 \text { research } \\
\text { Direction: } \\
\text { *SSC is a } \\
\text { family-including } \\
\& \text { important } \\
\text { health care } \\
\text { intervention } \\
\text { *the process of } \\
\text { becoming a } \\
\text { parent in this } \\
\text { specific situation }\end{array}$ \\
\hline
\end{tabular}




\begin{tabular}{|c|c|c|c|c|c|}
\hline & & $\begin{array}{l}\text { qualitative } \\
\text { studies }\end{array}$ & & $\begin{array}{l}\text { SSC energy- } \\
\text { draining for } \\
\text { parents } \\
\text { *a positive } \\
\text { experience with } \\
\text { SSC facilitates } \\
\text { the growth of } \\
\text { parental self- } \\
\text { esteem and } \\
\text { makes the } \\
\text { parents ready to } \\
\text { assume full } \\
\text { responsibility for } \\
\text { their child }\end{array}$ & $\begin{array}{l}\text { is influenced by } \\
\text { external factors } \\
\text { in three different } \\
\text { levels; family } \\
\text { and friends, } \\
\text { community, and } \\
\text { society at large } \\
\text { iptions of } \\
\text { ing SSC are } \\
\text { to what has } \\
\text { isly been } \\
\text { ped as the natural } \\
\text { sof becoming a } \\
\text { or father }\end{array}$ \\
\hline $\begin{array}{l}\text { Palmer et al, } \\
2010\end{array}$ & $\begin{array}{l}\text { AIM: to } \\
\text { describe } \\
\text { women's lived } \\
\text { experience } \\
\text { initiating } \\
\text { breastfeeding } \\
\text { within the } \\
\text { context of early } \\
\text { home discharge. }\end{array}$ & $\begin{array}{l}\text { Design: } \\
\text { *exploratory, } \\
\text { descriptive } \\
\text { \& consent from } \\
\text { the women } \\
\text { *reflective } \\
\text { lifeworld } \\
\text { research design } \\
\text { based on } \\
\text { phenomenologic } \\
\text { al philosophy } \\
\text { *Sweden } \\
\text { Level 6- single } \\
\text { descriptive } \\
\text { qualitative study }\end{array}$ & $\begin{array}{l}\text { Sample: } \\
8 \text { women, } \\
\text { * } 2 \text { primiparous, } \\
\text { * } 6 \text { multiparous } \\
\text { Process: } \\
\text { Interviewed } \\
\text { within } 2 \text { months } \\
\text { after birth. }\end{array}$ & $\begin{array}{l}\text { Results: } \\
\text { Essential } \\
\text { meaning } \\
\text { below from its } \\
\text { five constituents: } \\
\text { *fascination } \\
\text { in the first } \\
\text { encounter } \\
\text { *balancing the } \\
\text { unknown } \\
\text { *devoting } \\
\text { oneself and } \\
\text { enduring the } \\
\text { Situation } \\
\text { *seeking } \\
\text { confirmation in } \\
\text { the unique } \\
\text { *having the } \\
\text { entire } \\
\text { responsibility }\end{array}$ & $\begin{array}{l}\text { Strengths: } \\
\text { *well conducted } \\
\text { qualitative } \\
\text { research } \\
\text { *birth stories are } \\
\text { valuable to } \\
\text { balance the } \\
\text { rigors of } \\
\text { statistical } \\
\text { research } \\
\text { Limitations: } \\
\text { *Level 6 } \\
\text { research } \\
\text { *it was a } \\
\text { challenge for the } \\
\text { midwife } \\
\text { researcher to } \\
\text { separate her own } \\
\text { lived } \\
\text { experiences } \\
\text { from the } \\
\text { mothers in the } \\
\text { study } \\
\text { Direction: } \\
\text { Is positive- } \\
\text { *breastfeeding } \\
\text { interlaces } \\
\text { biological and } \\
\text { existential issues }\end{array}$ \\
\hline
\end{tabular}




\begin{tabular}{|c|c|c|c|c|c|}
\hline & & & & & $\begin{array}{l}\text { that cannot be } \\
\text { separated into } \\
\text { different parts } \\
\text { *it must be } \\
\text { regarded in its } \\
\text { wholeness with } \\
\text { lived experience } \\
\text { as essential }\end{array}$ \\
\hline $\begin{array}{l}\text { Finigan et al, } \\
2009\end{array}$ & $\begin{array}{l}\text { AIMS: } \\
\text { *to study } \\
\text { women's lived } \\
\text { experiences of } \\
\text { SSC with their } \\
\text { baby } \\
\text { immediately } \\
\text { after birth. } \\
\text { * to explore the } \\
\text { experiences } \\
\text { from the } \\
\text { women's own } \\
\text { perspective and } \\
\text { to clarify } \\
\text { whether or not } \\
\text { this is a 'mother- } \\
\text { friendly' } \\
\text { approach. }\end{array}$ & $\begin{array}{l}\text { Design: } \\
\text { *exploratory, } \\
\text { descriptive } \\
\text { \& consent from } \\
\text { the women. } \\
\text { *Transcripts } \\
\text { were returned to } \\
\text { the women for } \\
\text { verification. } \\
\text { *United } \\
\text { Kingdom } \\
\text { Level } 6 \text { - single } \\
\text { descriptive } \\
\text { qualitative study }\end{array}$ & $\begin{array}{l}\text { Sample: } \\
* 6 \text { multigravid } \\
\text { women } \\
\text { Process: } \\
\text { *Women kept an } \\
\text { audiotaped diary } \\
\text { for } 28 \text { days (end } \\
\text { of postnatal) } \\
\text { *Followed by an } \\
\text { in-depth } \\
\text { interview day } 28 \\
* \text { All interviews } \\
\& \text { audiotaped } \\
\text { diaries } \\
\text { transcribed } \\
\text { verbatim }\end{array}$ & $\begin{array}{l}\text { Results: } \\
\text { * women } \\
\text { verbalized } \\
\text { emotive and } \\
\text { visceral } \\
\text { language to } \\
\text { describe their } \\
\text { experiences SSC } \\
\text { with their babies } \\
\text { immediately } \\
\text { after birth } \\
\text { * Five themes } \\
\text { *discovered: } \\
\text { immediate } \\
\text { feelings of } \\
\text { 'bonding'; } \\
\text { stroking \& } \\
\text { touching } \\
\text { *description of } \\
\text { gazing coming } \\
\text { to know the } \\
\text { baby *described } \\
\text { a'natural, } \\
\text { instinctive' } \\
\text { behavior } \\
\text { *desiring not to } \\
\text { let go of the } \\
\text { baby }\end{array}$ & $\begin{array}{l}\text { Strengths: } \\
\text { *well conducted } \\
\text { qualitative } \\
\text { research } \\
\text { *birth stories are } \\
\text { valuable to } \\
\text { balance the } \\
\text { rigors of } \\
\text { statistical } \\
\text { research } \\
\text { Limitations: } \\
\text { Level } 6 \text { research } \\
\text { Direction: } \\
\text { The women } \\
\text { described: } \\
\text { *'instinctive' } \\
\text { feelings with } \\
\text { SSC } \\
\text { *the desire for a } \\
\text { longer period of } \\
\text { uninterrupted } \\
\text { skin-to-skin } \\
\text { contact. } \\
\text { *felt the baby } \\
\text { was a 'reward' } \\
\text { after the } \\
\text { challenges of } \\
\text { labor. } \\
\text { *the time was } \\
\text { described as } \\
\text { pleasurable \& an } \\
\text { important birth } \\
\text { memory }\end{array}$ \\
\hline
\end{tabular}


Table 2

Demographics as Means and Standard Deviations

\begin{tabular}{|c|c|c|c|c|c|c|}
\hline \multirow[t]{2}{*}{ Characteristic } & \multicolumn{2}{|c|}{$\begin{array}{l}\text { SCC Group } \\
(\mathrm{n}=34) \\
\end{array}$} & \multicolumn{2}{|c|}{$\begin{array}{c}\text { Comparison Group } \\
(\mathrm{n}=21)\end{array}$} & \multicolumn{2}{|c|}{$\begin{array}{l}\text { Total } \\
(\mathrm{n}=55)\end{array}$} \\
\hline & M & SD & M & SD & $\bar{M}$ & $\overline{\mathrm{SD}}$ \\
\hline $\begin{array}{c}\text { Age at birth } \\
\text { in years }\end{array}$ & 24.47 & 5.310 & 23.95 & 4.717 & 24.27 & 5.053 \\
\hline $\begin{array}{l}\text { Last grade } \\
\text { completed in school }\end{array}$ & 14.21 & 2.487 & 13.24 & 1.609 & 13.84 & 2.033 \\
\hline Gravidity & 1.71 & 1.360 & 1.62 & 0.740 & 1.68 & 2.1 \\
\hline Parity & 1.41 & 0.783 & 1.29 & 0.561 & 1.37 & 0.672 \\
\hline Term in weeks & 39.21 & 0.808 & 38.81 & 0.602 & 39.06 & 0.705 \\
\hline $\begin{array}{l}\text { Number of children } \\
\text { breastfed }\end{array}$ & 1.21 & 0.410 & 1.24 & 0.539 & 1.23 & 0.475 \\
\hline $\begin{array}{l}\text { Maternity leave } \\
\text { in months }\end{array}$ & 1.50 & 0.508 & 1.43 & 0.507 & 1.47 & 0.508 \\
\hline $\begin{array}{l}\text { Total time of } \\
\text { breastfeeding in } \\
\text { months } *\end{array}$ & 5.52 & 6.187 & 8.012 & 9.897 & 6.48 & 8.042 \\
\hline
\end{tabular}

Note. No statistically significant differences were found between the SCC and comparison groups.

*Eleven in the SSC $(n=23)$ had not weaned the baby from breastfeeding at the time of the interview. 
Table 2A

Demographics as a Percentage

\begin{tabular}{|c|c|c|c|}
\hline Characteristic & $\begin{array}{l}\text { SCC Group } \\
*(n=34)\end{array}$ & $\begin{array}{l}\text { Comparison } \\
(\mathrm{n}=21)\end{array}$ & $\begin{array}{l}\text { Total } \\
(\mathrm{n}=55)\end{array}$ \\
\hline (\% yes) & $\%$ & $\%$ & $\%$ \\
\hline \multicolumn{4}{|l|}{ Race } \\
\hline Caucasian & $94 \%$ & $95 \%$ & $94.5 \%$ \\
\hline Attended breastfeeding class & $32 \%$ & $10 \%$ & $21 \%$ \\
\hline Maternity leave & $50 \%$ & $43 \%$ & $46.5 \%$ \\
\hline $\begin{array}{l}\text { Health problems with } \\
\text { pregnancy or postpartum }\end{array}$ & $18 \%$ & $33 \%$ & $25.5 \%$ \\
\hline $\begin{array}{l}\text { General health problems } \\
\text { not pregnant }\end{array}$ & $6 \%$ & $14 \%$ & $10 \%$ \\
\hline $\begin{array}{l}\text { Achieved desired length } \\
\text { of breastfeeding } *\end{array}$ & $30 \%$ & $33 \%$ & $31.5 \%$ \\
\hline $\begin{array}{l}\text { Health problems } \\
\text { with breastfeeding }\end{array}$ & $44 \%$ & $48 \%$ & $46 \%$ \\
\hline $\begin{array}{l}\text { Mother felt supported } \\
\text { with breastfeeding }\end{array}$ & $97 \%$ & $100 \%$ & $98.5 \%$ \\
\hline
\end{tabular}

Note. No statistically significant differences were found between the SCC and comparison groups.

*Eleven in the SSC $(n=23)$ had not weaned the baby from breastfeeding at the time of the interview. 
Table 3

Duration of Breastfeeding Rates at 6 weeks

\begin{tabular}{|c|c|c|c|c|c|}
\hline & & & \multicolumn{2}{|c|}{ Received SSC/kc per policy } & \multirow[b]{2}{*}{ Total } \\
\hline & & & No & Yes & \\
\hline \multirow[t]{8}{*}{ Length of BF 6 weeks } & NO & Count & 8 & 6 & 14 \\
\hline & & $\begin{array}{l}\% \text { within Length of BF } 6 \\
\text { weeks }\end{array}$ & $57.1 \%$ & $42.9 \%$ & $100.0 \%$ \\
\hline & & $\begin{array}{l}\% \text { within Received SSC/kc } \\
\text { per policy }\end{array}$ & $38.1 \%$ & $17.6 \%$ & $25.5 \%$ \\
\hline & & $\%$ of Total & $14.5 \%$ & $10.9 \%$ & $25.5 \%$ \\
\hline & YES & Count & 13 & 28 & 41 \\
\hline & & $\begin{array}{l}\% \text { within Length of BF } 6 \\
\text { weeks }\end{array}$ & $31.7 \%$ & $68.3 \%$ & $100.0 \%$ \\
\hline & & $\begin{array}{l}\% \text { within Received SSC/kc } \\
\text { per policy }\end{array}$ & $61.9 \%$ & $82.4 \%$ & $74.5 \%$ \\
\hline & & $\%$ of Total & $23.6 \%$ & $50.9 \%$ & $74.5 \%$ \\
\hline \multirow[t]{4}{*}{ Total } & & Count & 21 & 34 & 55 \\
\hline & & $\begin{array}{l}\% \text { within Length of BF } 6 \\
\text { weeks }\end{array}$ & $38.2 \%$ & $61.8 \%$ & $100.0 \%$ \\
\hline & & $\begin{array}{l}\% \text { within Received SSC/kc } \\
\text { per policy }\end{array}$ & $100.0 \%$ & $100.0 \%$ & $100.0 \%$ \\
\hline & & $\%$ of Total & $38.2 \%$ & $61.8 \%$ & $100.0 \%$ \\
\hline
\end{tabular}

\section{Duration of Breastfeeding Chi-Square Tests at 6 weeks}

\begin{tabular}{|c|c|c|c|c|c|}
\hline & Value & $\mathrm{df}$ & $\begin{array}{c}\text { Asymptotic } \\
\text { Significance (2- } \\
\text { sided) } \\
\end{array}$ & $\begin{array}{c}\text { Exact Sig. (2- } \\
\text { sided) }\end{array}$ & $\begin{array}{c}\text { Exact Sig. (1- } \\
\text { sided) }\end{array}$ \\
\hline Pearson Chi-Square & $2.861^{\mathrm{a}}$ & 1 & 0.091 & & \\
\hline Continuity Correction $^{\mathrm{b}}$ & 1.884 & 1 & 0.170 & & \\
\hline Likelihood Ratio & 2.802 & 1 & 0.094 & & \\
\hline Fisher's Exact Test & & & & 0.117 & 0.086 \\
\hline Linear-by-Linear Association & 2.809 & 1 & 0.094 & & \\
\hline $\mathrm{N}$ of Valid Cases & 55 & & & & \\
\hline
\end{tabular}

a. 0 cells $(.0 \%)$ have expected count less than 5 . The minimum expected count is 5.35 .

b. Computed only for a $2 \times 2$ table 
Table 4

Duration of Breastfeeding Rates at 3 months

\begin{tabular}{|c|c|c|c|c|c|}
\hline & & & \multicolumn{2}{|c|}{ Received SSC/kc per policy } & \multirow[b]{2}{*}{ Total } \\
\hline & & & No & Yes & \\
\hline \multirow[t]{8}{*}{ Length of BF 3 months } & \multirow[t]{4}{*}{ NO } & Count & 10 & 9 & 19 \\
\hline & & $\begin{array}{l}\% \text { within Length of BF } 3 \\
\text { months }\end{array}$ & $52.6 \%$ & $47.4 \%$ & $100.0 \%$ \\
\hline & & $\begin{array}{l}\% \text { within Received SSC/kc } \\
\text { per policy }\end{array}$ & $47.6 \%$ & $26.5 \%$ & $34.5 \%$ \\
\hline & & $\%$ of Total & $18.2 \%$ & $16.4 \%$ & $34.5 \%$ \\
\hline & \multirow[t]{4}{*}{ YES } & Count & 11 & 25 & 36 \\
\hline & & $\begin{array}{l}\% \text { within Length of BF } 3 \\
\text { months }\end{array}$ & $30.6 \%$ & $69.4 \%$ & $100.0 \%$ \\
\hline & & $\begin{array}{l}\% \text { within Received SSC/kc } \\
\text { per policy }\end{array}$ & $52.4 \%$ & $73.5 \%$ & $65.5 \%$ \\
\hline & & $\%$ of Total & $20.0 \%$ & $45.5 \%$ & $65.5 \%$ \\
\hline \multirow[t]{4}{*}{ Total } & & Count & 21 & 34 & 55 \\
\hline & & $\begin{array}{l}\% \text { within Length of BF } 3 \\
\text { months }\end{array}$ & $38.2 \%$ & $61.8 \%$ & $100.0 \%$ \\
\hline & & $\begin{array}{l}\% \text { within Received SSC/kc } \\
\text { per policy }\end{array}$ & $100.0 \%$ & $100.0 \%$ & $100.0 \%$ \\
\hline & & $\%$ of Total & $38.2 \%$ & $61.8 \%$ & $100.0 \%$ \\
\hline
\end{tabular}

\section{Duration of Breastfeeding Chi-Square Tests at 3 months}

\begin{tabular}{|c|c|c|c|c|c|}
\hline & Value & $\mathrm{df}$ & $\begin{array}{c}\text { Asymptotic } \\
\text { Significance (2- } \\
\text { sided) }\end{array}$ & $\begin{array}{c}\text { Exact Sig. (2- } \\
\text { sided) }\end{array}$ & $\begin{array}{c}\text { Exact Sig. (1- } \\
\text { sided) }\end{array}$ \\
\hline Pearson Chi-Square & $2.568^{\mathrm{a}}$ & 1 & 0.109 & & \\
\hline Continuity Correction $^{\mathrm{b}}$ & 1.718 & 1 & 0.190 & & \\
\hline Likelihood Ratio & 2.541 & 1 & 0.111 & & \\
\hline Fisher's Exact Test & & & & 0.147 & 0.095 \\
\hline Linear-by-Linear Association & 2.521 & 1 & 0.112 & & \\
\hline $\mathrm{N}$ of Valid Cases & 55 & & & & \\
\hline
\end{tabular}

a. 0 cells $(.0 \%)$ have expected count less than 5 .

b. Computed only for a $2 \times 2$ table 
Table 5

Duration of Breastfeeding Rates at 6 months

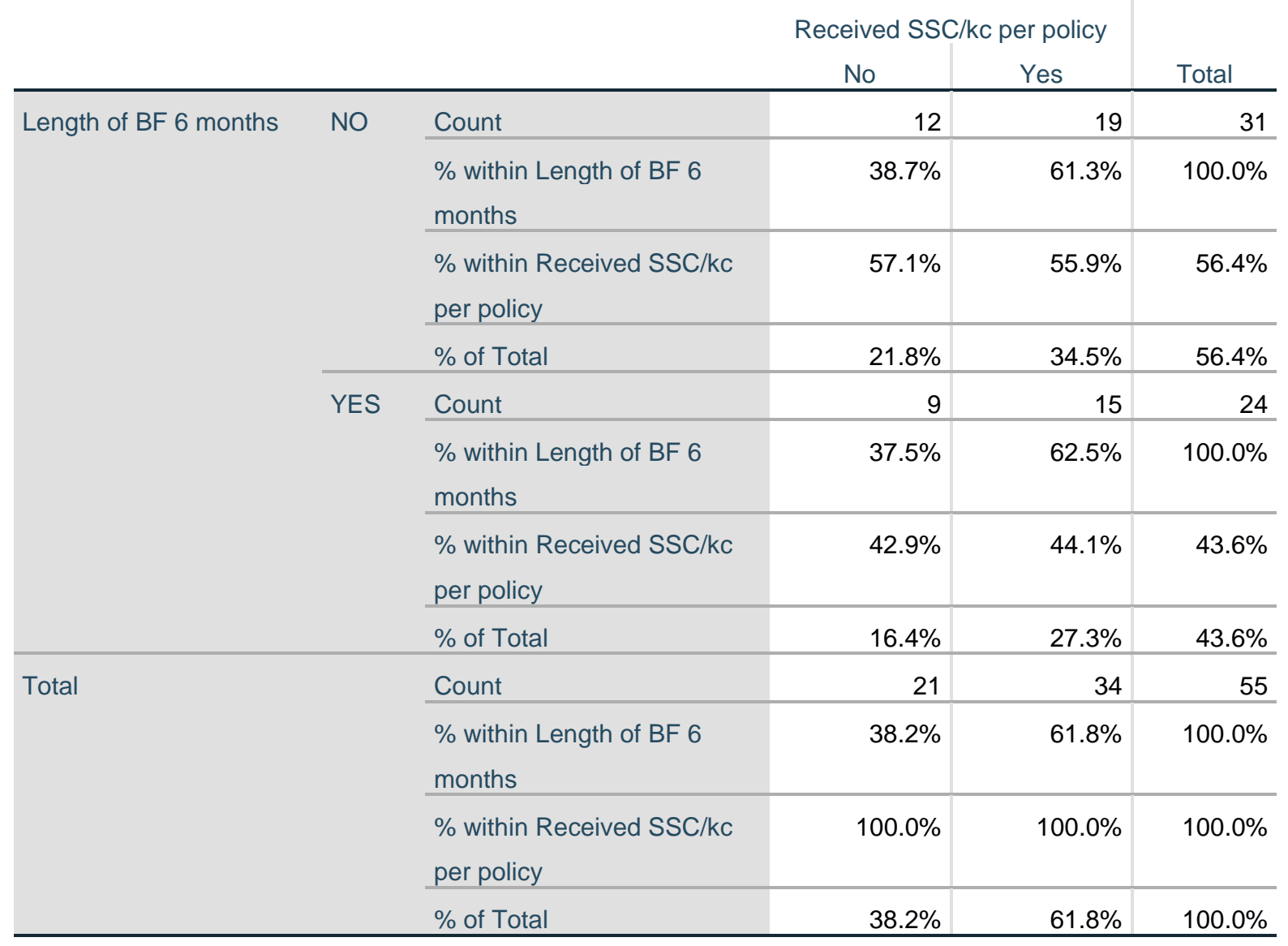

\section{Duration of Breastfeeding Chi-Square Tests at 6 months}

\begin{tabular}{|c|c|c|c|c|c|}
\hline & Value & $\mathrm{df}$ & $\begin{array}{c}\text { Asymptotic } \\
\text { Significance (2- } \\
\text { sided) } \\
\end{array}$ & $\begin{array}{c}\text { Exact Sig. (2- } \\
\text { sided) }\end{array}$ & $\begin{array}{c}\text { Exact Sig. (1- } \\
\text { sided) }\end{array}$ \\
\hline Pearson Chi-Square & $2.861^{\mathrm{a}}$ & 1 & 0.091 & & \\
\hline Continuity Correction $^{\mathrm{b}}$ & 1.884 & 1 & 0.170 & & \\
\hline Likelihood Ratio & 2.802 & 1 & 0.094 & & \\
\hline Fisher's Exact Test & & & & 0.117 & 0.086 \\
\hline Linear-by-Linear Association & 2.809 & 1 & 0.094 & & \\
\hline $\mathrm{N}$ of Valid Cases & 55 & & & & \\
\hline
\end{tabular}
a. 0 cells $(.0 \%)$ have expected count less than 5 .
b. Computed only for a $2 \times 2$ table 
Table 6

Exclusive Breastfeeding Rates at 6 weeks

\begin{tabular}{|c|c|c|c|c|c|}
\hline & & & \multicolumn{2}{|c|}{ Received SSC/kc per policy } & \multirow[b]{2}{*}{ Total } \\
\hline & & & No & Yes & \\
\hline \multirow[t]{8}{*}{ EBF for 6 weeks } & NO & Count & 9 & 9 & 18 \\
\hline & & $\%$ within EBF for 6 weeks & $50.0 \%$ & $50.0 \%$ & $100.0 \%$ \\
\hline & & $\begin{array}{l}\% \text { within Received SSC/kc } \\
\text { per policy }\end{array}$ & $42.9 \%$ & $26.5 \%$ & $32.7 \%$ \\
\hline & & $\%$ of Total & $16.4 \%$ & $16.4 \%$ & $32.7 \%$ \\
\hline & YES & Count & 12 & 25 & 37 \\
\hline & & $\%$ within EBF for 6 weeks & $32.4 \%$ & $67.6 \%$ & $100.0 \%$ \\
\hline & & $\begin{array}{l}\% \text { within Received SSC/kc } \\
\text { per policy }\end{array}$ & $57.1 \%$ & $73.5 \%$ & $67.3 \%$ \\
\hline & & $\%$ of Total & $21.8 \%$ & $45.5 \%$ & $67.3 \%$ \\
\hline \multirow[t]{4}{*}{ Total } & & Count & 21 & 34 & 55 \\
\hline & & $\%$ within EBF for 6 weeks & $38.2 \%$ & $61.8 \%$ & $100.0 \%$ \\
\hline & & $\begin{array}{l}\% \text { within Received SSC/kc } \\
\text { per policy }\end{array}$ & $100.0 \%$ & $100.0 \%$ & $100.0 \%$ \\
\hline & & $\%$ of Total & $38.2 \%$ & $61.8 \%$ & $100.0 \%$ \\
\hline
\end{tabular}

\section{Exclusive Breastfeeding Chi-Square Tests at 6 weeks}

\begin{tabular}{|c|c|c|c|c|c|}
\hline & Value & $\mathrm{df}$ & $\begin{array}{c}\text { Asymptotic } \\
\text { Significance (2- } \\
\text { sided) }\end{array}$ & $\begin{array}{c}\text { Exact Sig. (2- } \\
\text { sided) }\end{array}$ & $\begin{array}{c}\text { Exact Sig. (1- } \\
\text { sided) }\end{array}$ \\
\hline Pearson Chi-Square & $1.583^{\mathrm{a}}$ & 1 & 0.208 & & \\
\hline Continuity Correction $^{\mathrm{b}}$ & 0.926 & 1 & 0.336 & & \\
\hline Likelihood Ratio & 1.565 & 1 & 0.211 & & \\
\hline Fisher's Exact Test & & & & 0.246 & 0.168 \\
\hline Linear-by-Linear Association & 1.555 & 1 & 0.212 & & \\
\hline $\mathrm{N}$ of Valid Cases & 55 & & & & \\
\hline
\end{tabular}

a. 0 cells $(.0 \%)$ have expected count less than 5 . The minimum expected count is 6.87 .

b. Computed only for a $2 \times 2$ table 
Table 7

Exclusive Breastfeeding Rates at 3 months

\begin{tabular}{|c|c|c|c|c|c|}
\hline & & & \multicolumn{2}{|c|}{ Received SSC/kc per policy } & \multirow[b]{2}{*}{ Total } \\
\hline & & & No & Yes & \\
\hline \multirow[t]{8}{*}{ EBF for 3 months } & NO & Count & 10 & 12 & 22 \\
\hline & & $\%$ within EBF for 3 months & $45.5 \%$ & $54.5 \%$ & $100.0 \%$ \\
\hline & & $\begin{array}{l}\% \text { within Received SSC/kc } \\
\text { per policy }\end{array}$ & $47.6 \%$ & $35.3 \%$ & $40.0 \%$ \\
\hline & & $\%$ of Total & $18.2 \%$ & $21.8 \%$ & $40.0 \%$ \\
\hline & YES & Count & 11 & 22 & 33 \\
\hline & & $\%$ within EBF for 3 months & $33.3 \%$ & $66.7 \%$ & $100.0 \%$ \\
\hline & & $\begin{array}{l}\% \text { within Received SSC/kc } \\
\text { per policy }\end{array}$ & $52.4 \%$ & $64.7 \%$ & $60.0 \%$ \\
\hline & & $\%$ of Total & $20.0 \%$ & $40.0 \%$ & $60.0 \%$ \\
\hline \multirow[t]{4}{*}{ Total } & & Count & 21 & 34 & 55 \\
\hline & & $\%$ within EBF for 3 months & $38.2 \%$ & $61.8 \%$ & $100.0 \%$ \\
\hline & & $\begin{array}{l}\% \text { within Received SSC/kc } \\
\text { per policy }\end{array}$ & $100.0 \%$ & $100.0 \%$ & $100.0 \%$ \\
\hline & & $\%$ of Total & $38.2 \%$ & $61.8 \%$ & $100.0 \%$ \\
\hline
\end{tabular}

\section{Exclusive Breastfeeding Chi-Square Tests at 3 months}

\begin{tabular}{|c|c|c|c|c|c|}
\hline & Value & $\mathrm{df}$ & $\begin{array}{c}\text { Asymptotic } \\
\text { Significance (2- } \\
\text { sided) }\end{array}$ & $\begin{array}{c}\text { Exact Sig. (2- } \\
\text { sided) }\end{array}$ & $\begin{array}{c}\text { Exact Sig. (1- } \\
\text { sided) }\end{array}$ \\
\hline Pearson Chi-Square & $0.822^{\mathrm{a}}$ & 1 & 0.365 & & \\
\hline Continuity Correction $^{\mathrm{b}}$ & 0.388 & 1 & 0.533 & & \\
\hline Likelihood Ratio & 0.818 & 1 & 0.366 & & \\
\hline Fisher's Exact Test & & & & 0.407 & 0.266 \\
\hline Linear-by-Linear Association & 0.807 & 1 & 0.369 & & \\
\hline $\mathrm{N}$ of Valid Cases & 55 & & & & \\
\hline
\end{tabular}

a. 0 cells $(.0 \%)$ have expected count less than 5 . The minimum expected count is 8.40 .

b. Computed only for a $2 \times 2$ table 
Table 8

Exclusive Breastfeeding Rates at 6 months

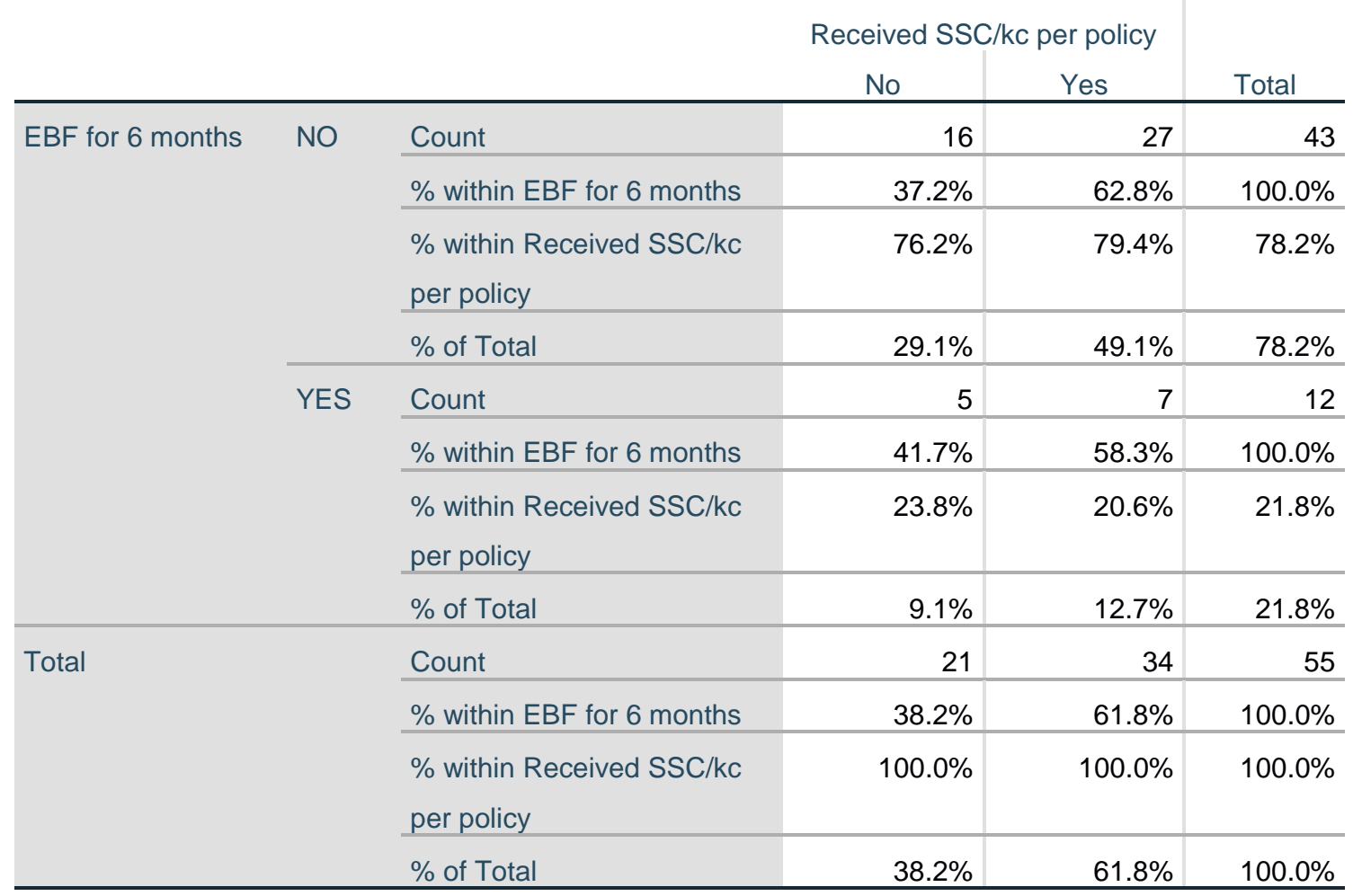

\section{Exclusive Breastfeeding Chi-Square Tests at 6 months}

\begin{tabular}{|c|c|c|c|c|c|}
\hline & Value & $\mathrm{df}$ & $\begin{array}{c}\text { Asymptotic } \\
\text { Significance (2- } \\
\text { sided) } \\
\end{array}$ & $\begin{array}{c}\text { Exact Sig. (2- } \\
\text { sided) }\end{array}$ & $\begin{array}{c}\text { Exact Sig. (1- } \\
\text { sided) }\end{array}$ \\
\hline Pearson Chi-Square & $0.079^{\mathrm{a}}$ & 1 & 0.779 & & \\
\hline Continuity Correction $^{\mathrm{b}}$ & 0.000 & 1 & 1.000 & & \\
\hline Likelihood Ratio & 0.078 & 1 & 0.780 & & \\
\hline Fisher's Exact Test & & & & 1.000 & 0.516 \\
\hline Linear-by-Linear Association & 0.078 & 1 & 0.781 & & \\
\hline $\mathrm{N}$ of Valid Cases & 55 & & & & \\
\hline
\end{tabular}

a. 1 cells (25.0\%) have expected count less than 5 . The minimum expected count is 4.58 .

b. Computed only for a $2 \times 2$ table 
Table 9 Qualitative Data: Most common words, phrases, themes

\begin{tabular}{|c|c|}
\hline $\begin{array}{l}\text { Survey Question: Do you have anything you would like to say about your birth, the skin-to- } \\
\text { skin experience, and the first memories of seeing and touching your child? }\end{array}$ & $\mathbf{N}=34$ \\
\hline Top Descriptors about SSC & Frequency \\
\hline It was the most amazing experience (awesome and exciting also used) & 7 \\
\hline I thought it was great & 5 \\
\hline It was just wonderful & 4 \\
\hline It was special and unique & 3 \\
\hline \multicolumn{2}{|l|}{ SSC Effects on Breastfeeding } \\
\hline It helped me get breastfeeding started & 7 \\
\hline It probably helped me breastfeed longer & 4 \\
\hline Ifeel like he breastfed faster & 2 \\
\hline \multicolumn{2}{|l|}{ SSC Effects on Bonding } \\
\hline It helped promote bonding ... ( $\quad 22$ included both bonding and breastfeeding) & 13 \\
\hline It made us a lot closer & 6 \\
\hline I couldn't have imagined it & 4 \\
\hline \multicolumn{2}{|l|}{ Unique Descriptors } \\
\hline \multicolumn{2}{|l|}{ I don't think that I would have bonded with him or breastfed as well without it } \\
\hline \multicolumn{2}{|l|}{ It made me feel relaxed and calmer to breastfeed, my husband also did better } \\
\hline \multicolumn{2}{|l|}{ A bond started right away and it helped us form a greater dependency together } \\
\hline \multicolumn{2}{|l|}{ It is the way that we are supposed to feel about our babies } \\
\hline \multicolumn{2}{|l|}{ Everyone should do skin-to-skin. It helped with breastfeeding and everything } \\
\hline \multicolumn{2}{|l|}{ The more contact you have with your child the more the bond grows } \\
\hline \multicolumn{2}{|l|}{ I wanted to breastfeed longer } \\
\hline \multicolumn{2}{|l|}{ I didn't feel so overwhelmed at first ... all the visitors didn't even bother me } \\
\hline \multicolumn{2}{|l|}{ It was the most amazing thing that I have ever been through in my life } \\
\hline $\begin{array}{l}\text { I would do it all over again. I immediately started my breast feeding and I didn't have any } \\
\text { complications }\end{array}$ & \\
\hline
\end{tabular}

